\title{
Climate Vulnerability Assessment of California Rangelands
}

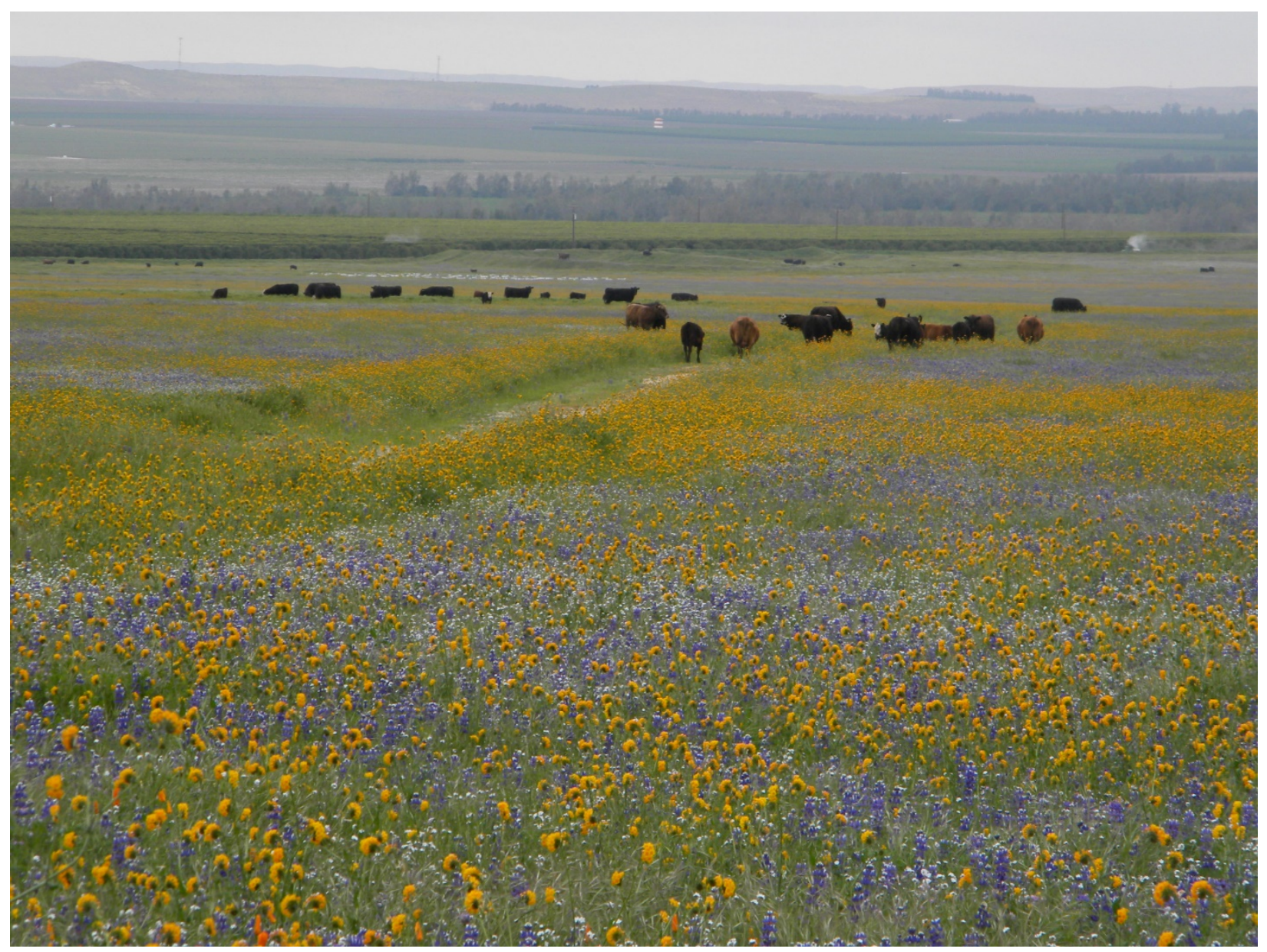

June 2018 


\author{
Authors: \\ Jennifer Balachowski, USDA California Climate Hub \\ Pelayo Alvarez, Consultant \\ Amber Kerr, University of California, Davis \\ Julian Reyes, USDA Southwest Climate Hub \\ Alexandros Xides, University of California, Davis \\ Hyeyeong Choe, University of California, Davis \\ Casey Peters, University of California, Davis \\ Joel Brown, USDA-NRCS Jornada Experimental Range \\ Leslie Roche, University of California, Davis
}

Suggested Citation: Balachowski, J., P. Alvarez, A. Kerr, J. Reyes, A. Xides, H. Choe, C.

Peters, J. Brown, and L. Roche. (2017). Climate Vulnerability Assessment of California

Rangelands. U.S. Department of Agriculture: 73.

Cover Photo: Tejon Ranch, Rebecca Wenk, 2010.

\title{
Contact:
}

USDA California Climate Hub, Agricultural Research Service

John Muir Institute of the Environment

One Shields Avenue

University of California

Davis, CA 95616 


\section{ACKnowledgements}

The USDA California Climate Hub is grateful for the contributions of the following individuals: Travis Averill (USDA-NASS) for helping interpret USDA livestock data; Ceci Dale-Cesmat (USDA-NRCS) for project development and review of early drafts; Lesa Eidman (Superior Farms) for expert advice on sheep and goats; Emile Elias (USDA-ARS) for hydrological expertise; Kelly Garbach (Point Blue Conservation) for thoughtful comments on the manuscript; Eleni Getachew (UC Davis) for manuscript formatting; Luana Kiger (USDANRCS) for project strategy and careful chapter reviews; John Lowrie (CA Natural Resources Agency) for advice during project inception; Dan Macon (UC Davis / Flying Mule Farm) for useful input on rancher adaptation strategies; Andrew McElrone (UC Davis) for project oversight and guidance; Jim Oltjen (UC Davis) for project development and careful review of several chapters; Steven Ostoja (USDA California Climate Hub) for project strategy, scheduling, and resources; Mark Schwartz (UC Davis) for staffing support, project coordination, and technical advice on climate modeling; Kerri Steenwerth (USDA-ARS) and Peter Stine (USDA-FS) for helping to build the project outline and author team; Darrel Sweet (CA Cattlemen's Association) for in-person conversations and practical input on early drafts; Jim Thorne (UC Davis) for staffing support and technical input on vegetation modeling and mapping; Rich Walker (CAL FIRE) for sharing findings from the Fire Resource and Assessment Program; and Dustin Ward (USDA-ARS) for assistance finalizing the manuscript. Any errors or omissions in this report remain the sole responsibility of the authors.

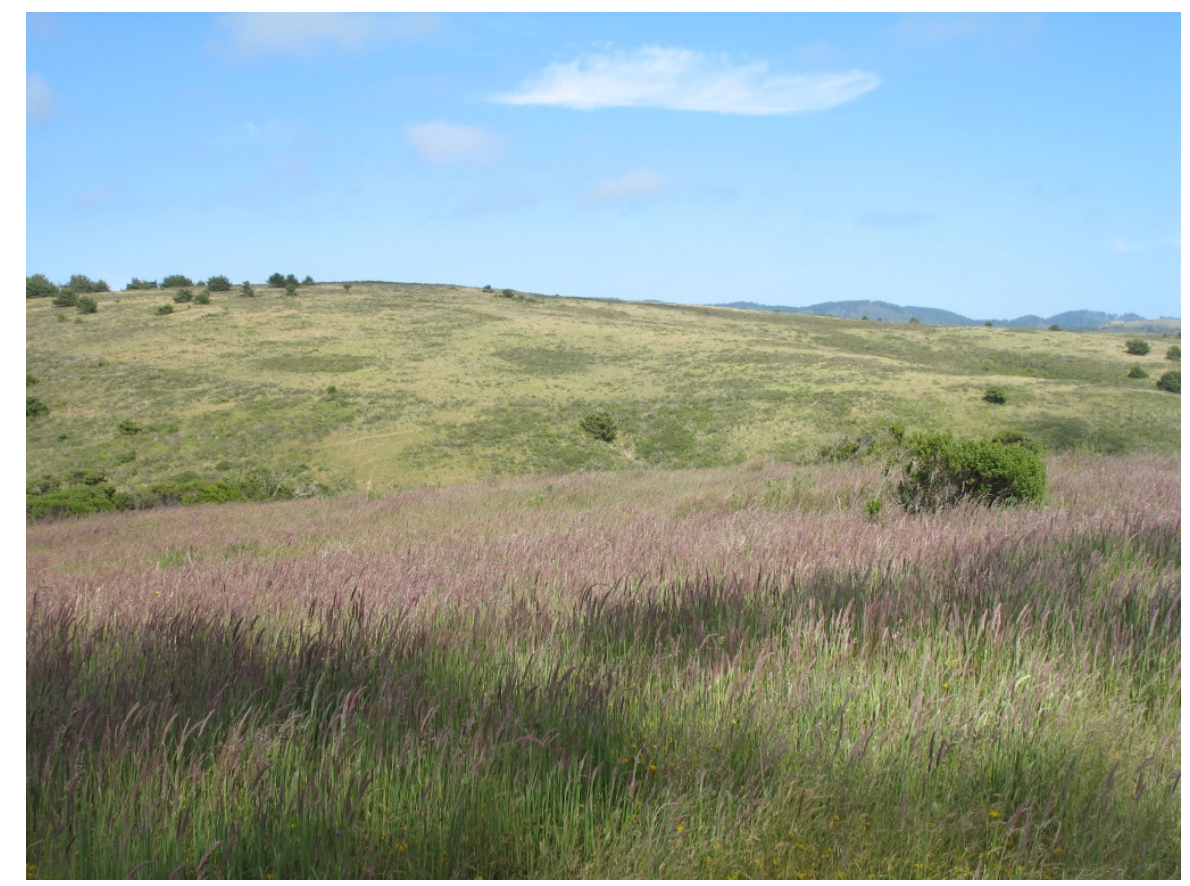

Grazing lands at Point Reyes National Seashore, CA, June 2011 (photo by Amber Kerr). 


\section{TABLe Of Contents}

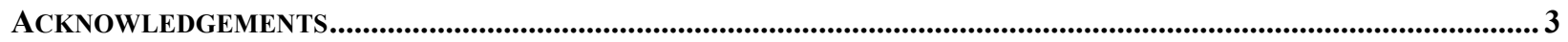

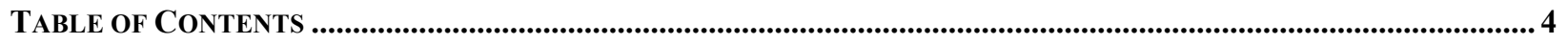

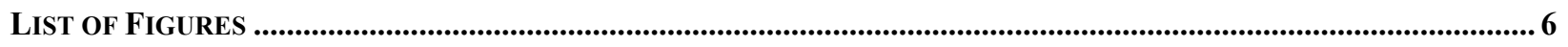

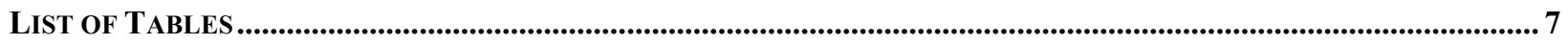

EXECUTIVE SUMMARY ...................................................................................................................................................... 8

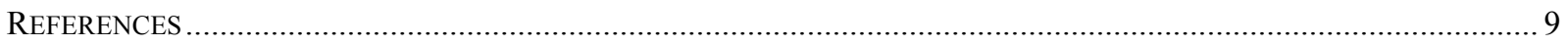

CHAPTER ONE: SCOPE, DEFINITIONS, AND STATISTICS ...........................................................................................10

AleXANDros Xides AND AMBER KerR

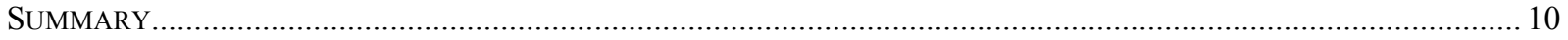

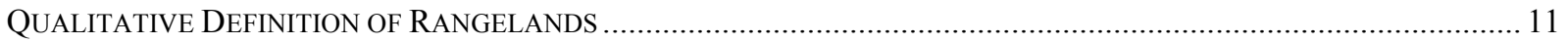

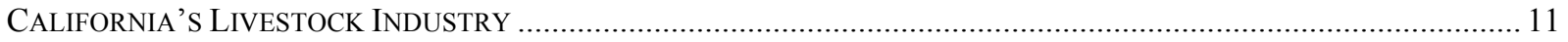

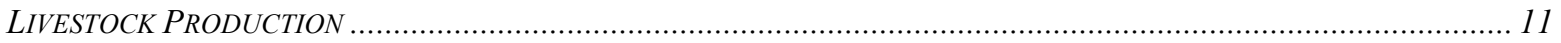

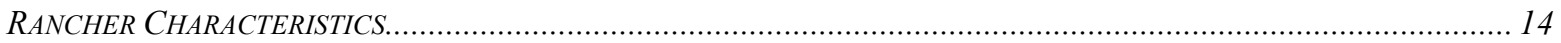

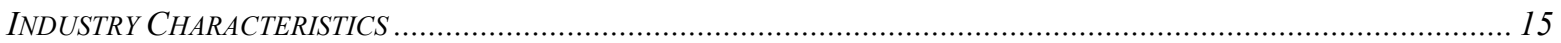

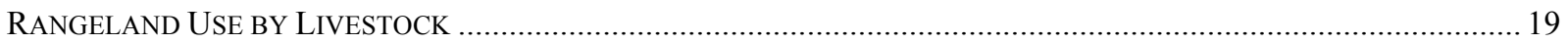

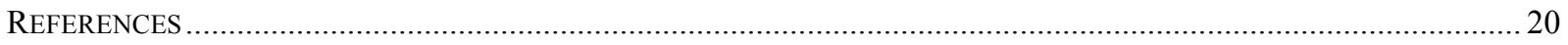

Chapter TWo: Projected FUtURe WATER STRESS IN RANGELANDS ................................................................... 22

Julian Reyes, Alexandros Xides, Hyeyeong Choe, Jennifer Balachowski, Amber KerR, AND CASey

PETERS

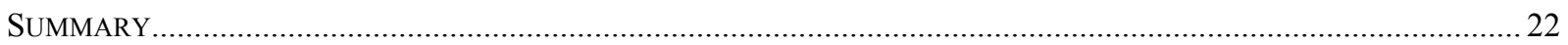

Predicting FutURe Climate ChANGE IN CALIFORnia .................................................................................. 22

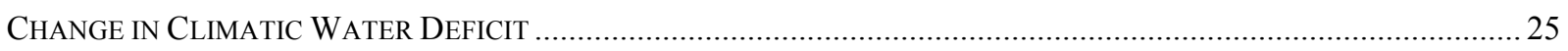

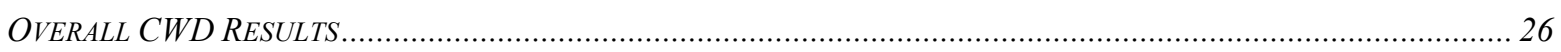

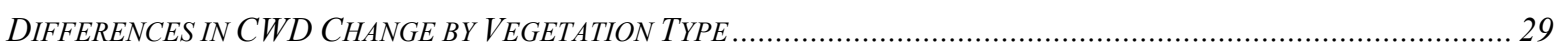

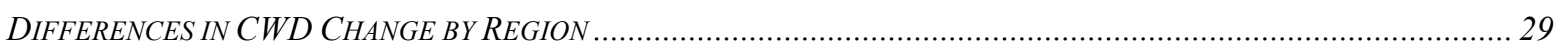

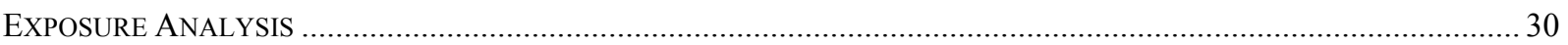

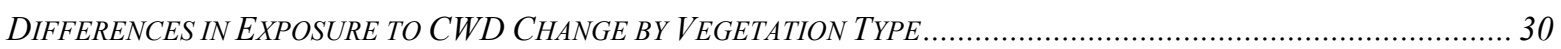

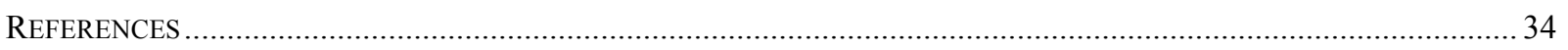

CHAPTER THREE: ANTICIPATED CLIMATIC AND BIOPHYSICAL CHANGES .........................................................35

JenNifer Balachowski, Pelayo Alvarez, AND Julian Reyes

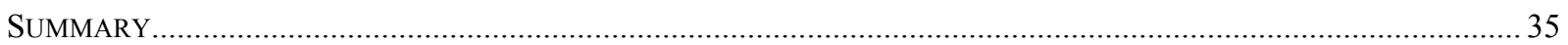

THE INTERGOVERNMENTAL PANEL ON CLIMATE CHANGE (IPCC) .................................................................. 35

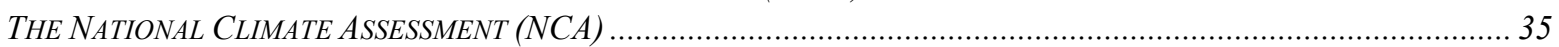

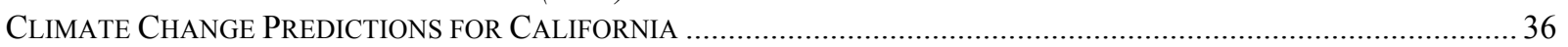

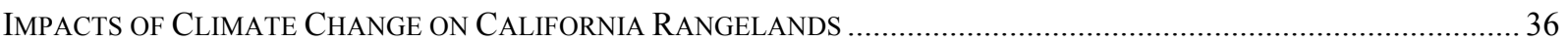

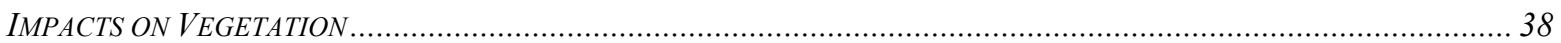

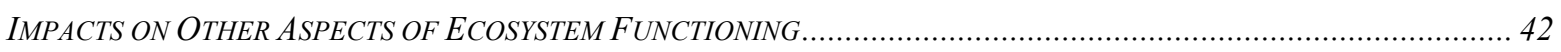

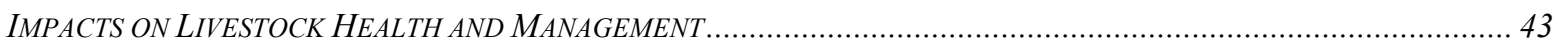

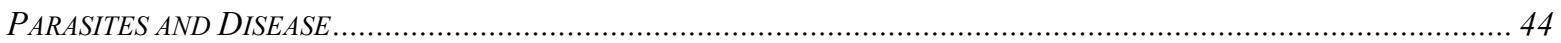

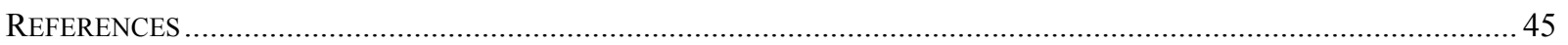

CHAPTER FOUR: NON-CLIMATIC FACTORS AFFECTING RANGELAND SUSTAINABILITY ............................................50

Pelayo Alvarez AND Amber KerR

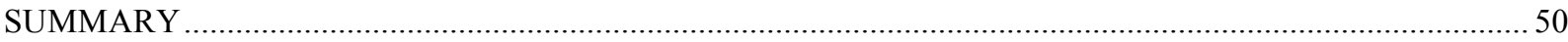

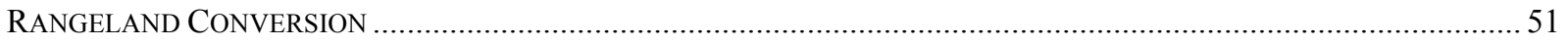




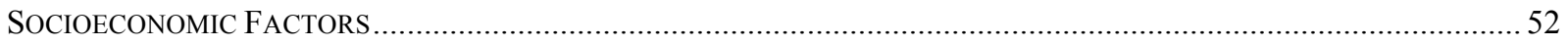

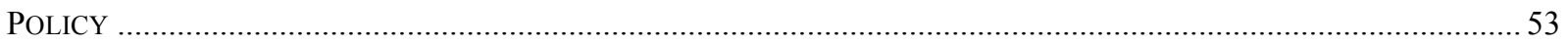

EXAMPLES OF KEY INTERACTIONS BETWEEN CLIMATE AND NON-CLIMATE FACTORS ......................................... 55

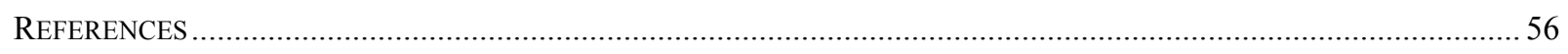

Chapter Five: Adaptation OPtions for Rangeland Managers ..............................................................58

JULIAN REYES, JOEL BROWN, AND LESLIE ROCHE

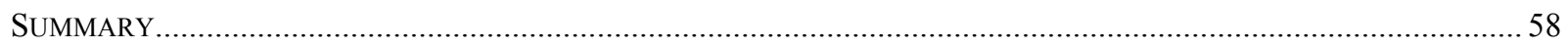

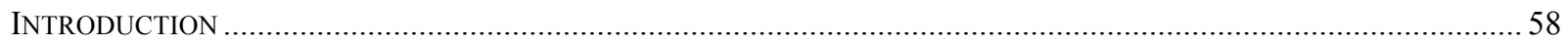

GRAZING MANAGEMENT AS THE KEY TO RANGELAND MANAGEMENT AND AdAPTATION ...................................58

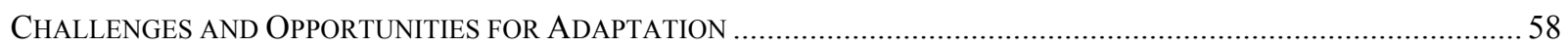

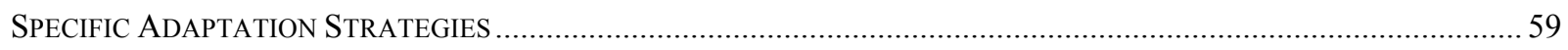

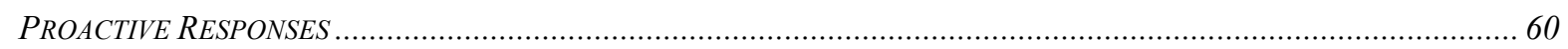

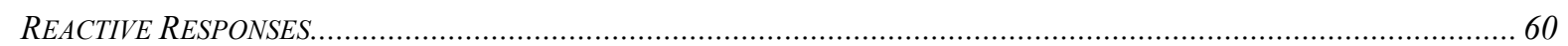

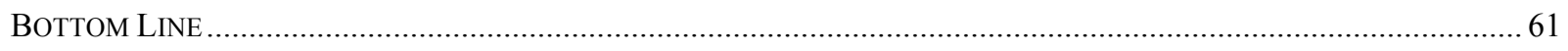

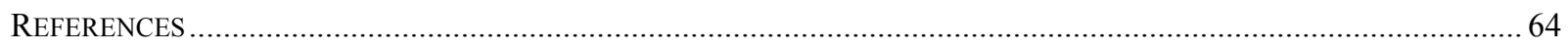

Chapter Six: Conclusions and Future Research NeEdS....................................................................... 65

Pelayo Alvarez AND Amber KerR

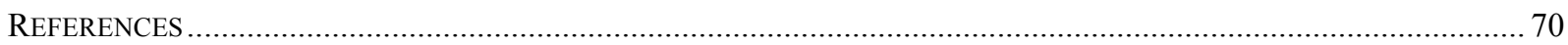




\section{List OF Figures}

Figure 1.1: Inventories of beef cows, sheep, and goats in California .................................................. 14

Figure 1.2: Beef cattle cash receipts, or revenues (USDA ERS 2015) and Average Annual Beef Prices ..... 15

Figure 1.3: Age characteristics of California ranchers..................................................................... 16

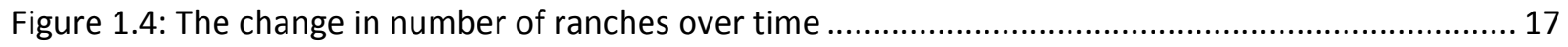

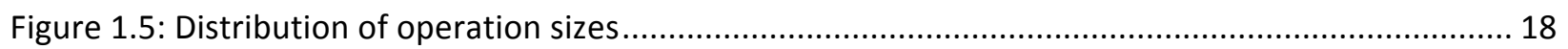

Figure 1.6: Head of livestock within each ranch size category .......................................................... 19

Figure 1.7: Estimated total monthly livestock forage demand in 2012 ............................................. 20

Figure 1.8: Change in forage productivity between a wet and dry year............................................... 21

Figure 2.1: Flow chart for modeling the future change in hydrological variables including climatic water

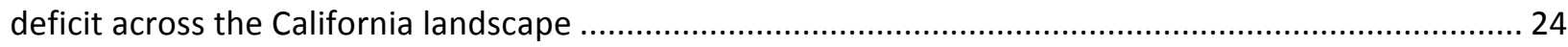

Figure 2.2: Map of current rangeland vegetation types in California............................................... 26

Figure 2.3: Mean baseline climatic water deficit (CWD) for 1981-2010 for rangeland vegetation types. 28 Figure 2.4: Projected total change in annual climatic water deficit (CWD), an indicator of plant water

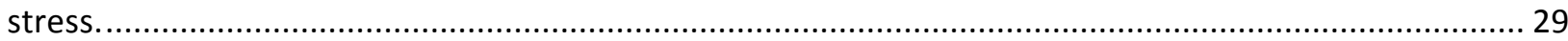

Figure 2.5: Exposure analysis maps for two climate model projections of future climate from 2040-2069.

Figure 4.1: Conceptual map of climatic and non-climatic factors affecting rangeland productivity........ 51

Figure 4.2: Conversion from rangeland to other land uses, 1984-2008 .............................................. 53 


\section{LIST OF TABLES}

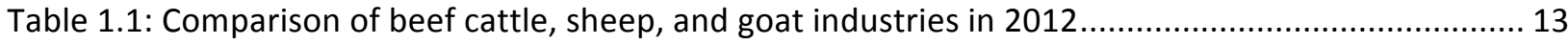

Table 2.1: Vegetation types with the highest and lowest proportions of land cover in the top $25 \%$ of

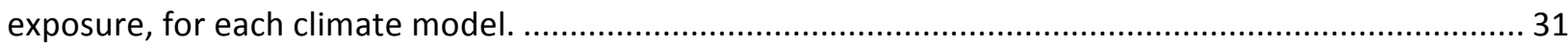

Table 2.2: Area of critical exposure by climate model and rangeland vegetation type........................... 32

Table 2.3: The top twenty counties ranked by beef cattle inventory in 2007 ........................................ 34

Table 3.1: Climate and climate-related changes identified by the NCA for the Southwest Region........... 37

Table 3.2: A brief introduction to changes expected in California's climate and other large-scale, climate-

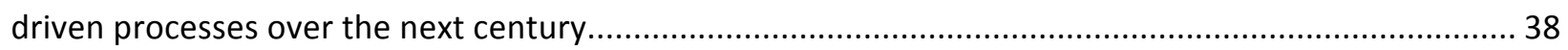

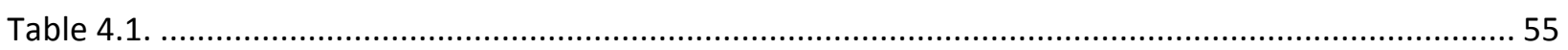

Table 5.1: Strategies for drought impact management based on the 2011 California Rangeland Decision-

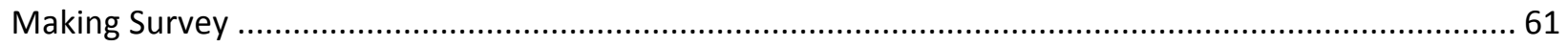

Table 5.2: Proactive and reactive on-property responses to changes in climate, such as drought........... 63 


\section{EXECUTIVE SUMMARY}

California's Mediterranean-climate rangelands are biogeographically distinct from the arid rangelands of the Great Basin and are a major contributor to the state's agricultural economy. The USDA California Climate Hub developed this statewide rangeland climate vulnerability assessment to complement an earlier Southwest regional assessment written in collaboration with the Southwest Climate Hub (Elias et al. 2015). The purpose of this assessment is to highlight vulnerabilities specific to California rangelands' unique geography and ecology, to further engage stakeholders in the livestock industry, and to provide a foundation for developing tools and practices that increase rancher and rangeland resilience to climate change.

Rangelands provide millions of acres of forage, supporting California's multi-billion dollar animal agriculture sector in addition to providing myriad ecosystem services. Declines in forage quantity and overall rangeland health critically impact the livestock industry and the ability of California's ranchers to maintain viable enterprises. In recent years, revenues and net incomes have declined across the industry, a trend exacerbated by recent historically severe drought. In Chapter 1, we provide an overview of the present state of California's livestock industry in the context of historical trends, as well as a working definition of "rangelands" to be used throughout the report.

Forage productivity and rangeland sustainability depend strongly on water availability. In Chapter 2, we present an original spatial analysis - termed a climate "exposure analysis"describing how water availability and other climatic factors may change for rangelands in the coming decades. Our analysis indicates that while declines in forage productivity are expected across the state, certain areas and vegetation types may be particularly exposed to climatic changes. For example, grasslands and woodlands in the Sierra foothills are more exposed than in the Coast Range foothills. It is important to consider the different uses of each vegetation type: for example, while hardwood woodland is less exposed than desert woodland, it supports more livestock and thus its exposure may be more consequential to the ranching industry. At the county level, many of the top beef cattle producing counties have relatively low exposure; those with high cattle production and high exposure include Humboldt, Siskiyou, Shasta, and Madera.

Rangeland sustainability is influenced by both climatic and non-climatic factors. Chapter 3 summarizes the climatic changes expected for California and their potential effects on rangeland vegetation and livestock. California is expected to experience increasing temperatures; increasing precipitation variability; more frequent and intense droughts and extreme rainfall events; and increasing wildfire risk. Predicting the overall effect of climate change on rangeland sustainability is complicated by uncertainty in precipitation forecasts. In general, though, we anticipate reduced forage quality (digestibility and palatability); changes in plant community composition, including increased weed abundances; and increasing livestock health concerns, including heat stress, reduced access to water, and greater prevalence of parasites and disease. 
In Chapter 4, we discuss non-climate factors affecting rangeland sustainability. Key challenges include low profitability, land use conversion, either to crops or urban development, and a lack of economic and social incentives for young ranchers to enter or stay in the industry. On the other hand, rangelands stand to benefit from growing recognition of the environmental and cultural benefits they provide, as well as from better communication among rancher interest groups, conservation organizations, and government agencies. These non-climate factors can interact with climatic and biophysical changes, sometimes in unexpected ways. For example, though a changing climate may exacerbate pressures to hasten rangeland conversion to agricultural or urban use, this pressure may be countered by policies that formalize the value of rangelands in providing climate adaptation services such as watershed protection and wildlife corridors.

Although ranchers face a variety of risks and challenges related to climate change, adaptation actions-particularly those involving changes in livestock grazing management — can help reduce their vulnerability and improve rangeland sustainability. In Chapter 5, we discuss both the proactive efforts that ranchers may take to reduce vulnerability and the reactive efforts triggered by weather or climatic changes that farmers experience. Proactive adaptation is typically practiced on-site and can include reducing stocking rates, modifying livestock composition, and making improvements to on-ranch infrastructure. Reactive adaptation can include on-site actions such as reducing herd sizes and purchasing additional feed. It can also include off-site actions such as moving herds to a new location and taking steps to earn additional off-ranch income.

Finally, while the primary stakeholders in this report are the ranchers and rural residents who depend on California's livestock industry, we also provide guidance for the academic research community by identifying key information gaps. These areas are highlighted throughout the chapters as they arise and are also summarized in Chapter 6. For example, empirical studies incorporating realistic changes in multiple climate and non-climate variables (e.g., temperature, precipitation, soil nutrient concentrations) would help refine predictions of rangeland vegetation change (Chapter 3). In addition, climate forecasts at spatial and temporal scales relevant to rancher decision-making are needed (Chapter 3). And finally, decision support tools are needed to help ranchers make and implement the decisions that are key to meeting their management and adaptation objectives. These tools can be built using the best available science and updated as more data and information become available (Chapter 5).

\section{REFERENCES}

Elias, E., C. Steele, K. Havstad, K. Steenwerth, J. Chambers, H. Deswood, A. Kerr, A. Rango, M. Schwartz, P. Stine, and R. Steele. 2015. Southwest Regional Climate Hub and 
California Subsidiary Hub Assessment of Climate Change Vulnerability and Adaptation and Mitigation Strategies. United States Department of Agriculture, Washington, D.C. 


\section{Chapter One: Scope, Definitions, And Statistics}

Alexandros Xides and Amber Kerr

\section{SUMMARY}

Rangelands provide millions of acres of forage to support California's multi-billion dollar animal agriculture sectormost significantly, its beef cattle, sheep, and goat industries - as well as providing wildlife habitat and numerous other critical ecosystem services. Decreases in forage availability and rangeland health can have profound impacts on livestock

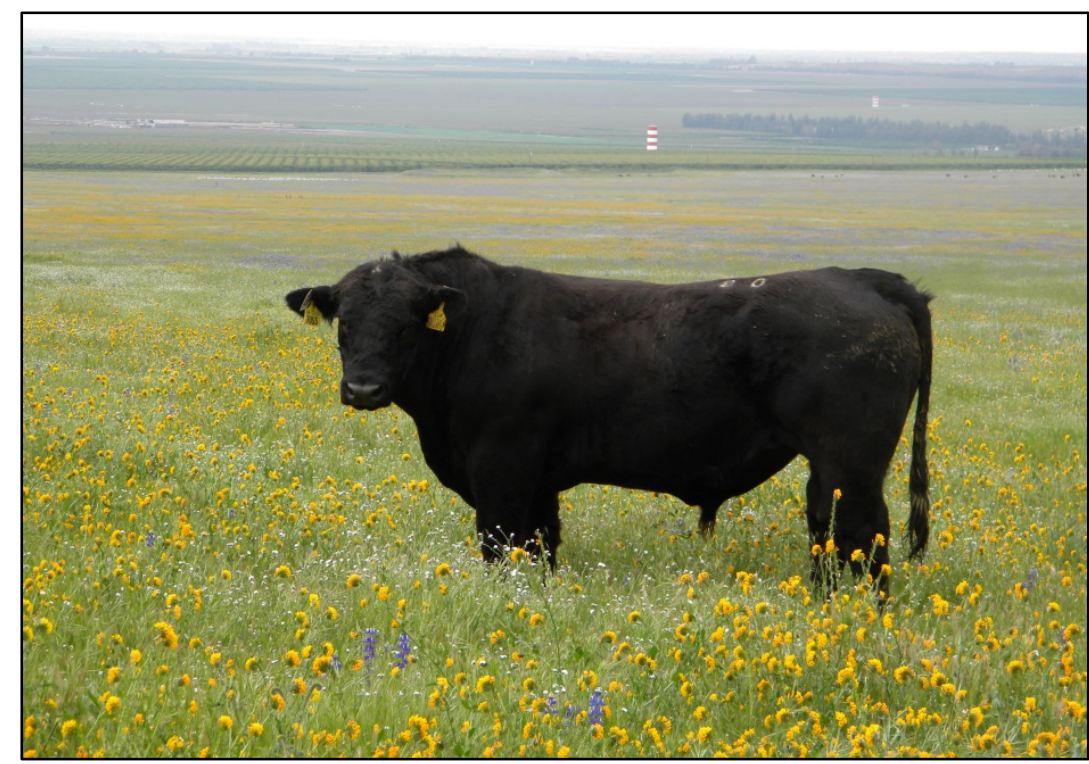

Tejon Ranch, CA, 2010 (photo by Rebecca Wenk). production. Therefore, the stakeholders in this rangeland vulnerability assessment are the many thousands of ranchers and millions of consumers who depend on a thriving livestock sector in California. The economic and environmental importance of this industry, as well as the social and personal importance of the ranching lifestyle to California's ranchers, motivates this study regarding the future of rangelands.

California's beef cattle, sheep, and goat industries have been challenged due to a combination of environmental and economic factors. Inventories of cattle and sheep have steadily fallen over the past several decades, though the relatively small goat inventory in the state has increased. In recent years, revenues and net income have both fallen across these three industries. The decline in these numbers has only been exacerbated by recent drought conditions. As a result, some ranchers are beginning to move their operations out of state or are leaving the industry altogether. 


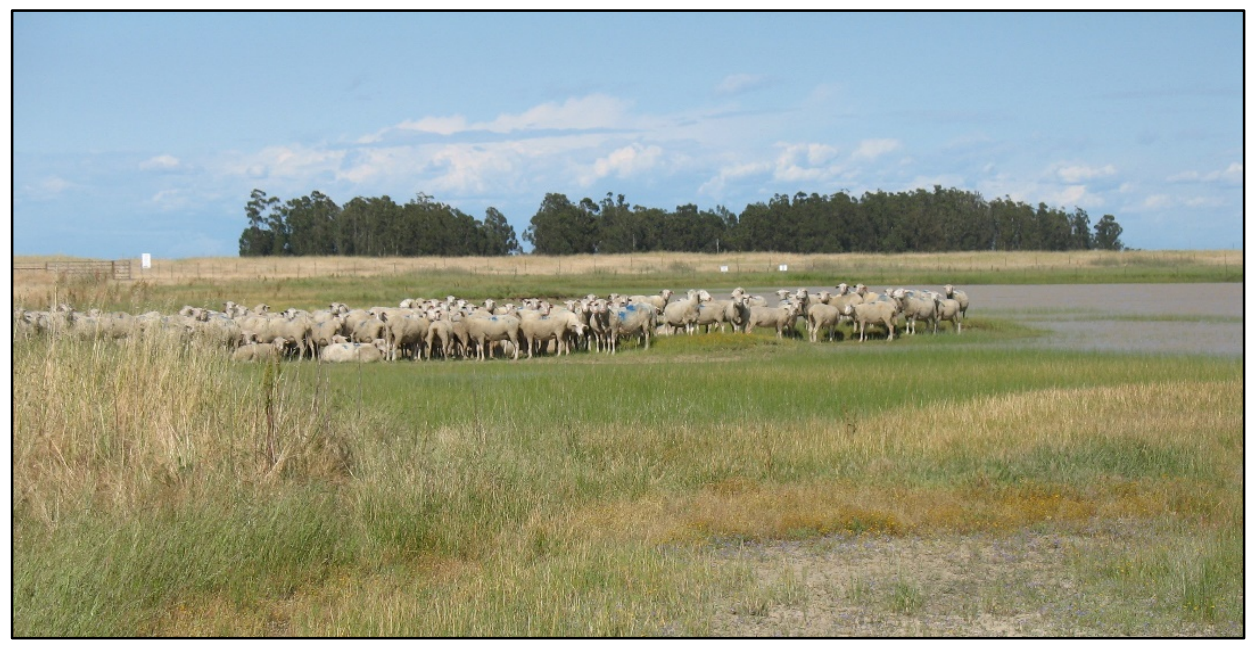

Sheep grazing at Jepson Prairie Reserve, Dixon, CA, May 2011. (Photo by Amber Kerr.)

\title{
Qualitative Definition of Rangelands
}

Rangeland is defined in a number of ways using many factors, including ecosystem type, dominant vegetation, and utility for livestock grazing. We draw our conceptual definition from the Forest and Rangeland Resources Assessment and Policy Act of 1977 (PRC § 4789-4789.7), which describes rangelands as

\begin{abstract}
land on which the existing vegetation, whether growing naturally or through management, is suitable for grazing or browsing of domestic livestock for at least a portion of the year. Rangeland includes any natural grasslands, savannas, shrublands (including chaparral), deserts, wetlands, and woodlands (including Eastside ponderosa pine, pinyon, juniper, and oak) which support a vegetative cover of native grasses, grasslike plants, forbs, shrubs, or naturalized species.
\end{abstract}

For the purposes of our analyses, this definition does not include irrigated pasture. We have also defined rangeland in more concrete terms for the exposure analysis presented in Chapter 2 by defining Wildlife-Habitat Relationship (WHR) vegetation community types that are used as rangeland in California. The WHR schema is used by the California Department of Forestry and Fire Protection (CAL FIRE) in their Fire and Resource Assessment Program (FRAP) reports. The vegetation community types considered rangeland in this report are conifer woodland, desert shrub, desert woodland, hardwood woodland, herbaceous, shrub, and wetland.

\section{CALIFORNIA's LiVESTOCK INDUSTRY}

\section{LIVESTOCK PRODUCTION}

The beef cattle industry is of particular importance to California and its residents for both social and economic reasons. It employs almost four times as many operators and produces nearly 30 times the revenue of the sheep and goat industries combined (Table 1.1). 
Dairy cattle are not included in our analyses because they are primarily raised in confinement or feedlots and with transported forage and grain, rather than on rangelands. Some dairy cattle operations along California's northern coast are range-based, but they are a small enough contribution that useful data on the practice is scarce (Spiegal et al. 2016).

The state's sheep and beef cattle inventories have both declined over the past few decades, though the goat inventory has grown (Fig. 1.1). From 2002 to 2012,

\begin{tabular}{|l|c|c|c|}
\hline \multicolumn{4}{|c|}{ Table 1.1: Comparison of beef cattle, sheep, and goat industries in 2012. } \\
\hline & Beef Cattle & Sheep & Goats \\
\hline Inventory & $1,324,558$ & 668,517 & 140,042 \\
\hline Operators & 19,203 & \multicolumn{2}{|c|}{5,453} \\
\hline Revenues & $\$ 3.03 \mathrm{~B}$ & $\$ 102.9 \mathrm{M}$ \\
\hline Net cash income & $-\$ 8.9 \mathrm{M}$ & $-\$ 14.9 \mathrm{M}$ \\
\hline \multicolumn{2}{|c|}{ Sources: (USDA NASS 2012 a, USDA NASS $2012 b$, USDA ERS 2015). } \\
\hline
\end{tabular}

California saw a $20 \%$ net decrease in statewide beef cattle inventory (USDA NASS 2012a).

Furthermore, after 2012, California's beef cattle inventory has fallen at eight times the rate of the national inventory (USDA NASS Cattle Inventory Surveys 2013-15).

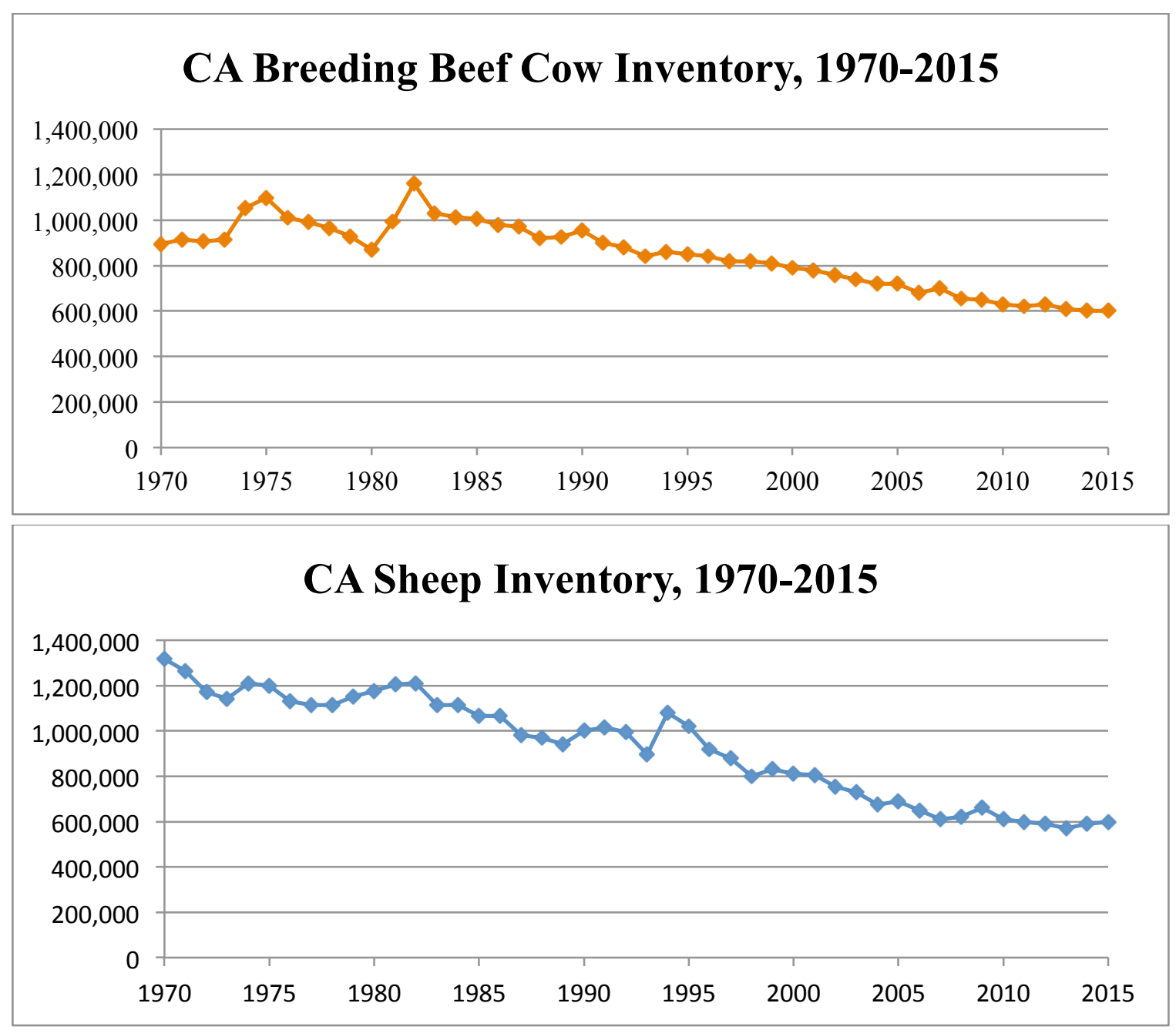




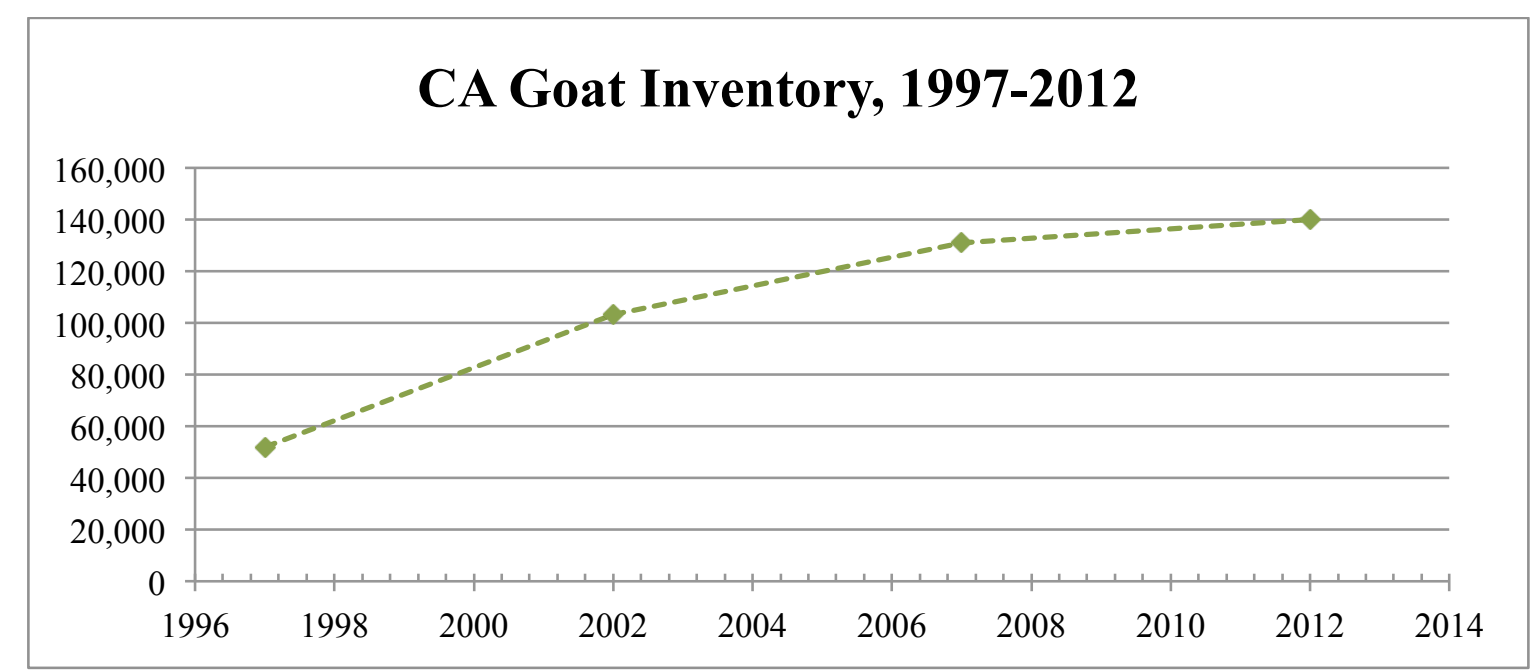

Figure 1.1: Inventories of beef cows, sheep, and goats in California (USDA NASS 1970-2015b, a, 1997, 2002, 2007, 2012a). Annual data available for beef cows that have calved, but not for all beef cattle. Only Census data available for goats.

As a result, revenues from California's beef cattle fell by 6\% after 2012 while US revenues and average retail prices for beef continued to rise (Fig. 1.2). In the same period, sheep and goat revenues also fell by $11 \%$ and $6 \%$, respectively (USDA NASS 2012b, 2013). The recent decline in beef cattle revenue follows a period from 2009-2012 in which the revenue nearly doubled; such variability is typical of the beef industry.

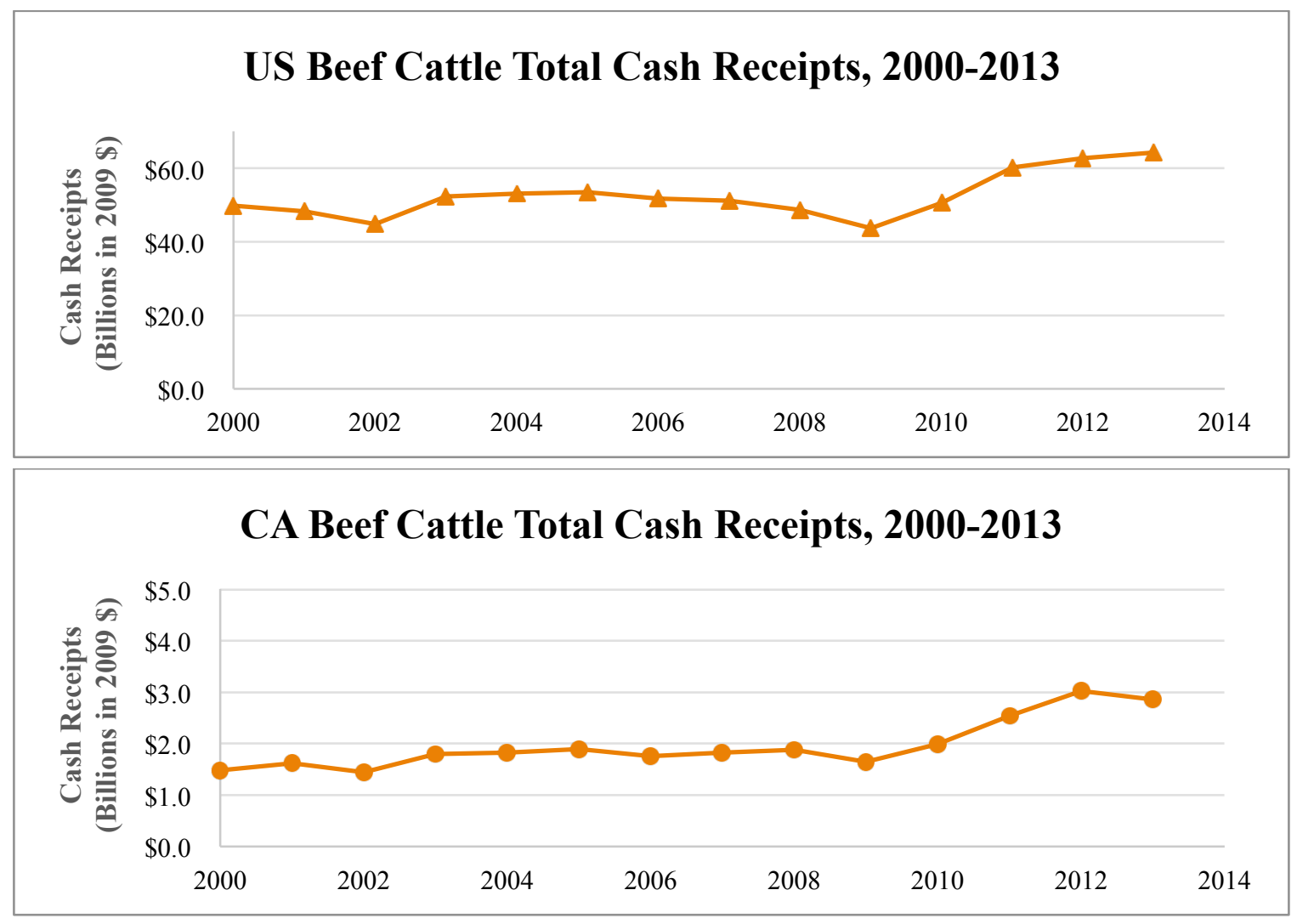




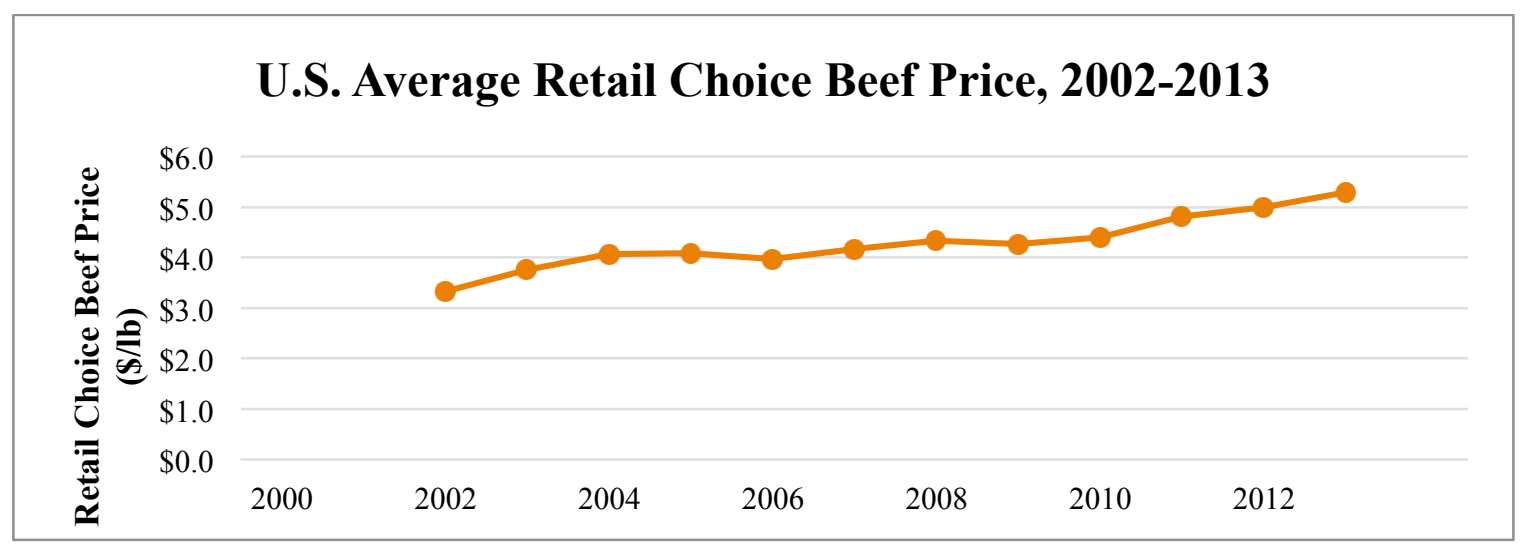

Figure 1.2: Beef cattle cash receipts, or revenues (USDA ERS 2015) and Average Annual Beef Prices.

California's beef cattle, sheep, and goat industries all experienced a net loss of income in 2012, the most recent year for which complete economic data are available. Beef cattle operations lost $\$ 9$ million while sheep and goat operations lost a combined \$15 million. These net losses of cash income over the year contrast with the state's dairy industry and fruit/tree nut agriculture, which have posted net gains in the billions over the past decade (USDA NASS 2012a).

In a survey conducted by UC Davis researchers, two-thirds of surveyed beef cattle ranchers indicate that ranching is a critical source of income, but the same proportion also noted that their personal connection to the ranching lifestyle and heritage was more important to them than pure economic returns (Roche et al. 2015).

\section{RANCHER CHARACTERISTICS}

Principal ranch operators for the various livestock in California share some demographic similarities. The average beef cattle, sheep, or goat rancher in California has spent more than 20 years in their respective industry, affirming the personal importance of the ranching lifestyle. The average rancher also is approximately 60 years old, with a quarter of beef cattle ranchers and a fifth of sheep and goat ranchers being 70 years or older. The average age of sheep and goat ranchers is trending upwards and rose above 60 years in 2012, while the age of beef cattle ranchers remains stable just below 60 years (Fig. 1.3). According to NASS, the stability of the average age of cattle ranchers may be due to older ranchers with larger operations exiting the beef cattle industry (Fig. 1.4). 


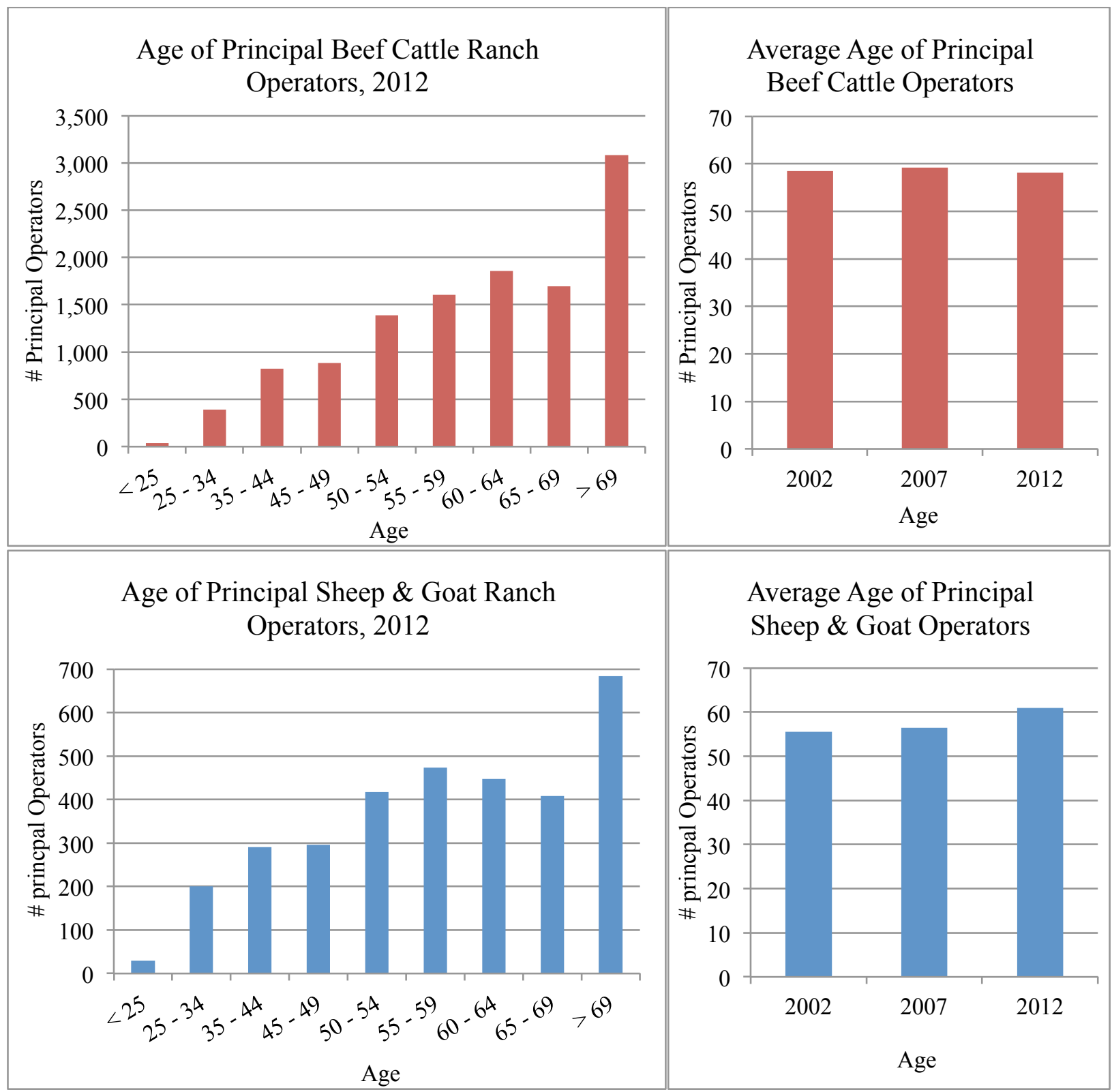

Figure 1.3: Age characteristics of California ranchers (USDA NASS 2012a).

\section{INDUSTRY CHARACTERISTICS}

The majority of beef cattle ranchers in California are cow-calf producers, meaning that they have a stable herd of brood cows that produce calves to be sold after weaning or retained for fattening, provided that adequate forage or feed is available. If sold, these calves will often be obtained by stocker operations, which are designed to produce profit by grazing the weaned calves for about six months. It is important to note that the vast majority of stocker operators also own cow-calf operations. Later, these cattle are typically put in feedlots for fattening prior to slaughter and packing. For this reason, we have chosen to focus on cow-calf operations, which constitute a large majority of rangeland cattle grazing in California. 
The state's sheep and goat industries are considerably smaller economically than the beef cattle or dairy industries, though they produce a larger variety of products such as wool, mohair, lamb meat, mutton, and milk. Lambing takes place in late fall and winter, and in spring, the young lambs are sold to feeder operations where they are fattened for slaughter (Spiegal et al. 2016). Wool and milk operations will usually retain sheep and goats for annual shearing in the spring. Sheep and goats are not nearly as dependent on rangelands as are beef cattle; in fact, around three-fourths of sheep herds are not consistently grazed on what this report defines as rangeland. This majority of sheep are raised to varying extents on agricultural residue (such as alfalfa stubble), grazing levees, and duck clubs. There are few useful statistics kept on this practice (Lesa Eidman, personal communication, 27 August 2015).

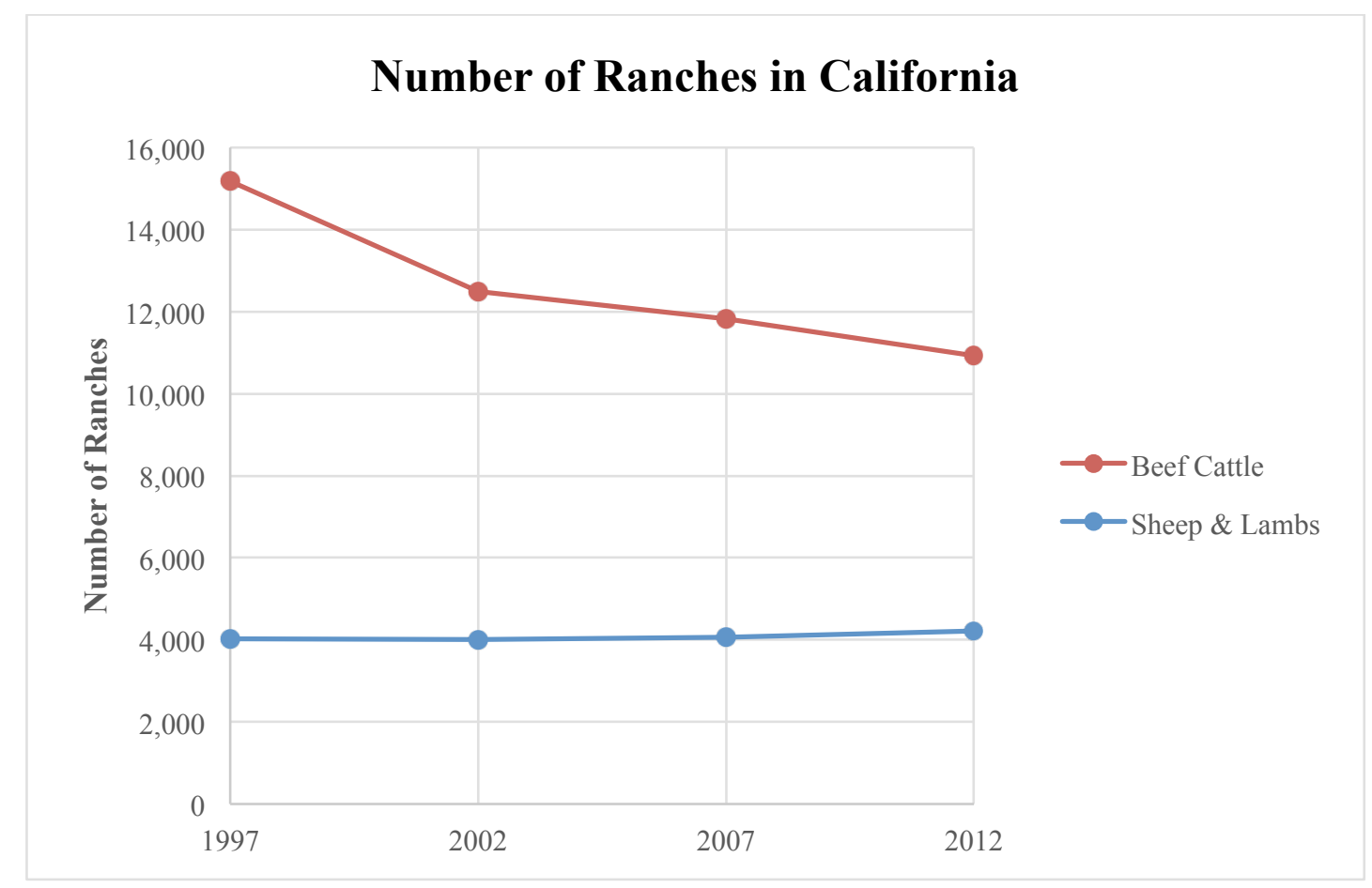

Figure 1.4: The change in number of ranches over time (USDA NASS 1997, 2002, 2007, 2012a)

California's beef cattle and sheep industries are structured differently in terms of number of operations and size of livestock inventory. These industries have changed in dissimilar ways over time. In terms of their share of California's inventory, mid-sized ranching operations have dominated the beef cattle industry consistently from 2002-2012. This dominance has persisted despite the fact that the number of small beef cattle ranches ( $\leq 9$ cows) has risen while larger ranches declined (Fig. 1.5), leading to a net decrease in the number of beef cattle operations in the state (Fig. 1.4). 


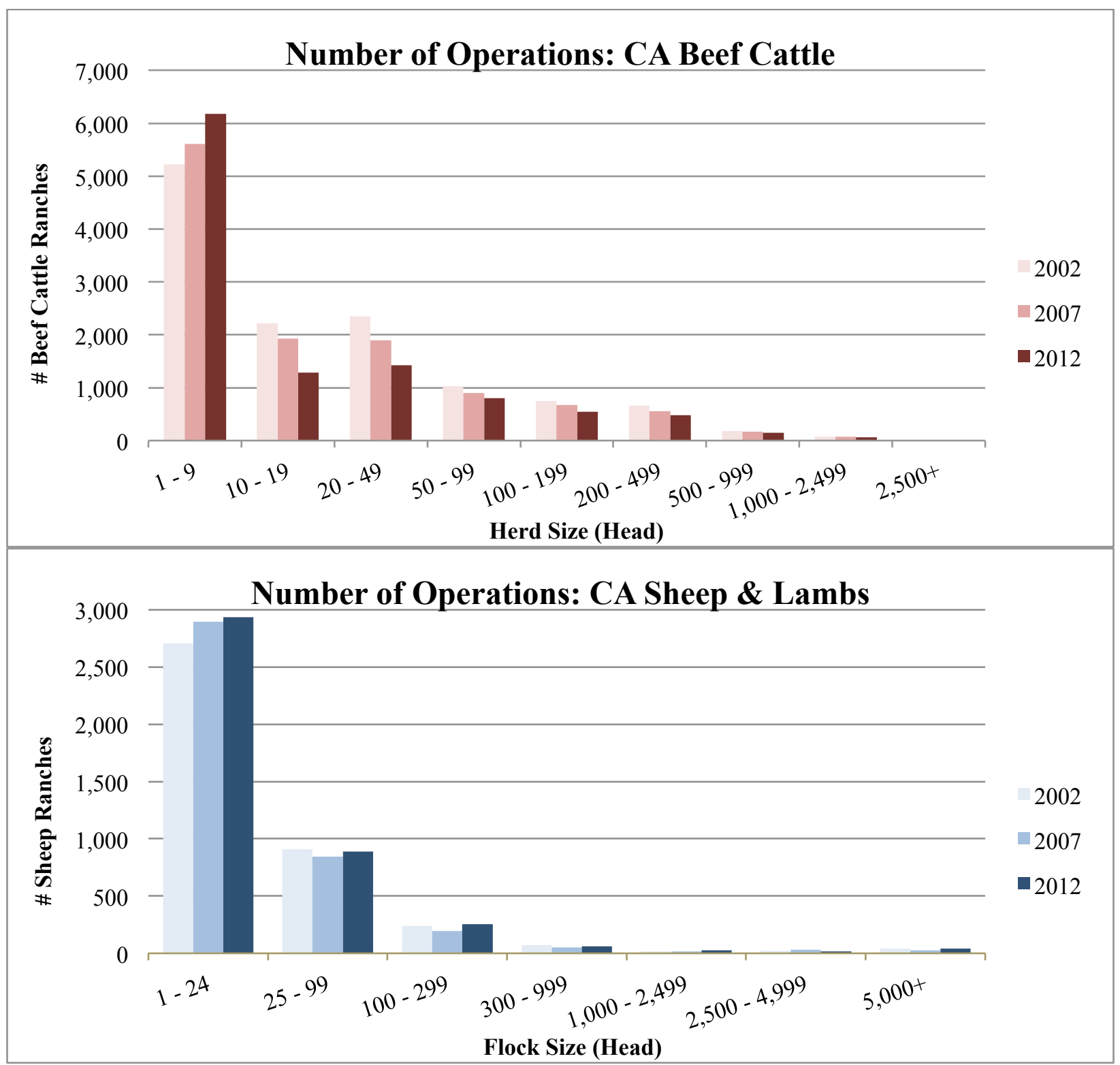

Figure 1.5: Distribution of operation sizes (USDA NASS 2012a).

By contrast, the state's sheep inventory during those 10 years has been continuously dominated by a small number of very large operations handling 5,000 or more sheep each. The share of the sheep inventory held by the largest operations sharply declined in 2007, but these operations had recovered significantly by 2012 (Fig. 1.6). During that time, the total number of sheep ranches actually increased slightly due to net growth in the number of small operations (Fig. 1.4 and 1.5). As a result, from 2002-2012, California's sheep inventory fell by only $9 \%$ (compared to the $20 \%$ decrease in head of beef cattle) from 2002-2012 (USDA NASS 2002, 2012a).

When comparing sheep and beef cattle inventories, it is important to note that one sheep is approximately equivalent to one-fifth of a cow in terms of forage requirement and meat 
production. Therefore, beef cattle production demands significantly more forage (Fig. 1.7) than both the sheep and goat industries, despite consisting of fewer total animals.

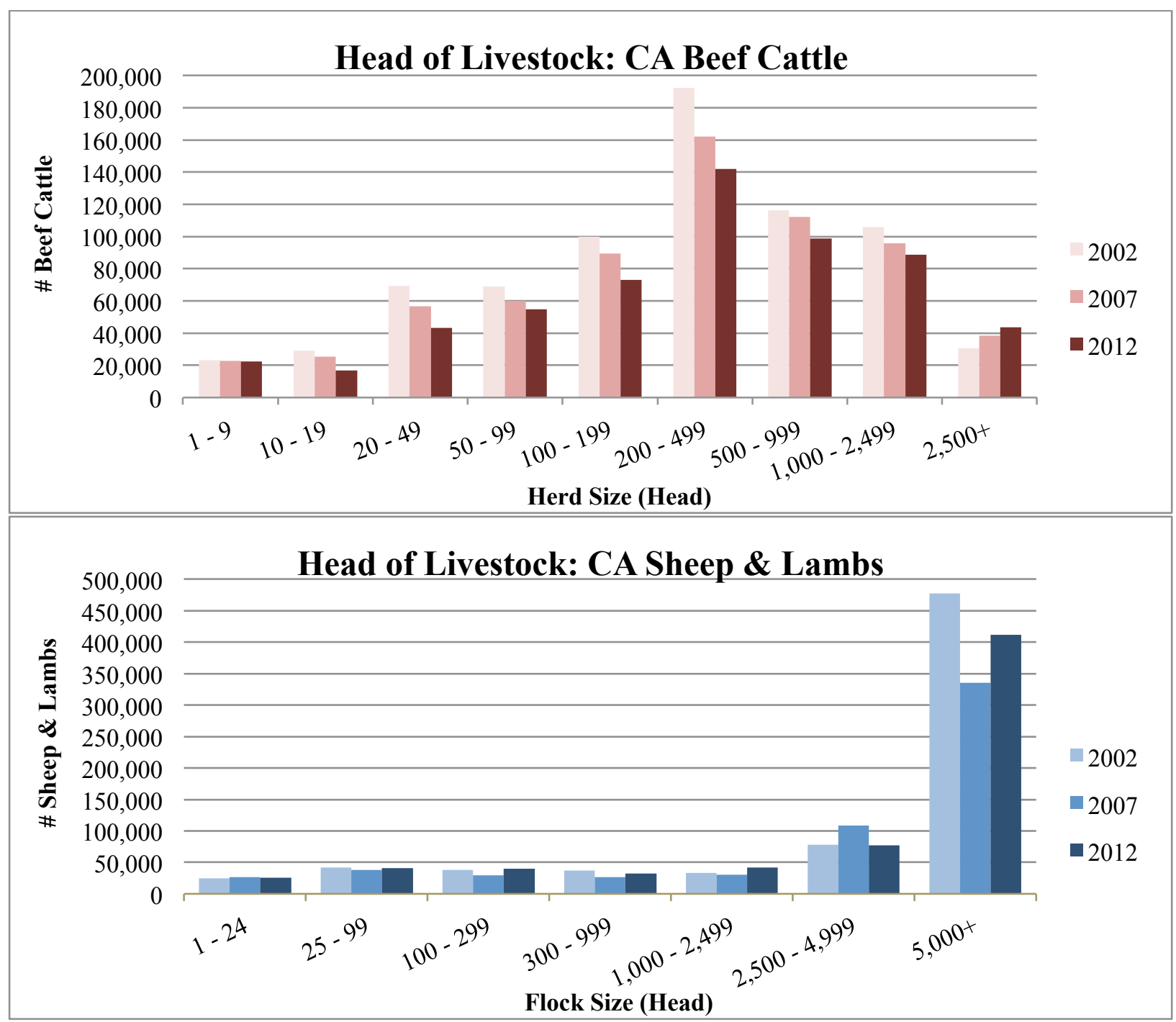

Figure 1.6: Head of livestock within each ranch size category (USDA NASS 2012a). 


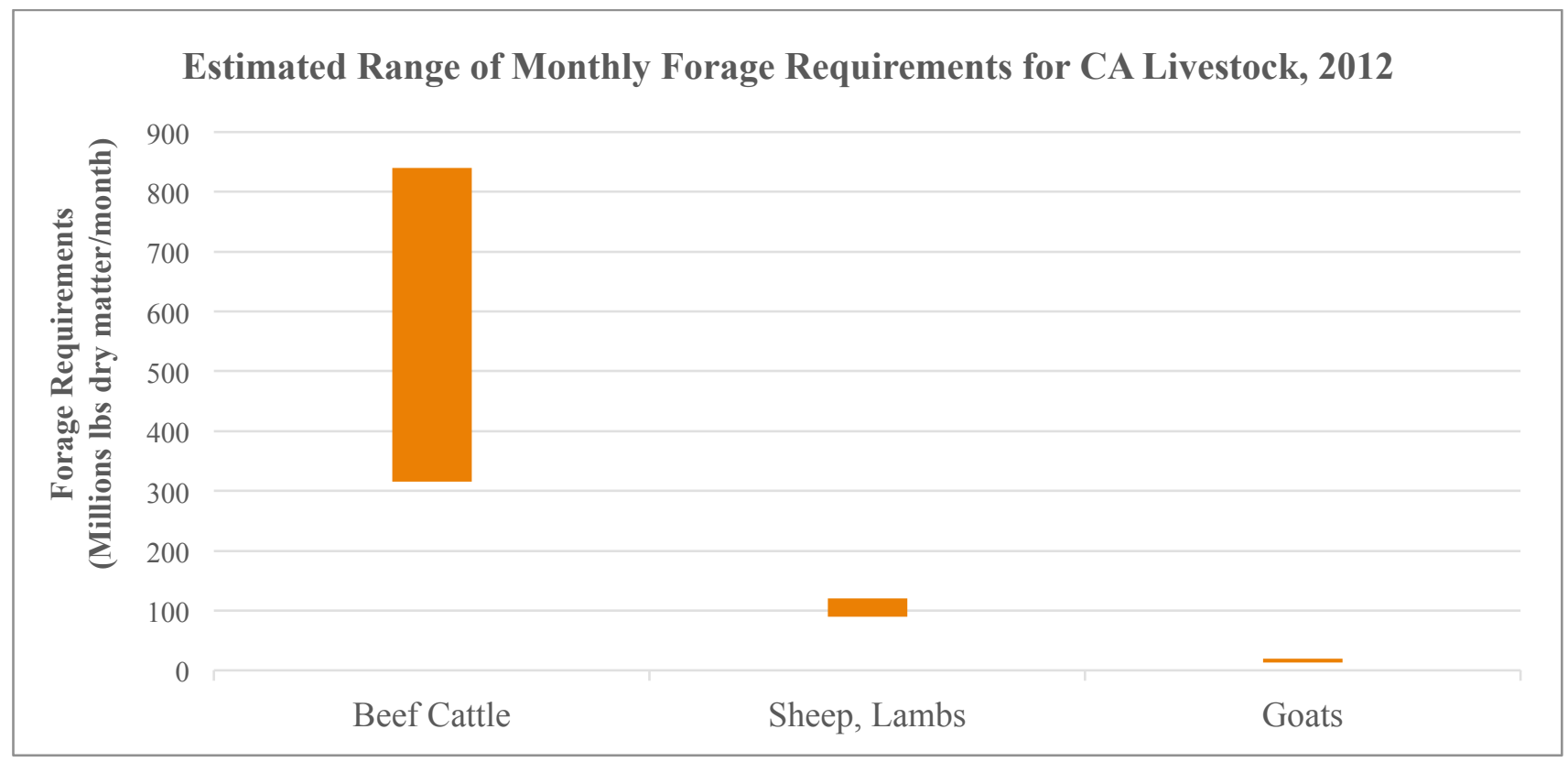

Figure 1.7: Estimated total monthly livestock forage demand in 2012, based on Census inventory numbers and range of possible Animal Unit Equivalents (USDA NRCS 2003). One AUE is defined as one mature 1,000-pound beef cow. The lower bound marks the forage demand if the entire inventory were grazed together at the point of lowest AUE, and the higher bound marks demand if all head were grazed together at the point of highest AUE.

\section{RANGELAND USE BY LIVESTOCK}

California's livestock graze a vast amount of rangeland, amounting to approximately 14 million hectares in 2010, or one-third of the state's land area (Roche et al. 2015). The amount of forage provided by this land can vary drastically from year to year, and because interannual variability, climate change, and drought impacts are heterogeneous throughout California, so too are the changes in rangeland forage productivity. The extent to which climate change affects precipitation patterns, temperatures, and drought frequency will have significant impacts on forage productivity. For instance, eastern San Luis Obispo County averaged 4,000 lbs of forage per acre of rangeland in spring 2006, but the dry 2013/2014 winter slashed that number to 31 lbs/acre in the spring of 2014 (Fig. 1.8). Three-fourths of San Luis Obispo's cattle were sold or moved out of the county as a result of the decrease in forage availability and the associated decrease in grazing authorized on public lands (Battany et al. 2014).

The Bureau of Land Management (BLM) and other agencies managing lands used for grazing (such as the US Forest Service) also adjust the number of Animal Unit Months (AUMs) of grazing authorized on federal lands, based on a variety of factors that include drought and forage productivity. For example, BLM could have authorized up to 12.4 million AUMs of grazing in 2012, but limited grazing to only 9 million AUMs due to forage depletion and resource protection needs. These federal lands serve as a significant resource base for ranchers, especially since federal grazing fees tend to be lower than those on state-owned or private lands. The reduction in grazing on federal lands has constituted a diminishing resource base for California ranchers (US Department of the Interior 2013). 


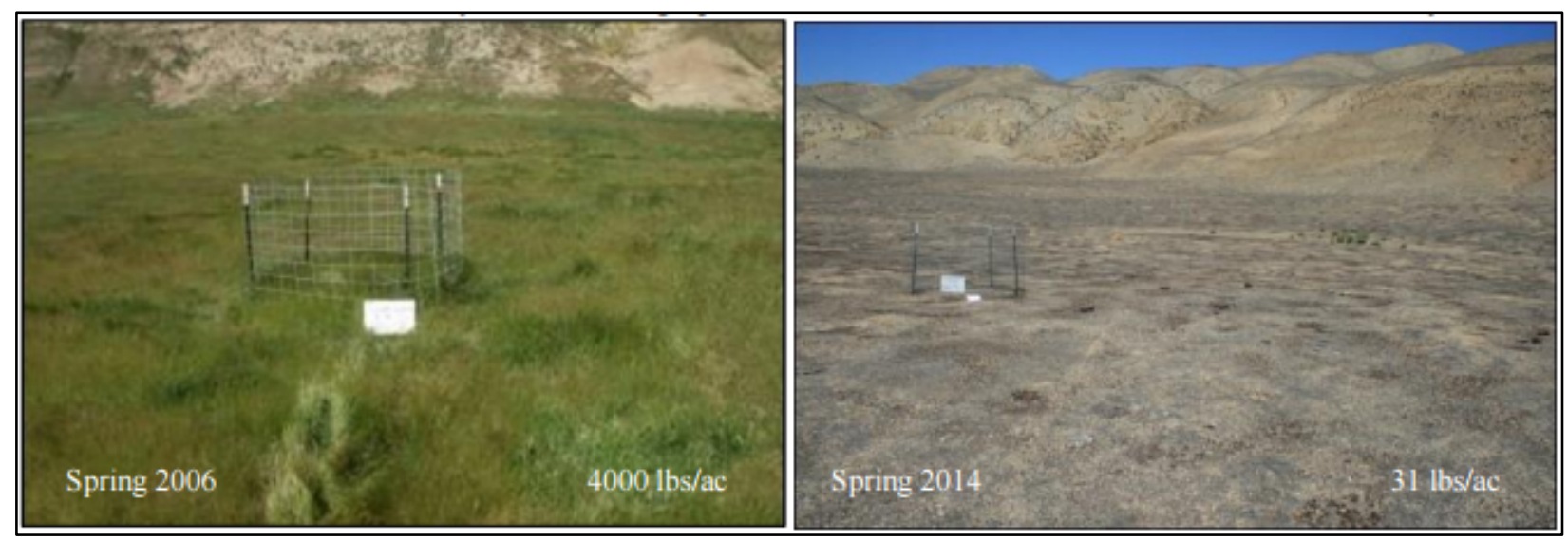

Figure 1.8: Change in forage productivity between a wet and dry year (Battany et al. 2014).

Future climate change could result in more frequent and severe droughts in California. The extent to which these changes will impact rangelands is uncertain. In the next chapter we explore the potential impacts of climate change on rangelands across California under the climate futures predicted by two different climate models. These results will help identify which types of rangeland and geographic areas are more vulnerable to climate change, and they may inform adaptation strategies for maintaining the viability of ranching operations in California into the future.

\section{REFERENCES}

Battany, M., M. Bianchi, S. Dara, M. Gaskell, R. E. Larsen, B. Tietje, and B. Faber. 2014. The 2014 Drought: Impacts on San Luis Obispo County Agriculture. University of California Cooperative Extension San Luis Obispo.

Roche, L. M., T. K. Schohr, J. D. Derner, M. N. Lubell, B. B. Cutts, E. Kachergis, V. T. Eviner, and K. W. Tate. 2015. Sustaining Working Rangelands: Insights from Rancher Decision Making. Rangeland Ecology \& Management 68:383-389.

Spiegal, S., L. Huntsinger, P. Hopkinson, and J. Bartolome. 2016. Range Ecosystems. Pages 835-864 in H. A. Mooney and E. S. Zavaleta, editors. Ecosystems of California. University of California Press, Berkeley, California.

State of California. 1977. Forest and Rangeland Resources Assessment and Policy Act,. Cal. Public Resources Code $\S$ 4789-4789.7.

US Department of the Interior. 2013. Forest and Livestock Grazing. Pages 59-66 Economic Report: Fiscal Year 2012.

USDA Economic Research Service. 2015. Farm Income and Wealth Statistics: Value Added Years by State.

USDA National Agricultural Statistics Service. 1970-2015a. Cattle Inventory Survey.

USDA National Agricultural Statistics Service. 1970-2015b. Sheep and Goat Inventory Survey. 
USDA National Agricultural Statistics Service. 1997. Census of Agriculture: California: State and County Data. National Agricultural Statistics Service, US Department of Agriculture, Washington, DC.

USDA National Agricultural Statistics Service. 2002. Census of Agriculture. National Agricultural Statistics Service, United States Department of Agriculture, Washington, D.C.

USDA National Agricultural Statistics Service. 2007. Census of Agriculture. National Agricultural Statistics Service, United States Department of Agriculture, Washington, D.C.

USDA National Agricultural Statistics Service. 2012a. Census of Agriculture. National Agricultural Statistics Service, United States Department of Agriculture, Washington, D.C.

USDA National Agricultural Statistics Service, P. R.-C. 2012b. California County Agricultural Commissioners' Reports: Crop Year 2011-2012. Sacramento, CA.

USDA National Agricultural Statistics Service, P. R.-C. 2013. California County Agricultural Commissioners' Reports: Crop Year 2012-2013. Sacramento, CA.

USDA Natural Resource Conservation Service. 2003. Livestock Nutrition, Husbandry, and Behavior. Pages 6.1-6.19 National Range and Pasture Handbook. 


\section{Chapter Two: Projected Future Water Stress in Rangelands}

Julian Reyes, Alexandros Xides, Hyeyeong Choe, Jennifer Balachowski, Amber Kerr, and Casey Peters

\section{SUMMARY}

In this chapter, we present potential future climate conditions on California rangelands. We first estimate how climatic water deficit (CWD), an indicator of plant water stress, will change across various rangeland vegetation types. Second, we estimate the exposure of these vegetation types to changing CWD. Exposure describes potential future climate change for a particular vegetation type relative to the range of climate conditions it has experienced in the past (i.e., its climate envelope). Our exposure analysis indicates which locations and vegetation types are likely to be most stressed under future climate conditions. We also present these results in the context of county-level beef cattle inventory to gain further insight into how exposure may impact actual cattle production.

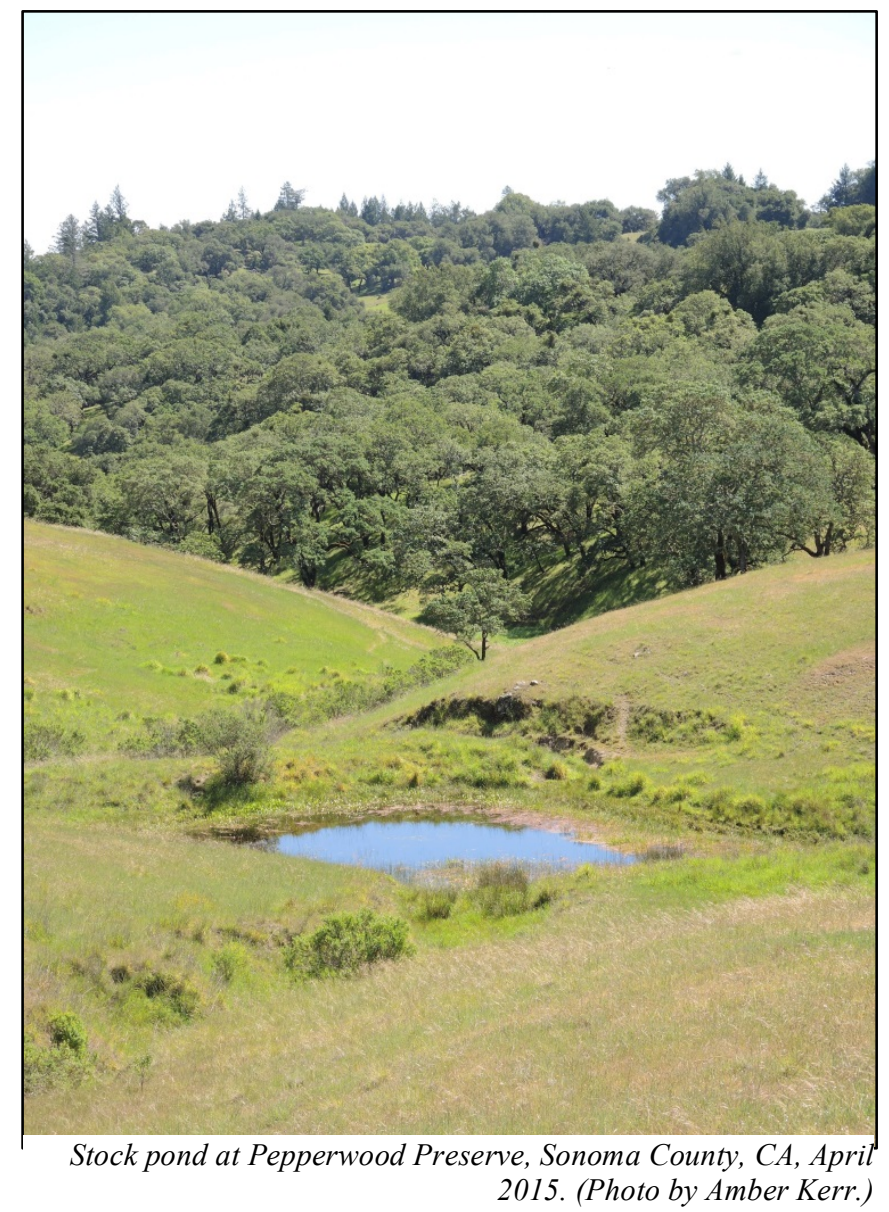

\section{Predicting future Climate Change in California}

Models allow us to assess different pathways of future climate change, or "climate projections" (IPCC 2014). When projecting future climate scenarios, uncertainties related to both future climate variability and to climate model structure lead to multiple realizations, or projections, of the future. It can be useful to compare the output of multiple projections, to consider whether they diverge from or agree with each other, and to use these projections to develop a range of future climate outcomes.

For this report, we used two global climate models (GCMs) to predict future climate conditions for the California landscape from 2040 to 2069. The CNRM CM5 model predicts a future climate for California that is moderately warmer and slightly wetter than current conditions, while the MIROC ESM model predicts a future that is much warmer and significantly drier. 
These two models were chosen because they capture the greatest range of variation in future climate conditions for California (Thorne et al. 2016). Both models were run under a high greenhouse gas emissions scenario-RCP 8.5 - that is considered a 'business-as-usual' future scenario with no particular climate mitigation target (Riahi et al. 2011). We chose this scenario because, as of 2017, actual global emissions have most closely followed RCP 8.5 rather than any of the mitigation-focused scenarios.

The process that we used to generate predictions of future climate is illustrated in Figure 2.1. Both analyses presented in this chapter-1) change in climatic water deficit (CWD) and 2) exposure- compare future projections of California's climate to a baseline period of 1981-2010. In order to calculate change from baseline to future climate conditions within comparable spatial units, we partitioned the California landscape into $270 \mathrm{~m}^{2}$ grid cells, following the methods of Thorne et al. (2016). Climate data (i.e., temperature and precipitation) during the baseline period were obtained from weather station records. Average climate values and variation in those values were estimated by interpolation for each of the $270 \mathrm{~m}^{2}$ grid cells. Downscaled GCMprojected future climate variables (i.e., temperature and precipitation) were also obtained for the same 270 $\mathrm{m}^{2}$ grid cells to which the baseline values were

Figure 2.1: Flow chart for modeling the future change in hydrological variables including climatic water deficit across the California landscape.

Projected Climate Variables Downscaled to $270 \mathrm{~m}^{2}$ grid cells (2040-2069)

Interpolated $270 \mathrm{~m}^{2}$ grid cells (1981-2010)
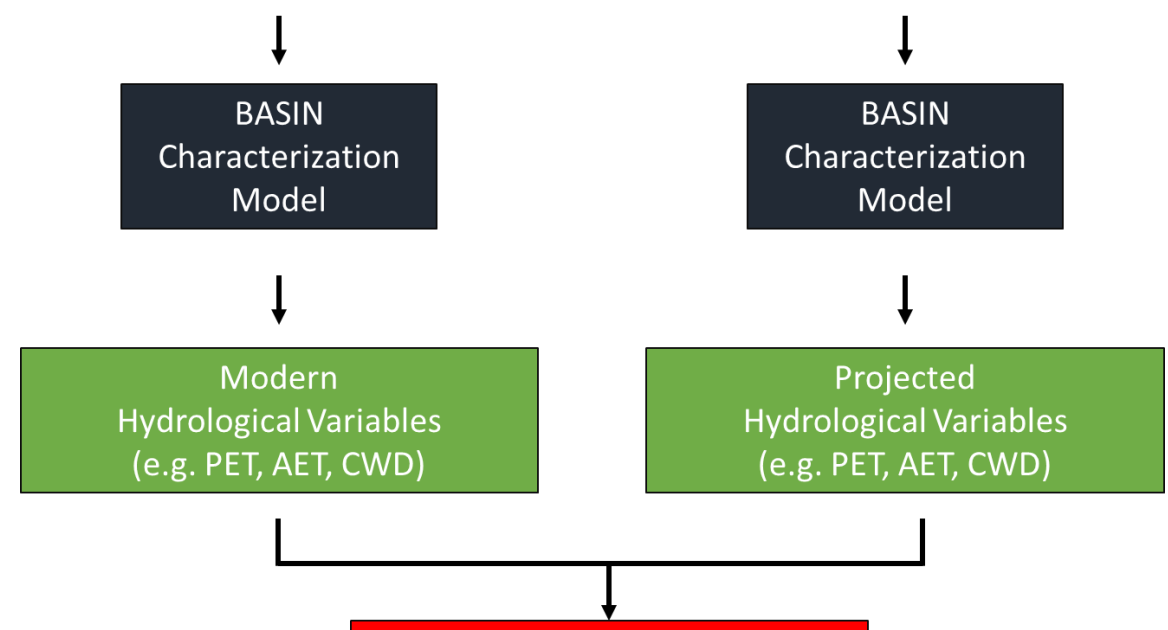

Projected Change in Hydrological

Variables

(e.g. PET, AET, CWD) assigned. 
To predict changes in variables that may be more relevant to rangeland vegetation than average temperature and precipitation, we used the baseline and GCM-projected values (obtained above through interpolation and downscaling) as input to a hydrological model called the Basin Characterization Model (BCM; Flint et al. 2013). The BCM is a process-based model that incorporates biophysical relationships and competing resources. Models like this are useful because they allow us to more accurately reflect how changes in basic climate variables (i.e., temperature and rainfall) may impact ecological processes. We used the BCM to obtain values for hydrologic variables such as CWD, a proxy for plant water stress. Both CWD and the BCM are described further in the following section.

We restricted our analyses to those areas defined as rangelands by the Wildlife Habitat Relationship (WHR) vegetation types designated by the California Department of Forestry and Fire Protection (CAL FIRE). These areas include conifer woodland, desert shrub, desert woodland, hardwood woodland, herbaceous, shrub, and wetland vegetation types (Figure 2.2). Each analysis was run on all land that is classified as rangeland, regardless of whether it is currently grazed (as defined in Chapter 1). 


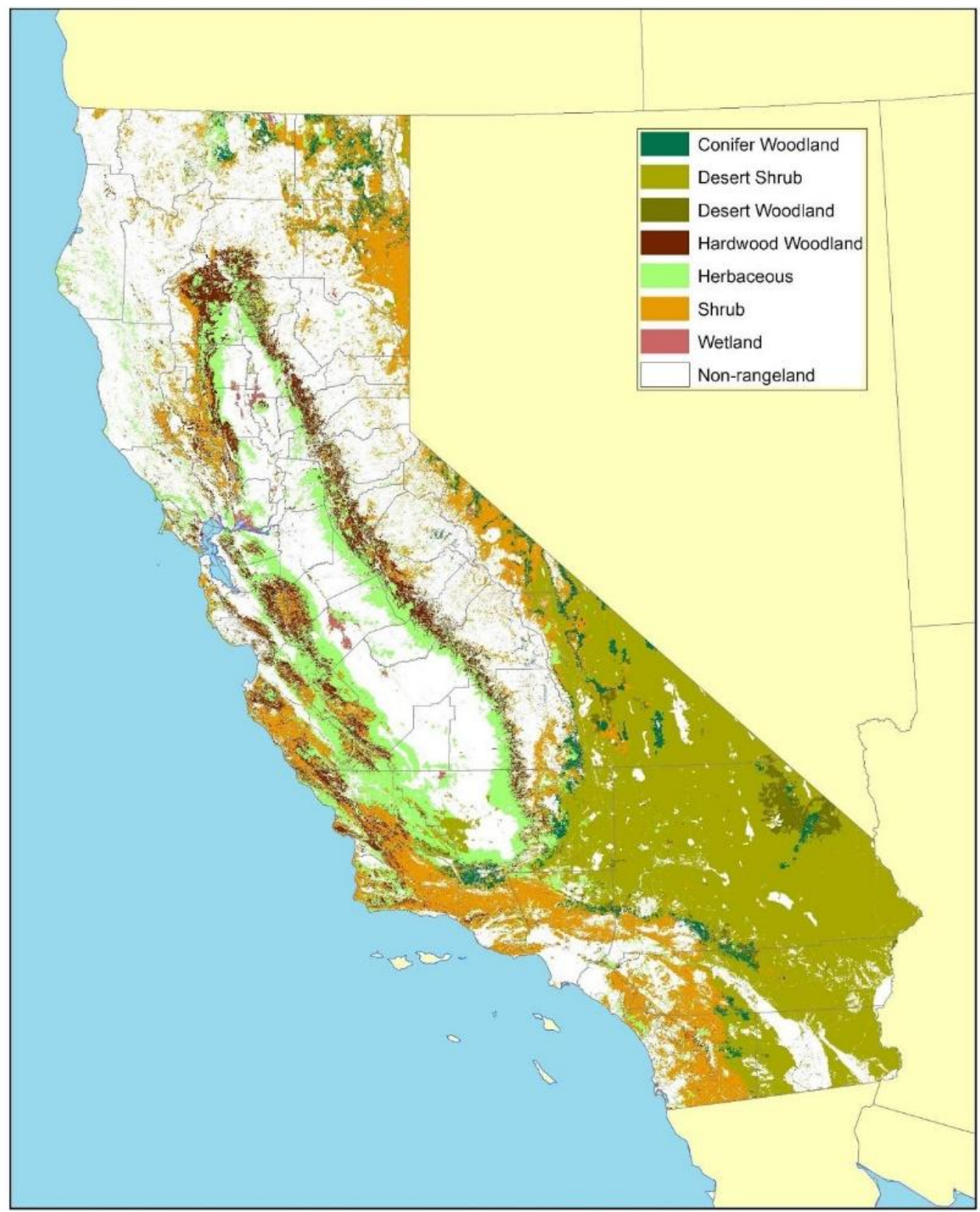

Figure 2.2: Map of current rangeland vegetation types in California.

\section{Change in Climatic Water Deficit}

Climatic water deficit (CWD) is a proxy for landscape water availability. It is calculated as potential evapotranspiration (PET) minus actual evapotranspiration (AET). Evapotranspiration combines evaporation of water into the atmosphere and transpiration of water via plant uptake. PET is the theoretical amount of water that can be lost via evaporation or transpiration, while AET is the actual amount of water that is evaporated or transpired by vegetation. Thus, CWD represents the difference between the amount of water that vegetation can potentially use for growth and the amount of water that is actually available. The minimum possible value of CWD 
is zero, and is obtained when water supply is equal to or exceeds demand. Thus, when CWD is zero, plants are not water stressed. Any positive value of CWD indicates plant water stress and unmet plant growth potential, with higher values of CWD indicating more severe water stress.

Because CWD is based on biophysical relationships driven by environmental factors, changes in CWD can have physiological relevance for rangeland vegetation. CWD can be used to predict potential plant growth and water stress, both of which have implications for forage availability and rangeland sustainability. Though warming temperatures can directly affect livestock health (see Chapter 3) and crop production, this chapter does not consider direct temperature effects, because water availability is usually the key factor limiting productivity in Mediterraneanclimate grasslands.

Annual AET, PET, and CWD were calculated for the baseline 30-year time period (1981-2010) using the BCM (CWD is shown in Fig. 2.3). The BCM simulates the interaction of both temperature and precipitation with landscape attributes such as soil type, topography, and geology. It is a grid-based model that determines the water balance in a particular watershed for given time periods. We calculated baseline hydrological values by running the BCM with baseline temperature and precipitation data (obtained from weather station records, as described above). We calculated future hydrological values using projected climate values from the two GCMs (i.e., CNRM CM5 and MIROC ESM, as described above). We spatially mapped baseline CWD, predicted future CWD, and the predicted change in CWD (i.e., future CWD minus baseline CWD) using a $270 \mathrm{~m}^{2}$ grid cell layer over the state of California. It is important to note that the change in CWD can be negative, indicating less water stress in the future, even though CWD itself is always greater than or equal to zero.

\section{OVERALL CWD RESULTS}

Our results generally corroborate the CWD trends from Thorne et al. (2015), despite the fact that Thorne et al. used different climate models than we did (GFDL: mid-range temperature increase and slight precipitation decrease; PCM: low-range temperature increase and little change in precipitation). We found that the hotter temperature scenario (MIROC) produced higher CWD (Fig. 2.4), similar to the GFDL model (Thorne et al. 2015). While future changes in precipitation are difficult to quantify with high spatial resolution, increases in temperature across California are less spatially variable and will generally result in higher CWD. 


\section{CWD Current}

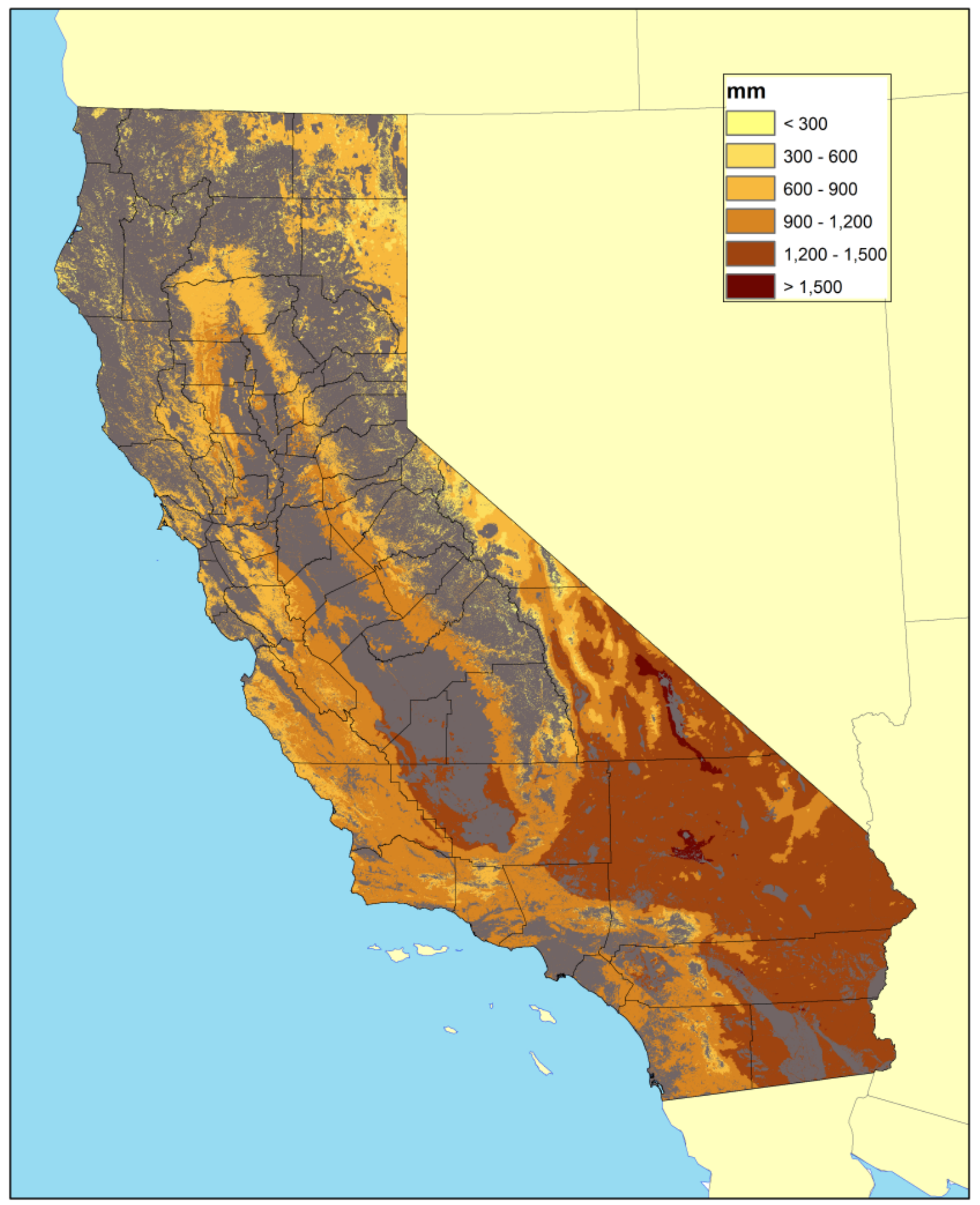

Figure 2.3: Mean baseline climatic water deficit (CWD) for 1981-2010 for rangeland vegetation types (non-gray shaded areas). 
CNRM RCP 8.5
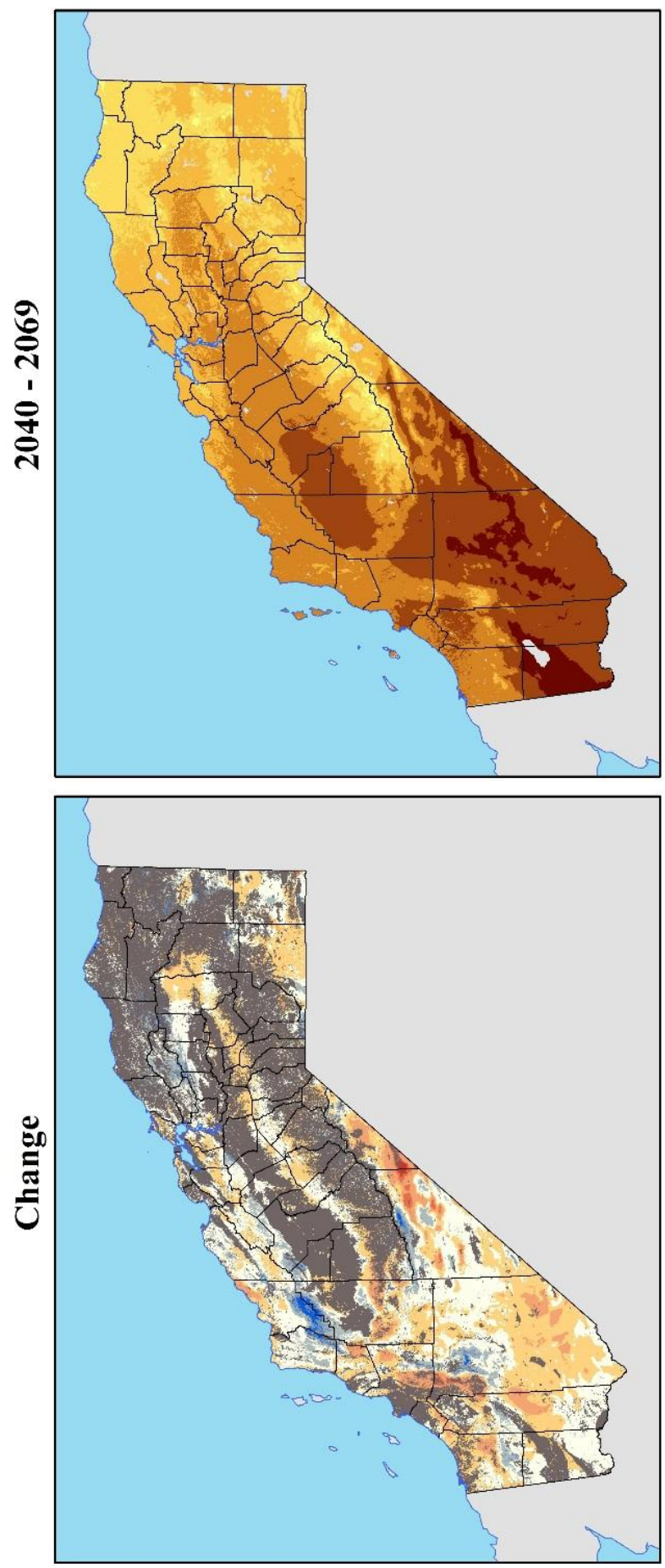

MIROC RCP 8.5
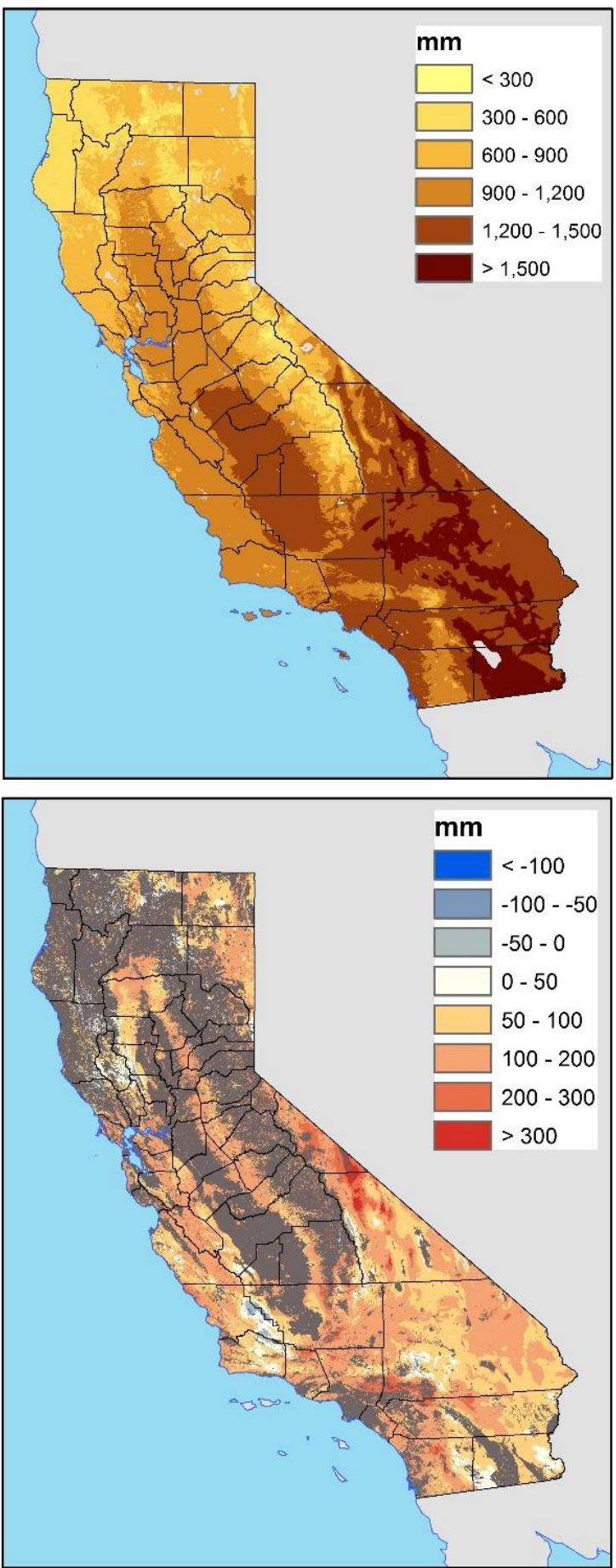

Figure 2.4: Projected total change in annual climatic water deficit (CWD), an indicator of plant water stress. Future CWD was estimated using the CNRM (warm and slightly wetter) and MIROC (hotter and drier) global climate models within the Basin Characterization Model. The top two maps show projected future mean CWD values across the state for 2040-2069, and the bottom maps show the projected mean change from the baseline values (1981-2010). The bottom maps focus on CWD change specifically in rangelands; non-rangeland areas are shaded grey. Cooler colored areas on the lower maps indicate where plant water stress is predicted to decrease in the future, while warmer colored areas indicate where it is predicted to increase. 
DIFFERENCES IN CWD CHANGE BY VEGETATION TYPE

As illustrated in Figure 2.4, the magnitude of change in CWD varies across both rangeland vegetation types and climate models. Most rangelands are projected to experience increases in CWD (i.e., increased plant water stress). Most of California's rangeland vegetation types follow this projected trend of increased CWD under both models (Figure 2.4). At least $80 \%$ of each rangeland vegetation type is projected to experience increased water stress by the 2040-2069 period (Figure 2.4). Desert shrub, shrub, and herbaceous rangelands (i.e., grasslands or prairies) constitute the largest proportions of the total California rangeland area that is projected to experience increased water stress under both models (Figures 2.1 and 2.4).

The implications of increasing CWD for overall rangeland vulnerability are not fully known. They depend on the sensitivity of different vegetation types to water stress (Thorne et al. 2016), the total rangeland acreage each type comprises (see Chapter 1), and their relative level of use by ranchers. Thorne et al. (2016) found desert shrubland to be significantly less sensitive to water stress than other vegetation types even though they constitute the largest percent of total rangeland area affected by CWD increase based on our analysis (Figure 2.4). By contrast, herbaceous vegetation is considered sensitive to precipitation. Despite its smaller affected footprint, grassland is a focus of particular concern in this CWD analysis due to its higher productivity and greater overall importance as a source of forage for California livestock (CAL FIRE FRAP 2003). Desert shrubs, as well as being more intrinsically hardy, may be able to more easily respond to increasing water stress (Reynolds et al. 1999); however, species-specific research on drought effects and response is ongoing (Sperry and Hacke 2002).

\section{DIFFERENCES IN CWD CHANGE BY REGION}

Even the wetter climate model, CNRM, predicts increases in CWD across much of the state, except for CWD decreases along the Coast Ranges and southern Sierra Crest. The drier climate model, MIROC, predicts substantial increases in CWD across most of the state, including areas that are historically important for cattle production (such as the Central Valley and Sierra foothills). Both models predict the greatest increase in CWD east of the Sierra Nevada and in the Transverse Ranges. Perhaps the most visible increase in CWD can be seen in desert shrub rangelands of southern Mono and northern Inyo Counties, both of which fall in the rain shadow of the Sierra Nevada. According to the agricultural commissioners' offices for these two counties, livestock production constitutes $39 \%$ and $55 \%$ of county agricultural revenue respectively (Counties of Inyo and Mono Agriculural Commissioner's Office 2014).

Rangelands dominated by shrub or herbaceous cover in counties with high cattle inventories, such as Modoc, Monterey, and the west side of San Luis Obispo, will likely experience CWD increases. The Sierra foothills, which are dominated by herbaceous and hardwood woodland vegetation, are projected to experience slight to moderate increases in CWD. Similarly, Tehama, which includes lands in the eastern foothills of the Coast Range and the western foothills of the 
Sierra Nevada, will experience water stress in its shrub, herbaceous, and hardwood woodland vegetation.

\section{EXPOSURE ANALYSIS}

Exposure to climate change is defined as the degree to which an ecosystem is expected to experience significant climatic changes (IPCC 2001). It is measured relative to baseline, or historic, climatic conditions (Fellman 2012). We predicted the future exposure of California rangelands to a suite of changing meteorological and hydrologic variables, including CWD.

We calculated exposure following the procedure described by Thorne et al. (2016). Nine hydroclimate variables ${ }^{1}$ from the $\mathrm{BCM}$ were used to define the climate space for each rangeland vegetation type. We then calculated exposure as the projected change in this climate space compared to baseline conditions for the dominant vegetation type in a given $270 \mathrm{~m}^{2}$ grid cell. Each grid cell was given a score based on the extent to which it was projected to depart from its historic baseline conditions. For example, a vegetation type was given an exposure ranking greater than $80 \%$ if its projected future climate was outside the range of historic climate values in $80 \%$ of the grid cells within that vegetation type. Following Thorne et al. (2016), we defined the areas with exposure score rankings greater than $90 \%$ as critically exposed. These areas have a projected future climate currently experienced in only $10 \%$ of the range of their dominant vegetation type.

\section{DIFFERENCES IN EXPOSURE TO CWD CHANGE BY VEGETATION TYPE}

We found that exposure characteristics differed among the seven rangeland types used in this analysis (Figure 2.5; Tables 2.1 and 2.2). Choice of GCM model (i.e., CNRM, MIROC) typically did not change which vegetation type was "most exposed" or "least exposed" (Table 2.1). Total spatial areas at critical exposure also varied among vegetation types, but generally remained similar across GCM models Table 2.1: Vegetation types with the highest and lowest proportions of land cover in the top $25 \%$ of exposure, for each climate model.

\begin{tabular}{lll}
\hline & Most exposed & Least exposed \\
\hline \multirow{2}{*}{ CNRM } & Desert woodland, & Shrub, \\
("Warm and Wet") & $\begin{array}{l}\text { Conifer woodland, } \\
\text { Hardwood woodland }\end{array}$ & $\begin{array}{l}\text { Desert Shrub, } \\
\text { Herbaceous }\end{array}$ \\
\hline \multirow{2}{*}{$\begin{array}{l}\text { MIROC } \\
\text { ("Hot and Dry") }\end{array}$} & Desert woodland, & Shrub, \\
& Hetwood woodland, & Desert Shrub, \\
\end{tabular}

(Table 2.2).

Like percent change in CWD, the level of exposure must be considered in light of differences in vegetation extent and potential for use by ranchers. For example, while desert woodland has the

\footnotetext{
${ }^{1}$ The nine hydro-climate variables to calculate exposure from future climate projections were: annual mean minimum temperature, annual mean maximum temperature, annual precipitation, actual evapotranspiration, potential evapotranspiration, climatic water deficit, April $1^{\text {st }}$ snowpack depth, runoff, and recharge. A principal component analysis (PCA) was used to determine what minimum number of variables could explain most of the variation in future climate projections.
} 
greatest fraction of area in the top $25 \%$ of exposure, the forage production potential of desert woodland is already relatively low. Hardwood woodland shows a similar fraction of critically exposed area, but provides more forage, and thus can support a larger number of livestock than desert woodland. Therefore, the impact of climate exposure on the productivity of various vegetation types is context-dependent, even though the spatial extent of the exposed areas may be similar. Breaking down areas of critical exposure by vegetation type (Table 2.2) provides a baseline to critically analyze how these areas contribute to overall rangeland vulnerability.

\begin{tabular}{|c|c|c|c|c|}
\hline \multirow[b]{2}{*}{ WHR Type } & \multicolumn{2}{|c|}{ CNRM } & \multicolumn{2}{|c|}{ MIROC } \\
\hline & $\begin{array}{c}\text { Area at Critical } \\
\text { Exposure (acres) }\end{array}$ & $\begin{array}{c}\% \text { at Critical } \\
\text { Exposure }\end{array}$ & $\begin{array}{c}\text { Area at Critical } \\
\text { Exposure (acres) }\end{array}$ & $\begin{array}{c}\% \text { at Critical } \\
\text { Exposure }\end{array}$ \\
\hline $\begin{array}{c}\text { Conifer } \\
\text { Woodland } \\
\end{array}$ & 861,139 & $37 \%$ & 661,454 & $28 \%$ \\
\hline Desert Shrub & $7,312,008$ & $33 \%$ & $6,813,310$ & $31 \%$ \\
\hline $\begin{array}{c}\text { Desert } \\
\text { Woodland }\end{array}$ & 909,741 & $87 \%$ & 813,078 & $78 \%$ \\
\hline $\begin{array}{l}\text { Hardwood } \\
\text { Woodland }\end{array}$ & $2,426,083$ & $46 \%$ & $2,541,787$ & $48 \%$ \\
\hline Herbaceous & $3,964,385$ & $36 \%$ & $2,931,825$ & $27 \%$ \\
\hline Shrubland & $2,431,001$ & $16 \%$ & $1,898,653$ & $13 \%$ \\
\hline Wetland & 178,266 & $29 \%$ & 112,371 & $18 \%$ \\
\hline
\end{tabular}

\section{DIFFERENCES IN EXPOSURE TO CWD CHANGE BY REGION}

In both climate scenarios, the Sierra foothills are predicted to be highly exposed. However, the models disagree somewhat on whether the northern Sierra foothills (according to CNRM) or southern Sierra foothills (according to MIROC) will experience higher water stress. By contrast, the Coast Range is not expected to experience the same degree of climate change, and thus appears less exposed in our analysis. Other areas that appear highly exposed in both model projections include the northern tip of the Sacramento Valley (woodland and herbaceous grassland in Shasta and Tehama counties) and the eastern portions of San Bernardino, Riverside, and Imperial Counties (most of which are desert shrub communities). Most of the Coast Range has low exposure across both models, and the shrublands of the High Sierra are characterized by spatially diverse exposure results. 
Although smaller in spatial extent, scattered grasslands and shrublands on the North Coast (Del Norte and Humboldt Counties) are also highly exposed in our analysis. However, because the exposure analysis does not explicitly predict vegetation response, it cannot be ruled out that forage production on the North Coast may actually benefit from warmer, wetter conditions, even though these conditions depart from historical norms and are therefore considered "exposure."

To gain further insight into the extent to which rangeland climate exposure aligns with actual cattle production, we calculated the percentage by area of rangeland within each county that was rated as critically exposed (i.e., an exposure rating greater than $90 \%$ ). We report this calculation for the twenty counties with the highest beef cattle inventories for 2007. This is the most recent year for which beef cattle inventories are available for all producing counties, but we also report 2012 inventories for the counties that have them (Table 2.3).

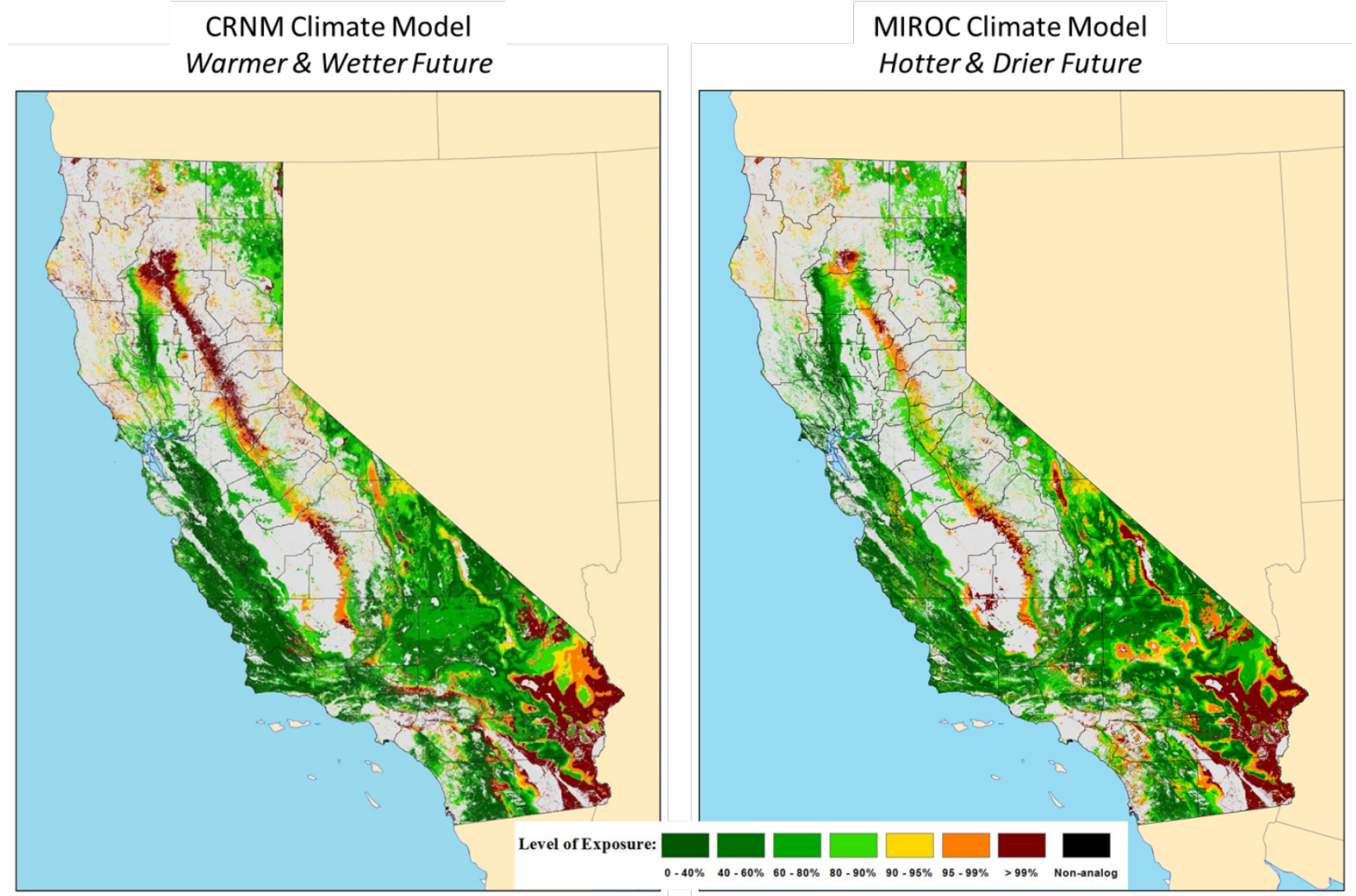

Figure 2.5: Exposure analysis maps for two climate model projections of future climate from 2040-2069. The percentages indicate the extent of climate exposure and are defined relative to the baseline climate within each vegetation type.

Many of the top beef cattle producing counties, such as Modoc and San Luis Obispo, have relatively low percentages of rangeland projected to be critically exposed. Counties with both high cattle production and high proportions of critically exposed rangeland using both models 
include Humboldt, Siskiyou, and Shasta Counties in Northern California, and Madera County in the Sierra foothills. We hope that these preliminary county-by-county results can help prioritize future research that focuses on California's most productive and most vulnerable rangelands.

Table 2.3: The top twenty counties ranked by beef cattle inventory in 2007, and their rankings in terms of the percentage of rangeland rated as critically exposed under future climate projections. The cells are highlighted red if the county falls in the top ten most critically exposed counties, and yellow if it falls in the top 20. A map of California counties is available at www.counties.org/general-information/california-county-map.

\begin{tabular}{|c|c|c|c|c|c|c|c|}
\hline & & & & \multicolumn{2}{|c|}{ CNRM Climate Model } & \multicolumn{2}{|c|}{ MIROC Climate Model } \\
\hline County & $\begin{array}{l}2007 \text { Beef } \\
\text { Cattle } \\
\text { Inventory }\end{array}$ & $\begin{array}{l}2012 \text { Beef } \\
\text { Cattle } \\
\text { Inventory }\end{array}$ & $\begin{array}{c}\text { Total } \\
\text { Rangeland } \\
\text { Acres }\end{array}$ & $\begin{array}{c}\text { Exposure } \\
\text { Rank }\end{array}$ & $\begin{array}{l}\text { Percentage of } \\
\text { Rangeland } \\
\text { with Critical } \\
\text { Exposure }\end{array}$ & $\begin{array}{c}\text { Exposure } \\
\text { Rank }\end{array}$ & $\begin{array}{l}\text { Percentage of } \\
\text { Rangeland } \\
\text { with Critical } \\
\text { Exposure }\end{array}$ \\
\hline MODOC & 45,000 & 34,500 & $1,588,849$ & 28 & $7 \%$ & 34 & $13 \%$ \\
\hline SAN LUIS OBISPO & 35,000 & No Data & $1,866,858$ & 44 & $2 \%$ & 45 & $4 \%$ \\
\hline SISKIYOU & 34,000 & 32,000 & $1,027,102$ & 10 & $22 \%$ & 13 & $52 \%$ \\
\hline STANISLAUS & 34,000 & 36,500 & 467,876 & 49 & $0 \%$ & 33 & $15 \%$ \\
\hline KERN & 31,000 & 32,000 & $3,505,750$ & 28 & $7 \%$ & 26 & $22 \%$ \\
\hline LASSEN & 26,000 & 22,000 & $1,897,536$ & 40 & $3 \%$ & 43 & $5 \%$ \\
\hline TEHAMA & 25,000 & 24,000 & $1,194,433$ & 12 & $21 \%$ & 28 & $21 \%$ \\
\hline TULARE & 25,000 & 28,000 & 972,321 & 28 & $7 \%$ & 18 & $44 \%$ \\
\hline MONTEREY & 24,000 & 20,000 & $1,710,263$ & 49 & $0 \%$ & 39 & $7 \%$ \\
\hline MERCED & 23,000 & 31,500 & 578,230 & 49 & $0 \%$ & 36 & $12 \%$ \\
\hline HUMBOLDT & 20,000 & 17,000 & 330,646 & 4 & $36 \%$ & 2 & $93 \%$ \\
\hline SHASTA & 19,000 & 18,300 & 778,869 & 19 & $14 \%$ & 11 & $56 \%$ \\
\hline SAN BENITO & 19,000 & 12,000 & 789,317 & 49 & $0 \%$ & 37 & $10 \%$ \\
\hline FRESNO & 19,000 & 19,700 & $1,053,438$ & 23 & $9 \%$ & 21 & $38 \%$ \\
\hline SOLANO & 18,000 & No Data & 214,240 & 45 & $1 \%$ & 51 & $0 \%$ \\
\hline GLENN & 17,000 & 12,000 & 414,681 & 40 & $3 \%$ & 45 & $4 \%$ \\
\hline SANTA BARBARA & 17,000 & 15,500 & $1,355,298$ & 45 & $1 \%$ & 47 & $3 \%$ \\
\hline SACRAMENTO & 15,000 & 13,500 & 197,181 & 10 & $22 \%$ & 38 & $9 \%$ \\
\hline MADERA & 14,000 & 19,000 & 429,705 & 8 & $27 \%$ & 9 & $64 \%$ \\
\hline SAN JOAQUIN & 14,000 & 20,000 & 189,741 & 45 & $1 \%$ & 43 & $5 \%$ \\
\hline
\end{tabular}




\section{REFERENCES}

California Department of Forestry and Fire Protection Fire and Resource Assessment Program. 2003. Rangeland Area and Condition. The Changing California: Forest and Range Assessment.

Counties of Inyo and Mono Agriculural Commissioner's Office. 2014. Crop and Livestock Report. Bishop, CA.

Fellman, T. 2012. The assessment of climate change related vulnerability in the agricultural sector: Reviewing coneceptual frameworks.

Flint, L. E., A. L. Flint, J. H. Thorne, and R. Boynton. 2013. Fine-scale hydrologic modeling for regional landscape applications: the California Basin Characterization Model development and performance. Ecological Processes 2:25.

IPCC. 2001. Climate Change 2001: Synthesis Report. A Contribution of Working Groups I, II, and III to the Third Assessment Report of the Intergovernmental Panel on Climate Change. Cambridge University Press, New York, NY.

IPCC. 2014. Climate Change 2014: Synthesis Report. Contribution of Working Groups I, II and III to the Fifth Assessment Report of the Intergovernmental Panel on Climate Change. IPCC, Geneva, Switzerland.

Reynolds, J. F., R. A. Virginia, P. R. Kemp, A. G. de Soyza, and D. C. Tremmel. 1999. Impact of drought on desert shrubs: Effects of seasonality and degree of resource island development. Ecological Monographs 69:69-106.

Riahi, K., S. Rao, V. Krey, C. Cho, V. Chirkov, G. Fischer, G. Kindermann, N. Nakicenovic, and P. Rafaj. 2011. RCP 8.5-A scenario of comparatively high greenhouse gas emissions. Climatic Change 109:33.

Sperry, J. S., and U. G. Hacke. 2002. Desert shrub water relations with respect to soil characteristics and plant functional type. Functional Ecology 16:367-378.

Thorne, J. H., R. M. Boynton, L. E. Flint, and A. L. Flint. 2015. The magnitude and spatial patterns of historical and future hydrologic change in California's watersheds. Ecosphere 6:1-30.

Thorne, J. H., R. M. Boynton, A. J. Holguin, J. A. E. Stewart, and J. Bjorkman. 2016. A climate change vulnerability assessment of California's terrestrial vegetation. California Department of Fish and Wildlife, Sacramento, CA. 


\title{
Chapter Three: Anticipated Climatic and Biophysical Changes
}

\author{
Jennifer Balachowski, Pelayo Alvarez, and Julian Reyes
}

\section{SUMMARY}

This chapter is a summary of research relevant to climate change impacts on the health and function of rangelands in California. We briefly discuss the global assessment of rangelands made by the Intergovernmental Panel on Climate Change (IPCC), along with other national- and regional-scale assessments. We then discuss specific changes projected for California's climate and their potential consequences on rangeland vegetation, ecosystem

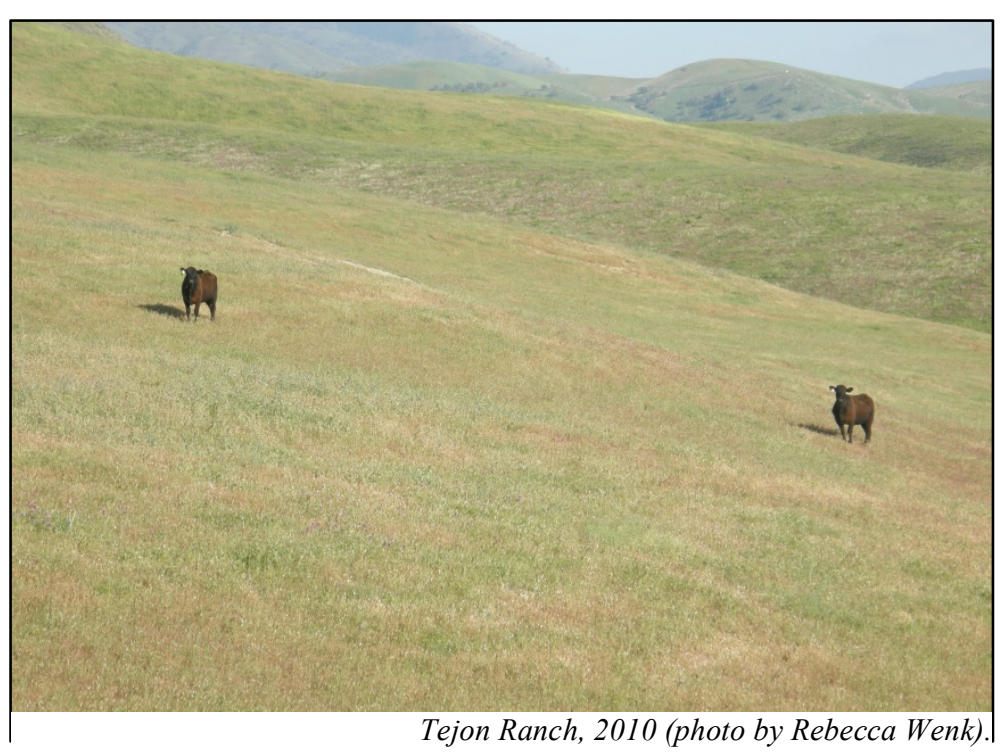
functioning, and livestock health.

\section{THE INTERGOVERNMENTAL PANEL ON CLIMATE CHANGE (IPCC)}

The most recent IPCC Assessment Report (IPCC 2014) identifies climatic changes that threaten rangelands and ranching activities around the world. These changes include increased temperature, increasing frequency and intensity of extreme weather events such as flooding and drought, and increased frequency and intensity of fire. Changes in rangeland productivity, plant species distributions, and community composition are anticipated, which may in turn affect livestock by altering forage quantity or quality. Livestock may also face reduced water availability, increasing risk of heat stress, and greater risk of disease due to increased transmission or distribution of pathogens.

\section{THE NATIONAL CLIMATE ASSESSMENT (NCA)}

The National Climate Assessment (NCA) is a congressionally mandated product of the U.S. Global Change Research Program (USGCRP), a consortium of thirteen federal agencies. The 3rd NCA outlines projected climate change impacts on regions around the United States. The Southwest regional report highlights several interacting climatic changes of particular relevance to California rangelands: reduced snowpack and streamflows, increased drought, and increased wildfire (Table 3.1). 


\begin{tabular}{|c|c|}
\hline $\begin{array}{l}\text { Reduced } \\
\text { snowpack and } \\
\text { streamflows }\end{array}$ & $\begin{array}{l}\text { For the past } 50 \text { years, declines in late winter snowpack across much of the } \\
\text { Southwest region and California have resulted in earlier snowmelt and lower } \\
\text { stream flows. Further reductions in snowpack are anticipated, which will lead to } \\
\text { decreased soil moisture availability in both rangeland and agricultural } \\
\text { ecosystems. }\end{array}$ \\
\hline $\begin{array}{l}\text { Increased } \\
\text { drought }\end{array}$ & $\begin{array}{l}\text { Though the Southwest is historically prone to drought, future droughts are } \\
\text { expected to be hotter, more frequent, and longer-lasting. Because most rangeland } \\
\text { in the region is comprised of unirrigated pasture (that is, they are dependent only } \\
\text { on rainfall for plant water and soil moisture), they are particularly susceptible to } \\
\text { increasing drought stress. }\end{array}$ \\
\hline $\begin{array}{l}\text { Increased } \\
\text { wildfires }\end{array}$ & $\begin{array}{l}\text { Warming, drought, and invasion by non-native grasses make Southwest } \\
\text { rangelands particularly vulnerable to wildfire. In California, models project up to } \\
\text { a } 74 \% \text { increase in burned area by the end of the century, with a potential } \\
\text { doubling in Northern California under a high emissions scenario. }\end{array}$ \\
\hline
\end{tabular}

\section{Climate Change Predictions for California}

Increasing $\mathrm{CO}_{2}$ concentration, increasing temperature, more variable precipitation patterns and the incidence of more extreme events, such as drought and fire are all likely to impact the sustainability of California's rangelands. A brief description of how these abiotic changes will manifest in California is presented in Table 3.2, and further discussion of their potential impacts on rangeland vegetation and livestock follows.

\section{Impacts of Climate Change on California Rangelands}

In the following sections, we detail how the climate and climate-driven changes described in Tables 3.1 and 3.2 will likely impact rangeland vegetation, ecosystem functioning, and livestock health in California. We first discuss the impacts of climate change on vegetation at increasing scales, from changes in individual plant development to landscape-scale shifts in vegetation type and wildfire regimes. Next, we describe how climate-driven changes in ecosystem functioningincluding carbon storage, the nitrogen cycle, and overall soil health-are likely to impact California rangelands. We conclude with the effects of climate change on livestock health, including animal heat stress, and health effects mediated by changes in forage quality and disease incidence. 


\begin{tabular}{|c|c|}
\hline $\begin{array}{c}\text { Climate-related } \\
\text { change }\end{array}$ & Specific effects for California \\
\hline $\begin{array}{l}\text { Increasing } \\
\text { temperatures }\end{array}$ & $\begin{array}{l}\text { Average temperatures are expected to increase. Model projections for } \\
\text { California include a rise in temperature ranging from } 1.7^{\circ} \mathrm{C} \text { to } 3^{\circ} \mathrm{C} \text { under } \\
\text { low emission scenarios, and between } 3.8^{\circ} \mathrm{C} \text { to } 5.8^{\circ} \mathrm{C} \text { under high emission } \\
\text { scenarios (Dukes and Shaw 2007, Cayan et al. } 2008 \text { ), with higher } \\
\text { temperature increases inland than on the coast (Pierce et al. 2013). } \\
\text { Summer temperatures are expected to become markedly hotter, while } \\
\text { winters will be warmer. }\end{array}$ \\
\hline $\begin{array}{c}\text { Increasing } \\
\text { precipitation variability }\end{array}$ & $\begin{array}{l}\text { Precipitation forecasts are less certain than those for temperature, } \\
\text { but in general, inter-annual and seasonal variability are expected to } \\
\text { increase (Dettinger } 2005 \text {, Pierce et al. 2013). In Northern California, } \\
\text { winters will be modestly wetter (1-10\% relative to the 1985-94), while } \\
\text { spring and fall will be drier. Southern California is also likely to have } \\
\text { drier springs and falls, but unlike Northern California, winters will be } \\
\text { drier (1-5\%) and summers wetter (46-59\%) due to the monsoons (Eviner } \\
\text { 2016). Stream flow is also expected to change significantly, with rivers } \\
\text { fed by Sierra Nevada snowpack experiencing higher winter and } \\
\text { decreasing spring and summer flows (Maurer et al. 2007). }\end{array}$ \\
\hline $\begin{array}{l}\text { More frequent and } \\
\text { intense droughts and } \\
\text { more extreme rainfall } \\
\text { events }\end{array}$ & $\begin{array}{l}\text { Drought and extreme rainfall events are expected to increase in } \\
\text { frequency and intensity (Dukes and Shaw 2007, Reever Morghan et al. } \\
\text { 2007, Pierce et al. 2013). Climate change is increasing the probability that } \\
\text { dry years coincide with warmer temperatures, and in turn, that } \\
\text { precipitation deficit will result in severe drought (Diffenbaugh et al. } \\
\text { 2015). Extreme rain events are also likely to increase in frequency and } \\
\text { magnitude, which will challenge the capacity of rangelands to mitigate } \\
\text { flooding. A 10-50\% increase in maximum three-day rainfall accumulation } \\
\text { (a measure of flood potential) is expected by } 2060 \text { (Pierce et al. 2013), } \\
\text { and strong El Niño (ENSO) events, which are typically associated with } \\
\text { above average rainfall, may increase in frequency or intensity (Cai et al. } \\
\text { 2014). }\end{array}$ \\
\hline Increasing wildfire risk & $\begin{array}{l}\text { Wildfires are expected to occur more often throughout the state and } \\
\text { to burn larger areas (Westerling et al. 2011). Projected increases in the } \\
\text { frequency of wildfire occurrence and the percentage of area burned range } \\
\text { from } 41-69 \% \text { by } 2085 \text { (compared to a reference period centered on 1975) } \\
\text { under a high emissions scenario. In dry grass and shrub communities, } \\
\text { above-normal precipitation can result in increased growth of fine fuels, } \\
\text { which can elevate fire risk. Predicting future wildfire risk in these } \\
\text { rangeland vegetation types is thus complicated by uncertainty in modeled } \\
\text { precipitation forecasts (Westerling and Bryant 2006). }\end{array}$ \\
\hline
\end{tabular}




\section{IMPACTS ON VEGETATION}

\section{Plant biological processes and implications for forage production}

Considered alone, $\mathrm{CO}_{2}$ enrichment is expected to increase overall rangeland productivity, as elevated atmospheric $\mathrm{CO}_{2}$ generally results in increased photosynthetic activity and biomass production (Izaurralde et al. 2011). However, the long-term response of plant communities to increased $\mathrm{CO}_{2}$ levels is modulated by other environmental factors such as temperature, precipitation, and nutrient availability. Likewise, the degree of response depends on photosynthetic pathway (Polley et al. 2013). Greater increases in productivity are expected for $\mathrm{C}_{3}$ species, which grow most efficiently during the cooler, wetter season and comprise the majority of current rangeland species and plant biomass found in California (Spiegal et al. 2016). By contrast, little to no $\mathrm{CO}_{2}$ fertilization effect is expected for $\mathrm{C}_{4}$ species, which grow more efficiently during the warmer, sunnier season. The overall effect of $\mathrm{CO}_{2}$ enrichment on productivity in California annual grasslands is not known. The only available field data, from a long-term experiment near Stanford, California, showed that $\mathrm{CO}_{2}$ enrichment alone increased annual grassland net primary productivity, but not when considered in combination with other global changes (increased temperature, precipitation, and $\mathrm{N}$ deposition) (Shaw et al. 2002).

The effects of temperature on plant growth, phenology, and rangeland productivity depend on interactions with precipitation and water

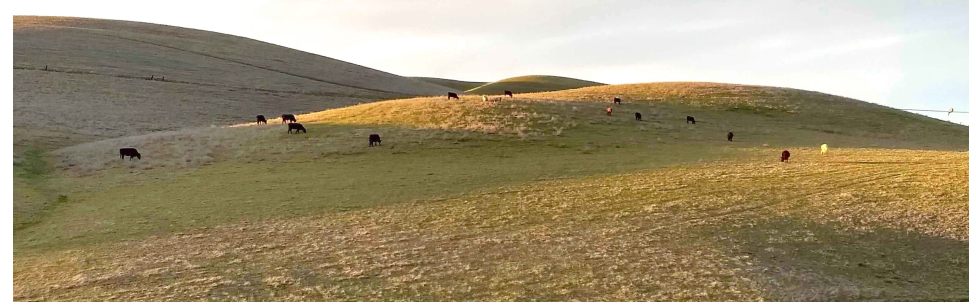
availability (Izaurralde et al. 2011).

Thus, uncertainty in future precipitation forecasts drives much of the uncertainty in predicting how rangeland species will respond to climate change. In general, increasing temperatures result in higher plant metabolism and faster development, leading to earlier green-up, a longer growing season, and increased productivity. However, reduced water availability decreases plant growth, shortens the growing season, and decreases productivity (Briske et al. 2015). When higher temperatures enhance evapotranspiration or increase drought risk in systems (or during seasons) that are already water-limited, increasing temperature and $\mathrm{CO}_{2}$ can result in reduced, rather than enhanced, rangeland productivity (Izaurralde et al. 2011, Briske et al. 2015).

Modeling studies illustrate the complexity of predicting how multiple interacting factorselevated $\mathrm{CO}_{2}$, increasing temperature, and in particular, altered precipitation timing-will influence rangeland productivity and phenology (Shaw et al. 2011, Chaplin-Kramer and George 2013). They also demonstrate that the effects of climate change on rangeland vegetation may vary regionally. For example, a modeling study focused on the San Francisco Bay area found an increase in overall forage production due to warming temperatures during the winter growing 
season (Chaplin-Kramer and George 2013). However, in the same study, altered precipitation patterns shortened the growing season and delayed germination of forage species. By contrast, a second modeling study focused on rangelands across the entire state projected decreases in overall forage production by 2100 , with many of the largest losses due to increases in the extent of shrublands at the expense of grasslands (Shaw et al. 2011). Models with warmer, slightly drier conditions projected losses in forage production concentrated in the inner central coast region and along the foothills of the Sierra Nevada, while models with hotter, drier characteristics predicted dramatic declines in forage productivity across the state (Shaw et al. 2011).

\section{Effects on forage quality: nutrition and digestibility}

Forage quality and palatability may be reduced when plants grow in $\mathrm{CO}_{2}$ enriched environments due to lower $\mathrm{N}$ and mineral concentrations in the leaf (Allen-Diaz et al. 1996, Korner 2002). Lower $\mathrm{N}$ concentrations, in conjunction with accelerated leaf senescence due to water stress, can also reduce forage digestibility and nutritive value (Morgan et al. 2004). In turn, excess carbon may be converted to plant secondary compounds such as tannins, further reducing palatability of forages (Allen-Diaz et al. 1996).

Several additional facets of climate change may interact to reduce rangeland forage quality, including changes to plant phenology, species composition, and water availability (Allen-Diaz et al. 1996, Walther 2003, Craine et al. 2009). In the Southwest, the combination of increased temperatures and reduced precipitation will decrease soil water availability, diminishing not only forage quantity but also nutrient content (Polley et al. 2013). In the Bay Area, forage nutritional quality is projected to decrease due to a shorter growing season, which reduces the amount of time available for forage to produce adequate nutrients (Chaplin-Kramer and George 2013).

\section{Vegetation composition and ecology}

Climate change may alter both the diversity and relative abundances of plant functional types (e.g., grasses, forbs, or woody species; annuals or perennials; native or non-native species) within rangeland plant communities. Outcomes will likely depend on the timing and interaction of multiple climate-related stressors. For example, in a 15-year observational survey of a Northern California grassland community, a decline in species richness (i.e., the total number of species present) was linked to reduced winter moisture availability (Harrison et al. 2015). The trend was driven by losses in native annual forb species, which possessed traits indicative of lower drought tolerance.

A manipulative experiment using realistic combinations of global change stressors had relatively small effects on diversity, but more marked effects on the relative dominance of forbs and grasses (Zavaleta et al. 2003). In this experiment, warming increased forb production and abundance, but did not affect grass production or overall diversity. Elevated $\mathrm{CO}_{2}$ reduced diversity, but had little effect on relative abundance or production of forbs and grasses. Additionally, the study found individual species were more sensitive to inter-annual variability 
and climate extremes than to changes in mean climate conditions. However, other climate manipulation studies on California grasslands have produced contrasting results: for example, Suttle et al. (2007) found that altered precipitation not only changed the relative abundance of forbs and grasses, but that the pattern changed over the five years of the study.

The effects of climate change on rangeland plant community composition is an area of active research inquiry. Additional research is needed to address how climate change may alter biotic interactions within rangeland vegetation communities. Specific areas of concern include interactions among plants (including individuals, species, and functional groups), between plants and their pollinators, and between plants and native and introduced herbivores and plant pathogens (Zavaleta et al. 2003). In addition, further study is needed to address the influence of other potential drivers of shifts in rangeland plant community composition, such as fire and nitrogen deposition (Robison 2009, Fenn et al. 2010).

\section{Shifts in relative abundance of different rangeland vegetation types}

At the landscape scale, climate change may alter the relative extent or distribution of optimal rangeland vegetation types across California. Several simulation studies have predicted overall increases in grassland cover resulting from both decreased moisture and increasing wildfire (Hayhoe et al. 2004, Lenihan et al. 2008). One study in particular found that the underlying cause of increasing grassland cover varied by climate scenario: under a warmer/drier scenario, grassland expansion was due to reduced moisture availability; under a cooler/less dry scenario, it was driven by increased production of fine fuels, which increased fire intensity that in turn reduced cover of (and thus, competition from) woody vegetation (Lenihan et al. 2008).

By contrast, a more recent simulation study using both updated vegetation and fire models predicted an increase in shrub cover at the expense of grassland (Shaw et al. 2011). The updated models predicted more frequent, less intense fires that did not kill woody vegetation, as well as more effective drought survival in shrubs due to increasing water use efficiency with elevated $\mathrm{CO}_{2}$. Forage quantity may thus be reduced as the herbaceous component of rangelands decreases while the shrub component increases.

\section{Invasive plants and noxious rangeland weeds}

Climate change can result in positive or negative effects on invasive species abundance and distribution (see Theoharides and Dukes 2007 and Hellmann et al. 2008 for general overviews of the pathways through which climate change may influence invasion). How plants respond to climate change depends upon their particular traits, not their classification as native, non-native, or invasive. However, invasive species often share common traits that result in similar responses to climate, including more efficient use of resources, higher tolerance for disturbance and fluctuating environmental conditions, and higher reproductive rates (D'Antonio and Vitousek 1992). For example, a modeling study using California herbarium records to indicate optimal climate conditions for different rangeland grasses found that warming is likely to favor species 
with faster growth, and in California rangelands, these tend to be invasive annual grasses rather than native perennials (Sandel and Dangremond 2012).

Several studies have demonstrated the effects of global change-including elevated $\mathrm{CO}_{2}$, changes in precipitation patterns, and altered wildfire regimes - on the growth and ecology of invasive rangeland plants. For instance, $\mathrm{CO}_{2}$ enrichment in the Mojave Desert resulted in a greater increase in productivity of invasive red brome (Bromus rubens) than in several native grass species (Smith et al. 2000). A similar response explains the success of cheatgrass (Bromus tectorum) across large tracts of western North American rangeland (Strain and Smith 1985). In California, drought and livestock grazing pressure have favored annual exotic species, and have likely contributed to the loss of the majority of native perennial grasslands (Jackson 1985, Everard et al. 2010).

Precipitation timing will likely be an important determinant of the relative abundances of native and invasive rangeland grasses, and may provide new opportunities for restoration. Late-season rainfall usually benefits later-maturing invaders, such as goat grass, Medusahead (Taeniatherum caput-medusae) and yellow starthistle (Centaurea solstitialis), while drier growing seasons causes them to decline (Eviner et al 2014). Many native perennial grasses overlap in phenology with late-season noxious weeds: they are resilient to short-term droughts, but also benefit from late-season rainfall (Reever Morghan et al. 2007). As a result, perennial grasses are likely to establish and persist under fluctuating conditions, providing control of priority noxious weeds during years with late-season rainfall (Eviner et al. 2013).

How climate change will influence the distribution and impacts of existing and arriving exotic species is an important topic for future research (Clements and Ditommaso 2011). In support of these efforts, the California Invasive Plant Council (Cal-IPC) has identified several research priorities in invasive species ecology and management with a particular focus on climate change (Robison 2009): 1) incorporating interactive effects of elevated $\mathrm{CO}_{2}$, temperature and moisture changes into predictive models of invasive species distributions; 2) developing models to determine acceptable thresholds of invasive plants in rangelands; and 3) developing modeling tools that land managers can use to inform adaptive management.

Fire regimes and regional wildfire risk

Wildfire risk is generally expected to increase across California under future climate conditions (see Tables 3.1 and 3.2), with the increase expected to be strongest in Northern California and more uncertain in Southern California (Westerling and Bryant 2006). Differences in risk predictions between Northern and Southern California arise from both regional variation in climate model outputs and regional differences in fire regimes. In wetter forested areas like those in Northern California, wildfire risk is determined primarily by the flammability of existing vegetation (an "energy-limited" fire regime). Thus, in Northern California, a hotter climate is 
expected to increase wildfire risk from $40 \%$ (under hotter and wetter future scenarios) to $90 \%$ (under hotter and drier scenarios) by the end of the century (Westerling and Bryant 2006).

By contrast, wildfire risk in drier Southern California grasslands and shrublands tends to depend on the growth of new fine fuels, and is thus sensitive to changes in both temperature and precipitation (a "fuel-limited" fire regime). In Southern California, hotter, drier conditions may result in reduced fire risk in some locations and increased risk in others, with wildfire risk predictions ranging from a $29 \%$ decrease to a $28 \%$ increase, depending on precipitation.

Climate change can also establish feedback cycles between plants and wildfire that are particularly important for California and other rangelands in western North America. For example, increased abundance of invasive cheatgrass has been shown to alter rangeland fuel properties, which in turn affects fire behavior and regime characteristics, such as frequency, intensity, extent, type, and seasonality (Balch et al. 2013). When fire regime changes further promote the dominance of invasive species, as with cheatgrass, an invasive plant-fire regime feedback cycle is established.

\section{IMPACTS ON OTHER ASPECTS OF ECOSYSTEM FUNCTIONING}

\section{Carbon storage potential}

California's rangelands have the capacity to store significant amounts of soil carbon (Silver et al. 2010). Climate has a strong influence on whether California's grasslands will be carbon neutral, weak carbon sources, or weak carbon sinks (Xu and Baldocchi 2004, Ma et al. 2007). The impacts of climate change on carbon budgets in California were simulated under several different climate scenarios (Lenihan et al. 2008). These simulations showed that cooler, wetter conditions yielded a net increase in ecosystem carbon (i.e., carbon uptake from net primary production, deposited into vegetation and soils, exceeded carbon loss through decomposition and fire) (Lenihan et al. 2008). By contrast, a warmer, drier future resulted in a loss of carbon from the ecosystem. In addition, if plant nitrogen uptake is accelerated by increased atmospheric $\mathrm{CO}_{2}$, this can limit the amount of nitrogen available for soil microbes. Taking into account other competing factors, decreases in microbial activity can result in increased carbon storage due to slower decomposition of vegetation (Hu et al. 2001).

\section{Soil health and the nitrogen cycle}

The human-induced increase of reactive nitrogen in agricultural and natural ecosystems can be attributed primarily to an exponential increase in use of nitrogenous fertilizers since the end of the $19^{\text {th }}$ century for growing animal feed and food (Galloway et al. 2003). The impacts of more environmental nitrogen (from runoff or deposition) can have competing feedbacks related to increasing atmospheric $\mathrm{CO}_{2}$.

Though elevated $\mathrm{CO}_{2}$ in isolation is generally expected to increase rangeland productivity, many rangelands are mostly $\mathrm{N}$-limited, and as a result, long-term increases in productivity will depend 
on interactions between climate change and nitrogen cycling. The effects of climate change on nitrogen cycling will be mediated by plants and by litter decomposing soil microbes, resulting in changes to the flux between plant-available and unavailable nitrogen (Luo et al. 2004, Izaurralde et al. 2011). With increasing $\mathrm{CO}_{2}$, progressive nitrogen limitation (PNL) can occur, which ultimately results in less $\mathrm{N}$ available for plant growth and uptake regardless of current nitrogen availability. This effect can occur via two pathways: 1) through sequestration of nitrogen in more recalcitrant, slow-turnover carbon pools in soils, or 2) by increased plant productivity resulting in more carbon and nitrogen sequestered in aboveground plant tissues (Luo et al. 2004).

Simulation studies and historical data suggest that elevated $\mathrm{CO}_{2}$ can lead to increases in $\mathrm{N}$ fixation and soil $\mathrm{N}$ mineralization, decreasing soil $\mathrm{N}$ losses, and decreasing $\mathrm{N}$ concentrations in plant shoots (Polley et al. 2011). Climate change can influence microbial decomposition rates through the indirect effects of elevated $\mathrm{CO}_{2}$ on plants, as well as the direct effects of increasing soil temperatures and changes in soil water availability on microbial physiology and community composition (Izaurralde et al. 2011). In addition, grasslands subjected to annual fires may suffer from decreasing soil organic matter and a long-term loss of nitrogen (Allen-Diaz 1995).

Presently, the degree of these changes is not well known, and may be location-specific. However, synthesizing available evidence suggests that, in general, the effect of elevated $\mathrm{CO}_{2}$ concentration on rangeland productivity may be limited by nitrogen (Izaurralde et al. 2011). A short-term study conducted near Palo Alto, $\mathrm{CA}$ found that enhanced $\mathrm{CO}_{2}$ increased $\mathrm{N}$ mineralization, spurring plant $\mathrm{N}$ uptake and growth (Hungate et al. 1996). While this study considered increased soil moisture as the mechanism for increased $\mathrm{N}$ availability (via $\mathrm{N}$ mineralization), it did not rule out long-term effects such as PNL (Luo et al. 2004).

Most of the well-documented cases of terrestrial ecosystem responses to chronic $\mathrm{N}$ deposition in the western United States are from California (Fenn et al. 2003). Chaparral ecosystems located in the Transverse Ranges in Southern California and near the Sierra Nevada range, as well as coastal sage scrub communities in Southern California, have shown $\mathrm{N}$ enrichment in both the soil and vegetation (Fenn et al. 2003). Nitrogen enrichment has also been linked to the spread of invasive plant species and altered fire cycles in Southern California coastal grasslands (Fenn et al. 2003).

\section{IMPACTS ON LIVESTOCK HEALTH AND MANAGEMENT}

Climate change can impact livestock health directly (e.g., heat stress, decreased water availability) and indirectly (e.g, reduced forage quality, increased parasite abundance). While there are some examples of California-specific research on indirect impacts of climate on livestock health, there are almost no references on direct impacts specific to California rangelands (as of this writing). Thus, in the following sections, we synthesize general information on the effects of climate on livestock health (reviewed by Nardone et al. 2010) with 
climate change expectations (see Tables 3.1 and 3.2) and management considerations that are specific to California.

\section{Livestock heat stress}

Higher temperatures projected for California may result in more frequent livestock heat stress, and extreme conditions can also cause higher livestock mortality (Nienaber and Hahn 2007). More frequent heat stress can adversely affect livestock performance by decreasing forage intake, milk production, and the efficiency of feed conversion (National Research Council 1987, Dumont et al. 2015), and by lowering reproductive efficiency rates (Hansen 2009). In California, most research on cattle heat stress has focused not on rangelands but on dairies and feedlots in the Central Valley, where heat stress can be severe and interventions such as shade shelters and misting machines are common (Stull et al. 2007). Little research has been done in California or elsewhere on the direct effects of shade trees in rangelands, though their benefit to livestock is commonly believed to be significant (Sharrow 2000).

\section{Changes in water availability}

Surface water availability is generally expected to decrease with warming due to higher rates of evapotranspiration and reduced snowpack (Thorne et al. 2015). In general, any factors that decrease water consumption by livestock reduce their intake of forage (National Research Council 1987). Decreased surface water availability can also result in reduced forage digestibility, and in livestock having to travel greater distances to reach water or having to spend more time near water and shade. Stock ponds will become increasingly important as a means to store water in wet years to be used in dry years. They can also provide essential habitat for several endangered amphibian species, including the California red-legged frog and the California tiger salamander (USFWS 2006). However, higher rates of evaporation may affect their ability to store water and provide habitat for wildlife.

\section{Changes in forage quality and quantity}

Livestock performance will be influenced by changes in forage quantity and quality (which are discussed above). Typically, dry matter intake decreases with less protein in the actual forage being eaten across different diet types (National Research Council 1987). In native rangelands and semi-natural grasslands where $\mathrm{N}$ is typically limiting, the constraints of reduced $\mathrm{N}$ and increased fiber in $\mathrm{CO}_{2}$-enriched forage may reduce digestibility and have a negative impact on ruminant performance (Owensby et al. 1996, Korner 2002, Morgan et al. 2004). The National Research Council (1987) reports that digestibility is reduced if rumen bacteria are not provided adequate $\mathrm{N}$ for their functional operation. Additionally, forage quality plays a role in maximum microbial growth since it is primarily a function of how much digestible organic matter is present in the forage, feed, or dry matter ingested (Van Soest 1982, National Research Council 1987).

\section{PARASITES AND DISEASE}

The effects of climate change on livestock health have been reviewed by Heffernan et al. (2012) and by Slenning (2010). Rising temperatures can impact parasites and livestock disease vectors 
by increasing population abundances, shifting or expanding ranges, and accelerating life cycles. For example, increased winter survival and abundance of ectoparasites like horn flies and ticks are expected due to increased average ground and air temperatures, which can reduce livestock performance (Polley et al. 2013). Warmer nights and winters can also shift the ranges of key disease vectors, like mosquitos, northwards, as well as increase biting activity, thus increasing disease transmission rates (Epstein 2001). Several studies also suggest that vector-borne diseases affecting range livestock (e.g., blue-tongue, rift valley fever) can emerge or increase their incidence due to climate change (Konrad and Miller 2012, Rolin et al. 2013).

Changes in both precipitation patterns and the management strategies enacted to cope with reduced water availability can also influence livestock disease incidence. For example, mosquito habitat may increase in areas experiencing greater drought frequency, as running water is reduced to standing pools or as reduced precipitation forces increased reliance on water storage (Patz et al. 2003). In addition, green-blue algae (cyanobacteria) blooms that are potentially toxic to livestock may increase, as blooms can be exacerbated by periods of heavy rainfall followed by drought (Paerl and Paul 2012). Livestock with access to ponds and portions of lakes may be at risk of exposure during toxic blooms, especially when wind-driven surface blooms accumulate at water access sites or in pastures (Stewart et al. 2008).

\section{REFERENCES}

Allen-Diaz, B., F. S. Chapin, S. Diaz, M. Howden, J. Puigdefabregas, and M. S. Smith. 1996.

Rangelands in a Changing Climate: Impacts, Adaptations, and Mitigation. Pages 131-158 Climate Change 1995 : Impacts, Adaptations and Mitigation of Climate Change: Scientific-Technical Analyses. Cambridge University Press, Cambridge.

Balch, J. K., B. A. Bradley, C. M. D'Antonio, and J. Gómez-Dans. 2013. Introduced annual grass increases regional fire activity across the arid western USA (1980-2009). Global Change Biology 19:173-183.

Briske, D. D., L. A. Joyce, H. W. Polley, J. R. Brown, K. Wolter, J. A. Morgan, B. A. McCarl, and D. W. Bailey. 2015. Climate-change adaptation on rangelands: linking regional exposure with diverse adaptive capacity. Frontiers in Ecology and the Environment 13:249-256.

Cai, W., S. Borlace, M. Lengaigne, P. van Rensch, M. Collins, G. Vecchi, A. Timmermann, A. Santoso, M. J. McPhaden, L. Wu, M. H. England, G. Wang, E. Guilyardi, and F.-F. Jin. 2014. Increasing frequency of extreme El Nino events due to greenhouse warming. Nature Clim. Change 4:111-116.

Cayan, D. R., E. P. Maurer, M. D. Dettinger, M. Tyree, and K. Hayhoe. 2008. Climate change scenarios for the California region. Climatic Change 87:21-42.

Chaplin-Kramer, R., and M. R. George. 2013. Effects of climate change on range forage production in the San Francisco Bay Area. PLoS One 8: 57723. 
Clements, D. R., and A. Ditommaso. 2011. Climate change and weed adaptation: can evolution of invasive plants lead to greater range expansion than forecasted? Weed Research 51:227-240.

Craine, J. M., A. J. Elmore, M. P. Aidar, M. Bustamante, T. E. Dawson, E. A. Hobbie, A. Kahmen, M. C. Mack, K. K. McLauchlan, A. Michelsen, G. B. Nardoto, L. H. Pardo, J. Penuelas, P. B. Reich, E. A. Schuur, W. D. Stock, P. H. Templer, R. A. Virginia, J. M. Welker, and I. J. Wright. 2009. Global patterns of foliar nitrogen isotopes and their relationships with climate, mycorrhizal fungi, foliar nutrient concentrations, and nitrogen availability. New Phytol 183:980-992.

D'Antonio, C., and P. Vitousek. 1992. Biological invasions by exotic grasses, the grass/fire cycle, and global change. Annual Review of Ecology and Systematics 23:63-87.

Dettinger, M. D. 2005. From Climate-change Spaghetti to Climate-change Distributions for 21stCentury California. San Francisco Estuary and Watershed Science 3.

Diffenbaugh, N. S., D. L. Swain, and D. Touma. 2015. Anthropogenic warming has increased drought risk in California. Proceedings of the National Academy of Sciences 112:39313936.

Dukes, J. S., and M. R. Shaw. 2007. Responses to changing atmosphere and climate. Pages 218229 in M. R. Stromberg, J. Corbin, and C. D'Antonio, editors. California Grasslands: Ecology and Management. University of California Press, Berkeley, California.

Dumont, B., D. Andueza, V. Niderkorn, A. Lüscher, C. Porqueddu, and C. Picon-Cochard. 2015. A meta-analysis of climate change effects on forage quality in grasslands: specificities of mountain and Mediterranean areas. Grass and Forage Science 70:239-254.

Epstein, P. R. 2001. Climate change and emerging infectious diseases. Microbes and Infection 3:747-754.

Everard, K., E. W. Seabloom, W. S. Harpole, and C. de Mazancourt. 2010. Plant water use affects competition for nitrogen: why drought favors invasive species in California. Am Nat 175:85-97.

Eviner, V. 2016. Grasslands.in H. A. Mooney and E. S. Zavaleta, editors. Ecosystems of California. University of California Press, Berkeley, California.

Eviner, V. T., J. Heraty, J. Baty, C. Mamlstrom, and K. J. Rice. 2013. Impacts of native vs. exotic vegetation. California Invasive Plant Council News 21:13-14.

Fenn, M. E., E. B. Allen, S. B. Weiss, S. Jovan, L. H. Geiser, G. S. Tonnesen, R. F. Johnson, L. E. Rao, B. S. Gimeno, F. Yuan, T. Meixner, and A. Bytnerowicz. 2010. Nitrogen critical loads and management alternatives for $\mathrm{N}$-impacted ecosystems in California. J Environ Manage 91:2404-2423.

Fenn, M. E., J. S. Baron, E. B. Allen, H. M. Rueth, K. R. Nydick, L. Geiser, W. D. Bowman, J. O. Sickman, T. Meixner, and D. W. Johnson. 2003. Ecological effects of nitrogen deposition in the western United States. BioScience 53:404-420.

Galloway, J. N., J. D. Abner, J. W. Erisman, S. P. Seitzinger, R. W. howarth, E. B. Cowling, B. J. Cosby. 2013. The nitroen cascade. BioScience 53:341-356.

Galloway, J. N., F. J. Dentener, D. G. Capone, E. W. Boyer, R. W. Howarth, S. P. Seitzinger, G. P. Asner, C. Cleveland, P. Green, and E. Holland. 2004. Nitrogen cycles: past, present, and future. Biogeochemistry 70:153-226.Hansen, P. J. 2009. Effects of heat stress on mammalian reproduction. Philosophical Transactions of the Royal Society B: Biological Sciences 364:3341-3350. 
Harrison, S. P., E. S. Gornish, and S. Copeland. 2015. Climate-driven diversity loss in a grassland community. Proceedings of the National Academy of Sciences 112:8672-8677.

Hayhoe, K., D. Cayan, C. B. Field, P. C. Frumhoff, E. P. Maurer, N. L. Miller, S. C. Moser, S. H. Schneider, K. N. Cahill, and E. E. Cleland. 2004. Emissions pathways, climate change, and impacts on California. Proceedings of the National Academy of Sciences of the United States of America 101:12422-12427.

Heffernan, C., M. Salman, and L. York. 2012. Livestock infectious disease and climate change: a review of selected literature.

Hellmann, J. J., J. E. Byers, B. G. Bierwagen, and J. S. Dukes. 2008. Five potential consequences of climate change for invasive species. Conserv Biol 22:534-543.

Hu, S., F. S. Chapin, M. Firestone, C. Field, and N. Chiariello. 2001. Nitrogen limitation of microbial decomposition in a grassland under elevated CO2. Nature 409:188-191.

Hungate, B., F. Chapin Iii, H. Zhong, E. Holland, and C. Field. 1996. Stimulation of grassland nitrogen cycling under carbon dioxide enrichment. Oecologia 109:149-153.

IPCC. 2014. Climate Change 2014: Synthesis Report. Contribution of Working Groups I, II and III to the Fifth Assessment Report of the Intergovernmental Panel on Climate Change. IPCC, Geneva, Switzerland.

Izaurralde, R. C., A. M. Thomson, J. Morgan, P. Fay, H. Polley, and J. L. Hatfield. 2011. Climate impacts on agriculture: implications for forage and rangeland production. Agronomy Journal 103:371-381.

Jackson, L. E. 1985. Ecological Origins of California's Mediterranean Grasses. Journal of Biogeography 12:349-361.

Konrad, S. K., and S. N. Miller. 2012. A temperature-limited assessment of the risk of Rift Valley fever transmission and establishment in the continental United States of America. 2012 6:10.

Korner, C. 2002. Grasslands in a $\mathrm{CO}_{2}$ enriched world. Grassland Science Europe 7:611-624.

Lenihan, J. M., D. Bachelet, R. P. Neilson, and R. Drapek. 2008. Response of vegetation distribution, ecosystem productivity, and fire to climate change scenarios for California. Climatic Change 87:215-230.

Luo, Y., B. Su, W. S. Currie, J. S. Dukes, A. Finzi, U. Hartwig, B. Hungate, R. E. Mc Murtrie, R. Oren, and W. J. Parton. 2004. Progressive nitrogen limitation of ecosystem responses to rising atmospheric carbon dioxide. Bioscience 54:731-739.

Ma, S., D. D. Baldocchi, L. Xu, and T. Hehn. 2007. Inter-annual variability in carbon dioxide exchange of an oak/grass savanna and open grassland in California. Agricultural and Forest Meteorology 147:157-171.

Maurer, E. P., I. T. Stewart, C. Bonfils, P. B. Duffy, and D. Cayan. 2007. Detection, attribution, and sensitivity of trends toward earlier streamflow in the Sierra Nevada. Journal of Geophysical Research: Atmospheres 112:n/a-n/a.

Melillo, J. M., T. C. Richmond, and G. W. Yohe, editors. 2014. Climate change impacts in the United States: The third national climate assessment. U.S. Global Change Research Program.

Morgan, J. A., A. R. Mosier, D. G. Milchunas, D. R. LeCain, J. A. Nelson, and W. J. Parton. 2004. $\mathrm{CO}_{2}$ enhances productivity, alters species composition, and reduces digestibility of shortgrass steppe vegetation. Ecological Applications 14:208-219. 
Nardone, A., B. Ronchi, N. Lacetera, M. S. Ranieri, and U. Bernabucci. 2010. Effects of climate changes on animal production and sustainability of livestock systems. Livestock Science 130:57-69.

National Research Council. 1987. Predicting Feed Intake of Food-Producing Animals. Page 96. The National Academies Press, Washington, DC.

Nienaber, J. A., and G. L. Hahn. 2007. Livestock production system management responses to thermal challenges. International Journal of Biometeorology 52:149-157.

Owensby, C. E., R. M. Cochran, and L. M. Auen. 1996. Effects of Elevated Carbon Dioxide on Forage Quality for Ruminants. Pages 363-371 in C. Koerner and F. Bazzaz, editors. Carbon Dioxide, Populations, and Communities. Academic Press, San Diego, California.

Paerl, H. W., and V. J. Paul. 2012. Climate change: links to global expansion of harmful cyanobacteria. Water research 46:1349-1363.

Patz, J., A. Githeko, J. McCarty, S. Hussein, U. Confalonieri, and N. De Wet. 2003. Climate change and infectious diseases. Climate change and human health: risks and responses:103-132.

Pierce, D. W., T. Das, D. R. Cayan, E. P. Maurer, N. L. Miller, Y. Bao, M. Kanamitsu, K. Yoshimura, M. A. Snyder, and L. C. Sloan. 2013. Probabilistic estimates of future changes in California temperature and precipitation using statistical and dynamical downscaling. Climate Dynamics 40:839-856.

Polley, H., J. Morgan, and P. Fay. 2011. Application of a conceptual framework to interpret variability in rangeland responses to atmospheric $\mathrm{CO} 2$ enrichment. The Journal of Agricultural Science 149:1-14.

Polley, H. W., D. D. Briske, J. A. Morgan, K. Wolter, D. W. Bailey, and J. R. Brown. 2013. Climate Change and North American Rangelands: Trends, Projections, and Implications. Rangeland Ecology \& Management 66:493-511.

Reever Morghan, K., J. Corbin, and J. D. Gerlach. 2007. Water relations. Pages 87-93 in M. R. Stromberg, J. Corbin, and C. D'Antonio, editors. California Grasslands: Ecology and Management. University of California Press, Berkeley, California.

Robison, R. 2009. Research needs for invasive plants in California. California Invasive Plant Council, Berkeley, California.

Rolin, A. I., L. Berrang-Ford, and M. A. Kulkarni. 2013. The risk of Rift Valley fever virus introduction and establishment in the United States and European Union. Emerging Microbes \& Infections 2:e81.

Sandel, B., and E. M. Dangremond. 2012. Climate change and the invasion of California by grasses. Global Change Biology 18:277-289.

Sharrow, S. 2000. Trees in pastures: Do cattle benefit from shade? Temperate Agroforester 8:1.

Shaw, M. R., L. Pendleton, D. R. Cameron, B. Morris, D. Bachelet, K. Klausmeyer, J. MacKenzie, D. R. Conklin, G. N. Bratman, J. Lenihan, E. Haunreiter, C. Daly, and P. R. Roehrdanz. 2011. The impact of climate change on California's ecosystem services. Climatic Change 109:465-484.

Shaw, M. R., E. S. Zavaleta, N. R. Chiarello, E. E. Cleland, H. A. Mooney, and C. B. Field. 2002. Grassland responses to global environmental changes suppressed by elevated $\mathrm{CO}_{2}$. Science 298: 1987-1990.

Silver, W. L., R. Ryals, and V. Eviner. 2010. Soil Carbon Pools in California's Annual Grassland Ecosystems. Rangeland Ecology \& Management 63:128-136. 
Slenning, B. D. 2010. Global Climate Change and Implications for Disease Emergence. Veterinary Pathology 47:28-33.

Smith, S. D., T. E. Huxman, S. F. Zitzer, T. N. Charlet, D. C. Housman, J. S. Coleman, L. K. Fenstermaker, J. R. Seemann, and R. S. Nowak. 2000. Elevated CO2 increases productivity and invasive species success in an arid ecosystem. Nature 408:79-82.

Spiegal, S., L. Huntsinger, P. Hopkinson, and J. Bartolome. 2016. Range Ecosystems. Pages 835-864 in H. A. Mooney and E. S. Zavaleta, editors. Ecosystems of California. University of California Press, Berkeley, California.

Stewart, I., A. A. Seawright, and G. R. Shaw. 2008. Cyanobacterial poisoning in livestock, wild mammals and birds-an overview. Pages 613-637 Cyanobacterial harmful algal blooms: state of the science and research needs. Springer.

Strain, B. R., and S. D. Smith. 1985. Reponse of Great Basin plants to atmospheric $\mathrm{CO}_{2}$ enrichment. American Journal of Botany 72.

Suttle, K. B., M. A. Thomsen, and M. E. Power. 2007. Species Interactions Reverse Grassland Responses to Changing Climate. Science 315:640-642.

Theoharides, K. A., and J. S. Dukes. 2007. Plant invasion across space and time: factors affecting nonindigenous species success during four stages of invasion. New Phytol 176:256-273.

Thorne, J. H., R. M. Boynton, L. E. Flint, and A. L. Flint. 2015. The magnitude and spatial patterns of historical and future hydrologic change in California's watersheds. Ecosphere 6:1-30.

United States Fish and Wildlife Service. Designation of Critical Habitat for the California RedLegged Frog, and Special Rule Exemption Associated With Final Listing for Existing Routine Ranching Activities; Final Rule. Federal Register 2006 Apr 13 71(71):1924419346.

Van Soest, P. J. 1982. Nutritional Ecology of the Ruminant. Cornell University Press, Ithaca, NY.

Walther, G.-R. 2003. Plants in a warmer world. Perspectives in Plant Ecology, Evolution and Systematics 6:169-185.

Westerling, A., and B. Bryant. 2006. Climate change and wildfire in and around California: fire modeling and loss modeling.

Westerling, A. L., B. P. Bryant, H. K. Preisler, T. P. Holmes, H. G. Hidalgo, T. Das, and S. R. Shrestha. 2011. Climate change and growth scenarios for California wildfire. Climatic Change 109:445-463.

$\mathrm{Xu}, \mathrm{L}$. , and D. D. Baldocchi. 2004. Seasonal variation in carbon dioxide exchange over a Mediterranean annual grassland in California. Agricultural and Forest Meteorology 123:79-96.

Zavaleta, E. S., M. R. Shaw, N. R. Chiariello, B. D. Thomas, E. E. Cleland, C. B. Field, and H. A. Mooney. 2003. Grassland responses to three years of elevated temperature, $\mathrm{CO}_{2}$, precipitation, and N deposition. Ecological Monographs 73:585-604. 


\title{
Chapter Four: Non-Climatic Factors Affecting Rangeland SUSTAINABILITY
}

\author{
Pelayo Alvarez and Amber Kerr
}

\begin{abstract}
SUMMARY
In Chapter 3, we explored current knowledge about how direct and indirect impacts of climate change - along with other biophysical factors - may affect the productivity and sustainability of rangelands in California. However, many of the biggest challenges to rangeland sustainability do not primarily arise from climate or biology, but rather from social, economic, and policy-related factors. Climate risks need to be examined in this broader context. In this chapter, we provide a brief overview of these socioeconomic drivers of change in California rangelands, acknowledging that a full examination is beyond the scope of this report.
\end{abstract}

\section{INTRODUCTION}

The productivity and viability of ranching operations in California is already challenged by complex socioeconomic factors operating at different scales. Climate change will exacerbate some of the existing challenges to rangelands, but may also create new opportunities. Climate change may also interact with non-climatic factors on rangelands in complex and unpredictable ways.

We propose the framework in Figure 4.1 as a way to think about how climate change relates to other factors affecting rangeland in California. Because this is a climate vulnerability assessment, the majority of this report focuses on the relationships highlighted in blue (Figure 4.1); however, this chapter aims to provide an overview of the non-climate factors and how they may interact with climatic factors.

Currently, the net effect of all these drivers on rangeland viability appears to be negative, as suggested by California's recent net loss of more than 20,000 rangeland acres annually (Cameron et al., 2014).We begin our

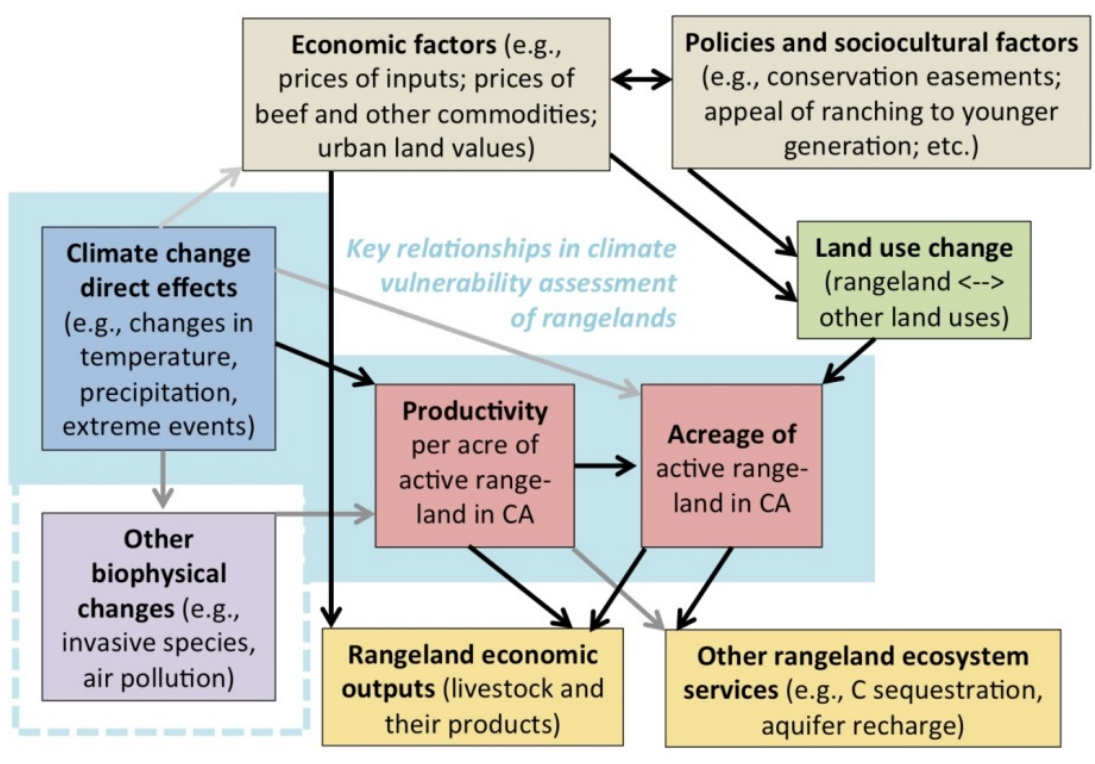

Figure 4.1: Conceptual map of climatic and non-climatic factors affecting rangeland productivity. The core focus areas of this report (direct climate impacts) are highlighted in blue, with the blue dashed line representing biophysical changes indirectly related to climate change. Darker arrows indicate potentially stronger relationships between two factors. Most relationships in this diagram can be modulated by rangeland management strategies (e.g., Torell et al. 2010). 
discussion with an examination of this trend toward rangeland loss.

\section{RANGELAND CONVERSION}

Rangelands in California are being converted to urban uses, including both residential and commercial development, and intensive agricultural uses, such as vineyards and orchards (Cameron et al. 2014). The California Department of Conservation Farmland Mapping and Monitoring Program (FMMP) conducts periodic evaluations of changes in land use on agricultural lands throughout California. The CAL FIRE Fire Resource and Assessment Program (FRAP) conducted an analysis of FMMP data from 1992-2010 to determine the amount of land converted from rangeland to urban development.

The results indicated that between 1992 and 2010, over 480,000 acres of potential grazing land were converted to urban development (averaging 27,000 acres/year-a similar estimate to Cameron et al., 2014). Nearly half of that conversion occurred in Southern California. The San Francisco Bay and San Joaquin Valley regions accounted for 27 percent of the change. About 8 percent of the change occurred in the Sierra Foothills region. The yearly change peaked from 2000-2006 and declined substantially during the recession of 2008-2010.

Cameron et al. (2014) determined that between 1984 and 2008, more than 484,000 acres were converted from rangeland in the California Rangeland Conservation Coalition focus area (covering 33 million acres including the Central Valley, Sierra Foothills and the inner Coast Ranges). About half the conversion was to development, with most of the remainder to intensive agriculture (Figure 4.2). Much of the conversion to cropland in this region was due to the proliferation of high-value specialty crops.

Some estimates of rangeland loss are even higher than this. In the 2015 National Resources Inventory from USDA-NRCS, California's acreage of active rangeland is estimated to have declined from 20,772,300 acres in 1982 to $18,891,300$ acres in 2012-a loss of almost 63,000 acres per year. This report estimates that cropland acres also declined slightly over the same time, so it would be overly simplistic to assume a zero-sum conversion from rangeland to cropland. 


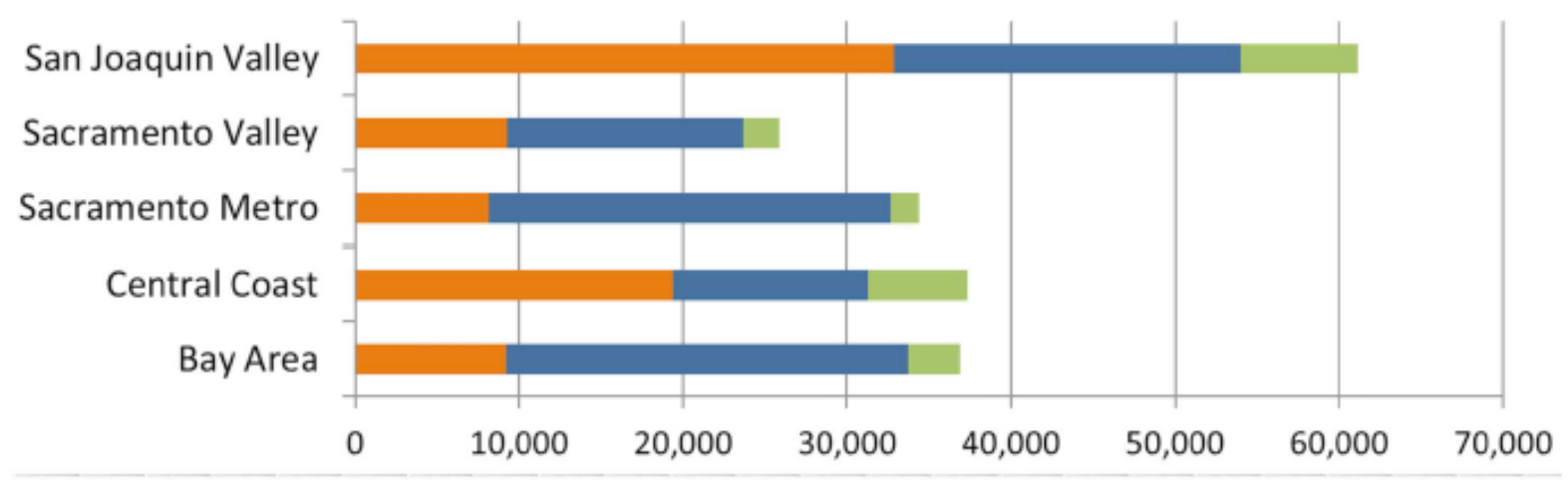

Hectares

agriculture Development $\quad$ Other

Figure 4.2: Conversion from rangeland to other land uses, 1984-2008 (Source: FRAP 2015 citing Cameron et al. (2014))

Conversion of rangelands to other uses has direct impacts on the ranching industry and alters the flow of ecosystem services from rangelands (Byrd et al. 2015). As ranches are converted, the infrastructure that supports ranching activities (e.g., veterinarians, equipment suppliers, processing facilities, and providers of technical assistance) is eroded. Rangeland conversion also changes the character of rural communities, as ranches are replaced by exurban residential development.

Impacts of rangeland loss go beyond direct effects on the livestock industry and include losses of habitat for wildlife, increased demands for water, and loss of open space, which are beyond the scope of this report.

\section{SOCIOECONOMIC FACTORS}

Annual income derived from grazing land is usually low compared to the value of using that land for urban development or intensive agriculture (approximately \$5,000-7,000 per acre per year for walnut and almond orchards respectively, versus $\$ 500$ for ranching). Low diversification (i.e., most ranches are devoted solely to beef cattle production) makes the ranching industry in California vulnerable to the fluctuations of beef cattle markets.

The ability to pass the ranch to the next generation is affected by the lack of incentives for the next generation to take up an activity that requires high effort and low returns. Prospective new ranchers must confront high land prices and increased competition for grazing leases. Figure 1.3 in Chapter 1 shows that the average age of ranch operators in California is almost 60 years old, with a quarter being 70 or older. Although the average age of ranchers has not increased in recent years, neither has it shown signs of decreasing. 
The public image of ranching in California is somewhat mixed, despite recent research demonstrating ranching's potential ecological benefits (Cameron et al. 2014; Byrd et al. 2015) and sociocultural importance (e.g., Huntsinger and Oviedo 2014). Public education campaigns (e.g., Barry et al. 2016) may in time garner more support for grazing on public lands, but some environmental organizations highlight negative consequences of grazing and campaign against it (e.g., CBD, 2002; Glaser et al., 2015). Public perception can ultimately affect land use policies and funding, thus becoming a major factor (and a major unknown) in determining the sustainability of ranching in California.

\section{Policy}

Budget cuts and shifting priorities have reduced the availability of technical assistance to ranchers in recent years. Funding for land conservation programs implemented at the state level, such as the Williamson Act, can contribute to the viability of ranching operations (Wetzel et al. 2012).

The regulatory environment can also be challenging for California ranchers. Often the lack of coordination among federal, state, and local regulations designed to protect natural resources (such as water quality and endangered species) can impose additional time and labor costs to ranching operators interested in enhancing their properties. An example is the restoration of stock ponds, essential to providing water for livestock and habitat for wildlife species. Restoring a stock pond may require permits from multiple agencies with potentially conflicting policies and procedures.

Land use changes will continue throughout the state, with the Central Valley a location of particular interest (Figure 4.3). More than half of the Central Valley is predicted to shift to a different land use by 2051 (CAL FIRE FRAP 2010, Radeloff et al. 2012). In the future, water availability may be a main factor contributing to the conversion of rangelands to croplands. Regulation of groundwater might slow down that type of conversion, and water limitations (for example, due to more severe droughts) could in fact reverse the trend and catalyze conversion of croplands back into rangelands (Sleeter 2008, Sleeter et al. 2011, Soulard and Wilson 2015).

Byrd et al. (2015) studied the combined effects of climate change on ecosystem services from rangelands in California - specifically, water yield, carbon sequestration, and habitat. Comparing three different IPCC scenarios and two GCM models, the authors showed that the impacts of climate change and land use change may interact in important ways. For example, the effects of urban development on increasing impervious surfaces combined with periods of drought reduces the opportunity for groundwater recharge.

All these drivers may cause profound changes in the structure of the ranching industry in California. Particularly, they may result in the consolidation of ranching operations into fewer, larger operations. Rangelands of lower or marginal productivity are especially vulnerable. 
Negative impacts of climate change (e.g., increased uncertainty of forage productivity, shifts in plant community composition) may further discourage smaller ranchers who are already on the brink of abandoning the activity for economic or social reasons (e.g., not all members of the family want to keep ranching). Larger operations may be more resilient to those impacts in the first place, and may also have the financial resources to acquire smaller ranches that come up for sale. They may also be more competitive when applying for grazing leases. However, roughly 80 percent of operations have some form of off-ranch income (Roche et al. 2015), which may help buffer the negative effects of economic uncertainty.

It is difficult to accurately predict the direct effects of climate change on rangelands because of the complexity of atmosphere-biosphere interactions and the uncertainty in emissions trajectories (see Chapter 2). Attempting to model the economic, social, and cultural factors mentioned in this chapter would make quantitative predictions even more difficult. Instead, we provide a qualitative summary (Table 4.1) of how these factors (and their interactions) may affect California rangelands in the future. In some cases, it may be premature to even predict the $(+)$ or (-) sign of the effect.

Table 4.1. Summary of climate- and non-climate-related trends that may positively (+) or negatively (-) affect rangeland acreage and productivity in California. Trends thought to be most important are in bold.

\begin{tabular}{|c|c|c|}
\hline & Possible positive effects $(+)$ & Possible negative effects (-) \\
\hline \multicolumn{3}{|l|}{ Climate-related trends } \\
\hline $\begin{array}{l}\text { Changes in plant } \\
\text { community composition }\end{array}$ & $\begin{array}{l}\text { Grasslands may increase in } \\
\text { extent, moving upslope and } \\
\text { replacing shrublands and } \\
\text { woodlands }\end{array}$ & $\begin{array}{l}\text { Woodland trees may diminish; } \\
\text { arid grassland may become } \\
\text { desert; desert shrub may become } \\
\text { barren }\end{array}$ \\
\hline $\begin{array}{l}\text { Changes in forage } \\
\text { productivity }\end{array}$ & $\begin{array}{l}\text { In Northern CA and Coast } \\
\text { Range, productivity could } \\
\text { increase due to mild winters } \\
\text { with higher average rain }\end{array}$ & $\begin{array}{l}\text { Many or most rangelands in } \\
\text { CA could lose productivity due } \\
\text { to heat stress and water deficit }\end{array}$ \\
\hline $\begin{array}{l}\text { Changes in invasive } \\
\text { species }\end{array}$ & $\begin{array}{l}\text { Invasive warm-season grasses } \\
\text { could be outcompeted due to } \\
\mathrm{CO}_{2} \text { fertilization effect }\end{array}$ & $\begin{array}{l}\text { Heat- and drought-tolerant } \\
\text { invasives could spread more } \\
\text { rapidly }\end{array}$ \\
\hline Changes in fire regimes & $\begin{array}{l}\text { Livestock grazing could } \\
\text { become more in demand as a } \\
\text { solution to reduce fuel loads in } \\
\text { wildlands and rural areas }\end{array}$ & $\begin{array}{l}\text { Increased frequency and intensity } \\
\text { of fires could damage rangeland } \\
\text { soil, reduce productivity, and } \\
\text { change dominant species }\end{array}$ \\
\hline $\begin{array}{l}\text { Increased awareness of } \\
\text { climate impacts }\end{array}$ & $\begin{array}{l}\text { Carbon markets may } \\
\text { incentivize rangeland } \\
\text { conservation \& management }\end{array}$ & $\begin{array}{l}\text { Consumers may shift preferences } \\
\text { away from beef and lamb due to } \\
\text { climate footprint concerns }\end{array}$ \\
\hline
\end{tabular}




\begin{tabular}{|l|l|l|}
\hline $\begin{array}{l}\text { Economic pressures for } \\
\text { land use conversion }\end{array}$ & $\begin{array}{l}\text { Some cropland may be } \\
\text { converted to rangeland if water } \\
\text { supplies are too limited }\end{array}$ & $\begin{array}{l}\text { Rangeland may be rapidly lost } \\
\text { to lucrative housing } \\
\text { developments and permanent } \\
\text { crops }\end{array}$ \\
\hline $\begin{array}{l}\text { Long-term national and } \\
\text { global forces in } \\
\text { livestock markets }\end{array}$ & $\begin{array}{l}\text { There is potential for increased } \\
\text { exports to Asia, including } \\
\text { China }\end{array}$ & $\begin{array}{l}\text { Prices are unpredictable and may } \\
\text { decline; US per capita } \\
\text { consumption of red meat is flat or } \\
\text { declining }\end{array}$ \\
\hline $\begin{array}{l}\text { Transfer of ranch assets } \\
\text { to the next generation }\end{array}$ & $\begin{array}{l}\text { Young ranchers may innovate } \\
\text { with income diversification }\end{array}$ & $\begin{array}{l}\text { Social and economic incentives } \\
\text { of ranching may not attract young } \\
\text { people }\end{array}$ \\
\hline $\begin{array}{l}\text { Increased public } \\
\text { environmental } \\
\text { awareness }\end{array}$ & $\begin{array}{l}\text { Rangelands may be } \\
\text { increasingly valued for their } \\
\text { provision of ecosystem } \\
\text { services and open space }\end{array}$ & $\begin{array}{l}\text { Ranchers may be criticized for } \\
\text { soil erosion, riparian damage, and } \\
\text { greenhouse gas emissions }\end{array}$ \\
\hline $\begin{array}{l}\text { Alliances between } \\
\text { ranchers, NGOs, and } \\
\text { governments }\end{array}$ & $\begin{array}{l}\text { Goals of conservationists and } \\
\text { producers can be aligned; } \\
\text { limited funds can be leveraged }\end{array}$ & $\begin{array}{l}\text { Ranchers may have less } \\
\text { autonomy; ranching culture may } \\
\text { change }\end{array}$ \\
\hline
\end{tabular}

EXAMPLES OF KEY INTERACTIONS BETWEEN CLIMATE AND NON-CLIMATE FACTORS

- Policies to promote soil carbon storage and other ecosystem services $(+)$ may help counteract economically-driven trends of rangeland conversion (-).

- Harm to rangelands from drought, fire, and/or invasive species (-) may exacerbate economic pressures and hasten land use conversion (-).

- Heat and drought from climate change may cause grassland forage to become less available at lower elevations (-) and proportionally more available at higher elevations, such as in national forests, but ranchers' ability to adapt may be constrained by limitations on stocking cattle on public lands (-).

- Increasing limitations on water supply for crops (due to climate change-induced heat and drought) may favor preservation of rangelands, or even net conversion to rangelands $(+)$.

Because of the potential for climate change to add to the already significant challenges to rangeland sustainability, and conversely because of the potential for well-managed rangeland to contribute to regional climate mitigation and adaptation, rangeland preservation for multiple ecosystem services may need to become a higher priority for local and state government agencies in the coming decades. 


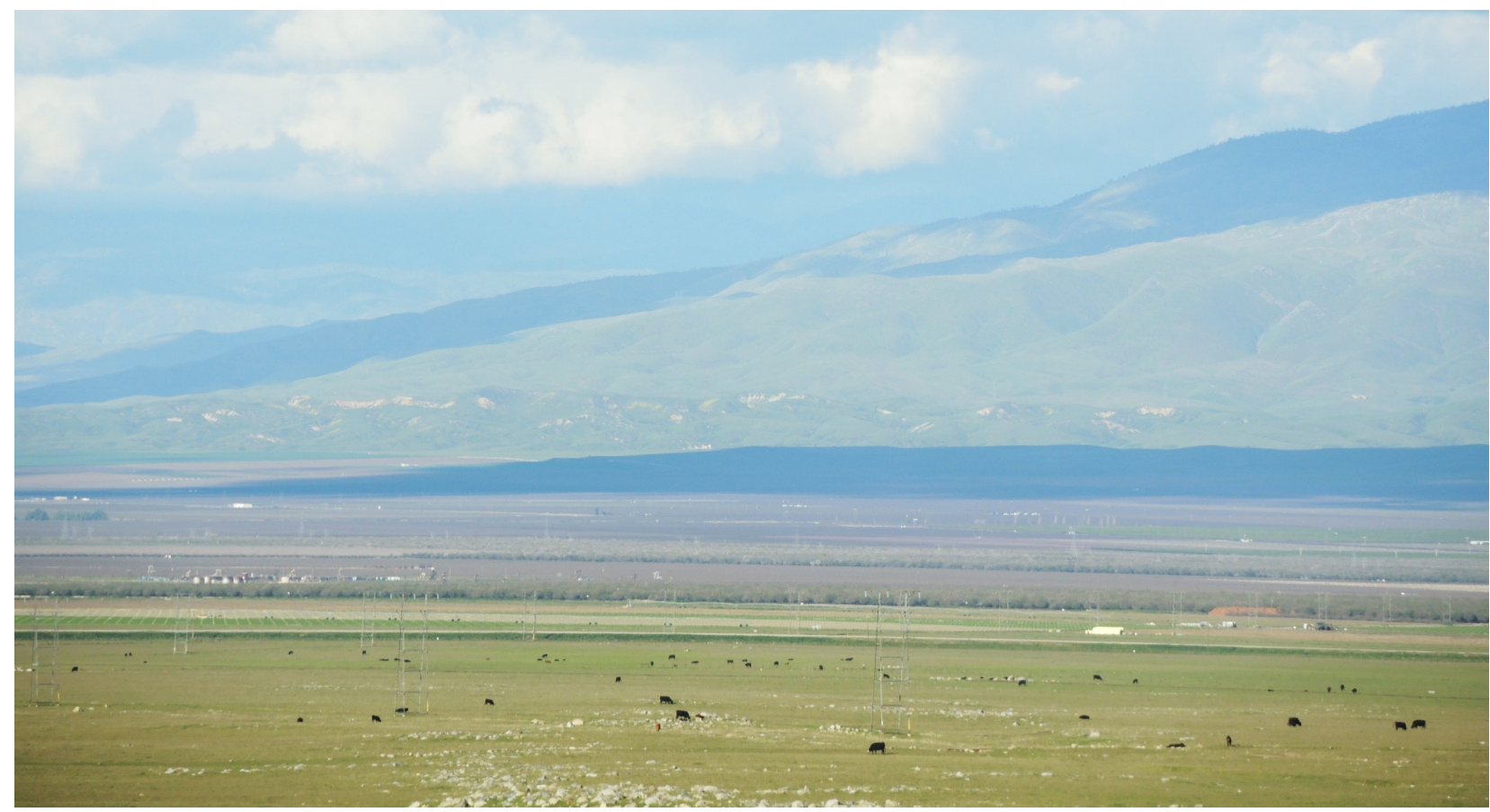

Figure 4.3. The southern San Joaquin Valley is expected to face increasing water stress in the future, which may affect relative profitability of different land use options. Here, cattle graze on land surrounded by vineyards, citrus groves, and almond orchards. (Kern County, CA, March 2017. Photo: Amber Kerr.)

\section{REFERENCES}

Barry, S., S. Larson, and L. Bush (2016). Understanding working rangelands: a year in the life of a beef cow. University of California Agriculture and Natural Resources. UC ANR Publication 8526. http://anrcatalog.ucanr.edu/pdf/8526.pdf

Byrd, K. B., L. E. Flint, P. Alvarez, C. F. Casey, B. M. Sleeter, C. E. Soulard, A. L. Flint, and T. L. Sohl. 2015. Integrated climate and land use change scenarios for California rangeland ecosystem services: Wildlife habitat, soil carbon, and water supply. Landscape Ecology 30:729-750.

California Department of Forestry and Fire Protection Fire and Resource Assessment Program. 2010. California's Forests and Rangelands: 2010 Assessment. California Department of Forestry and Fire Protection, Sacramento, CA.

Cameron, D. R., J. Marty, and R. F. Holland. 2014. Whither the rangeland?: Protection and conversion in California's rangeland ecosystems. PLoS One 9:e103468.

Center for Biological Diversity (2002). "Cattle grazing and the loss of biodiversity in the East Bay" (14 pp). Accessed February 12, 2018. http://www.biologicaldiversity.org/publications/papers/GRAZING-JM.PDF. 
Glaser, C., C. Romaniello, C. and K. Moskowitz (2015). "Costs and Consequences: The Real Price of Livestock Grazing on America's Public Lands.” Center for Biological Diversity. http://www.biologicaldiversity.org/programs/public_lands/grazing/pdfs/CostsAndConseq uences_01-2015.pdf

Huntsinger L, Oviedo JL (2014) Ecosystem Services are Social-Ecological Services in a Traditional Pastoral System: the Case of California's Mediterranean Rangelands. Ecology and Society 19.

Radeloff, V. C., E. Nelson, A. J. Plantinga, D. J. Lewis, D. Helmers, J. J. Lawler, J. C. Withey, F. Beaudry, S. Martinuzzi, V. Butsic, E. Lonsdorf, D. White, and S. Polasky. 2012. Economic-based projections of future land use in the conterminous United States under alternative policy scenarios. Ecological Applications 22:1036-1049.

Roche, L. M., T. K. Schohr, J. D. Derner, M. N. Lubell, B. B. Cutts, E. Kachergis, V. T. Eviner, and K. W. Tate. 2015. Sustaining working rangelands: Insights from rancher decision making. Rangeland Ecology \& Management 68:383-389.

Sleeter, B. M. 2008. Late 20th century land change in the Central California Valley Ecoregion. The California Georapher 48:27-59.

Sleeter, B. M., T. S. Wilson, C. E. Soulard, and J. Liu. 2011. Estimation of late twentieth century land-cover change in California. Environmental Monitoring and Assessment 173:251266.

Soulard, C. E., and T. S. Wilson. 2015. Recent land-use/land-cover change in the Central California Valley. Journal of Land Use Science 10:59-80.

Torell, L. A., S. Murugan, and O. A. Ramirez. 2010. Economics of flexible versus conservative stocking strategies to manage climate variability risk. Rangeland Ecology \& Management 63:415-425.

U.S. Department of Agriculture. 2015. Summary Report: 2012 National Resources Inventory, Natural Resources Conservation Service, Washington, DC, and Center for Survey Statistics and Methodology, Iowa State University, Ames, Iowa. http://www.nrcs.usda.gov/technical/nri/12summary

Wetzel, W. C., I. L. Lacher, D. S. Swezey, S. E. Moffitt, and D. T. Manning. 2012. Analysis reveals potential rangeland impacts if Williamson Act eliminated. California Agriculture 66:131-136. 


\title{
Chapter Five: Adaptation Options for RAngeland MAnagers
}

\author{
Julian Reyes, Joel Brown, and Leslie Roche
}

\begin{abstract}
SUMMARY
California rangelands offer many valuable ecosystem services such as forage production, habitat for diverse wildlife, and cultural and recreational opportunities. The practices managers choose to implement determine the condition of rangeland and the mix of services that are provided to public and private markets. We begin by showing grazing and livestock management in anticipation of forage supply and demand is the key to climate-adaptive rangeland management. We then describe strategies available to ranchers when adapting to climate and weather variability, including some of the challenges and opportunities for adaptation. We conclude by distinguishing between proactive and reactive adaptive responses.
\end{abstract}

\section{Grazing Management as the Key to Rangeland Management and AdAPtation}

Any discussion of rangeland management in California must begin with livestock grazing management, regardless of assumptions about climate change (Chaplin-Kramer and George 2013, Macon et al. 2016). Further, any discussion of livestock grazing management must begin with adjusting the forage supply and forage demand balance. When supply exceeds demand, there are positive opportunities to allocate excess plant growth to other resource concerns (e.g., erosion control, wildlife habitat, prescribed burning), or there may be opportunity costs (e.g., missed revenue). When demand exceeds supply, resource degradation and diminished animal performance are predictable outcomes. Given that the supply of forage in a season is almost entirely a function of current season rainfall, managers have to constantly be prepared to adjust livestock numbers to match demand to supply.

Although proximity to large population centers and emerging markets offer opportunities to California rangeland managers to broaden the demand for both livestock and non-livestock ecosystem services, the majority of the discussion in this chapter will focus on different facets of livestock management as adaptation options. Moreover, the near-term economic and social reality is that grazing will likely remain the dominant land use and economic output along with those services provided by rangelands in the foreseeable future (Chaplin-Kramer and George 2013).

\section{Challenges and Opportunities for Adaptation}

Ranchers in California have historically been able to adapt to variable climatic conditions and economic uncertainty. Climate change, though, is projected to increase the frequency and magnitude of extreme weather events beyond those typical fluctuations previously experienced. Adapting to these changes will require novel strategies to ensure the viability of ranching in the future (Briske et al. 2015). Several adaptation strategies at different operational scales will be 
required to minimize climate change impacts and to take advantage of certain economic opportunities brought about by new environmental conditions (Henry et al. 2012, Joyce et al. 2013, Pitesky et al. 2014, Briske et al. 2015, Weindl et al. 2015).

Although climate change is generally forecast in terms of change over multiple decades, it is the short-term manifestation of climate change and variability that managers have to confront and adapt to most urgently (Brown et al. 2016). Implementing strategies, tactics, and practices to respond to climate change is thus not only a matter of selecting appropriate responses, but also of identifying and acting upon well-defined 'trigger' points. In other words, successful adaptation is a matter of both knowing when to act and knowing what to do.

Ranchers in California have benefited from a long history of research and development of products that define the relationships among temperature, rainfall, and forage production (Murphy 1970, George et al. 1988, Bartolome et al. 2009). Based on field observations and empirical modeling, these relationships provide predictions of sufficient accuracy to make stocking rate decisions. The primary shortcoming of these models is not a lack of data on statistical relationships between climatic conditions and forage production, but rather the fact that models do not represent underlying biophysical processes in detail, making accurate large-scale and long-term predictions difficult.

Even with the difficulties of developing predictive models at the landscape scale, forage-climate relationships still have value for individual ranchers as both are bases for scenarios (probabilities) and for contingency planning. Thus, they are valuable mid- and long-term planning tools that can greatly aid in short-term decision-making. Despite this, on-going research has improved processbased models to incorporate site-specific characteristics of California grasslands, as well as integrate sophisticated predictions of California's future climate (Lenihan et al. 2003)

A recent survey of ranchers in California suggests that ranchers are already aware of changes in the climate (Roche 2016). Ranchers and land managers will need to develop alternative management skills and have flexibility to cope with climate extremes. Emotional and financial flexibility are key components in the adaptive capacity of ranchers. Limited ability or willingness to change management strategies in the face of climate change will increase ranchers' vulnerability. Ranchers with higher incomes and with large operations may be more likely to adopt management strategies to adapt to climate change (Kachergis et al. 2013, Briske et al. 2015).

\section{Specific Adaptation Strategies}

Management adaptation strategies specific to rangeland livestock production have been summarized in recent literature (Joyce et al. 2013). Strategies include adjusting stocking rates, development of drought management plans, changes in the class or breed of livestock, better management of invasive plants and animal parasites, changes in the structure of operations, and a geographic re-distribution of livestock operations (Joyce et al. 2013, Briske et al. 2015). Macon 
et al. (2016) identified responses, strategies, and tactics commonly deployed as practices to prepare for drought (proactive) and respond to drought (reactive). Given the predictions that rainfall is likely to be more erratic as a result of climate change (Chapter 3 ), these practices represent the most likely set of options to develop climate change adaptation strategies. We have broadened the Macon et al. discussion of drought response to consider other aspects of climate change adaptation.

\begin{tabular}{|l|l|l|}
\hline \multicolumn{2}{|l|}{ Table 5.1: Strategies for drought impact management based on the 2011 California Rangeland Decision- } \\
Making Survey (adapted from Macon et al. 2016). & $\%(\mathrm{n}=443)$ \\
\hline & Strategies to manage for drought impact & 34 \\
\hline Proactive (Preparing for drought) & Stock conservatively & 23 \\
& Rest pastures & 21 \\
& Incorporate yearling cattle & 12 \\
& Grassbank/stockpile forage & 11 \\
& Use weather predictions to adjust stock rate & 3 \\
& Add other livestock types for flexibility & 70 \\
& Reduce herd size & 69 \\
& Purchase feed & 39 \\
& Apply for government assistance programs & 39 \\
& Wean calves early & 26 \\
& Rent additional pastures & 24 \\
& Move livestock to another location & 23 \\
& Earn additional off-ranch income & 22 \\
& Sell retained yearlings & 8 \\
& Place livestock in a feedlot & 7 \\
& Maintain herd size; allow condition declines & 4 \\
\hline
\end{tabular}

\section{PROACTIVE RESPONSES}

Proactive responses are those that are developed and implemented prior to experiencing a climate stressor, such as drought. Macon et al. (2016) found that the majority of California ranchers surveyed in 2011 were already implementing forward-looking management practices for future drought events and its impacts. Of the 443 ranchers surveyed during this time period, $64 \%$ stated they were already "preparing" for drought and possibly looking at proactive practices (Table 5.1) to mitigate the short-term impacts. With this information, we provide detailed onproperty responses related to the proactive practices (Table 5.2) in line with adaptation options available under a changing climate (Joyce et al. 2013). A majority of these proactive responses corroborate the "planned" strategy "when adaptation responses are developed and implemented before climate-induced changes are observed" (Joyce et al. 2013).

\section{REACTIVE RESPONSES}

Less desirable, but certainly necessary, are "reactive" tactics and practices deployed to respond in the short-term to events resulting from a changing climate. Although the most likely shortterm manifestation of climate change in California rangelands is drought (see Chapters 2 and 3 ), it is likely that other temperature- and precipitation-related events (heat waves; cold snaps; more intense storms, bigger floods) will be encountered by land managers. Reactive responses are, by 
definition, approaches that can lessen the effects of experienced climate change events, and should be considered a part of a contingency plan. More details on reactive responses can be found in Table 5.2.

In contrast to proactive strategies that are implemented or planned prior to impact, options in two other categories of adaptation options ("no regrets" and anticipatory) can be used to reactively respond to changes in climate (Joyce et al. 2013). No-regrets management strategies can typically be implemented without a justification because they can provide benefits notwithstanding changes in climate or events such as drought. Examples include invasive species monitoring and control, conservation stocking, and using smaller animals (Joyce et al. 2013). By contrast, anticipatory strategies are event- or trigger-dependent adaptation options. Essentially, there is an acknowledgement of climate change impacts, but the actual implementation of a planned adaptation option will only occur after climate-induced events have occurred (Joyce et al. 2013).

\section{BOTTOM LINE}

To successfully adapt to climate change in California rangelands, the core short-term strategy is adjusting livestock numbers in response to the departure of the current year's precipitation from the long-term average. Decisions on various time-scales — monthly, yearly, decadal — regarding when to act and what action to take do not have to be entirely ad-hoc. Historical records and prediction models are valuable in determining both the range of possibilities and the probabilities of forage conditions in the months immediately prior to the commencement of the annual grazing cycle. It is important to develop a range of contingencies for both reactive and proactive decision-making to effectively counter short-term, acute events and long-term, prolonged resource-limiting conditions like drought. By supporting robust analytical tools that incorporate social, ecological, and environmental conditions, implementation of the aforementioned contingencies and coping strategies can be effective and match established on-the-ground objectives. 


\begin{tabular}{|c|c|}
\hline Category & Detailed on-property preparation description \\
\hline \multicolumn{2}{|c|}{ Proactive responses } \\
\hline Infrastructure & $\begin{array}{l}\text { Individual ranchers can cope with potential changes in climate by } \\
\text { building infrastructure to improve ease of livestock management and } \\
\text { ensure access to water. Other types of infrastructure can also aid in } \\
\text { pasture rest and grass banking practices. }\end{array}$ \\
\hline Stocking rate & $\begin{array}{l}\text { Conservative stocking rates for California rangelands vary widely and } \\
\text { primarily reflect long-term precipitation. Stocking rate information } \\
\text { and calculators are widely available from NRCS, UCCE, and private } \\
\text { consultants. Annual rangeland management for livestock grazing has } \\
\text { historically been based on stocking rate adjustments to meet livestock } \\
\text { performance and residual dry matter (RDM) goals. Recommended } \\
\text { RDM levels for California rangelands are available from similar } \\
\text { sources. In addition, planned grazing using multiple paddocks can } \\
\text { improve livestock distribution and increase options for forage } \\
\text { management. }\end{array}$ \\
\hline $\begin{array}{l}\text { Flexible livestock } \\
\text { composition }\end{array}$ & $\begin{array}{l}\text { One key to flexibly managing stocking rates is the ability to make } \\
\text { relatively short-term adjustments. Short-term flexibility can be } \\
\text { supported by incorporating a diversity of species (cattle, sheep, goats) } \\
\text { and classes (stockers, cows) of grazing animals into operations. }\end{array}$ \\
\hline $\begin{array}{l}\text { Herd } \\
\text { management }\end{array}$ & $\begin{array}{l}\text { Implementing existing best practices in herd management can both } \\
\text { increase flexibility in drought response and minimize risk. These } \\
\text { techniques (increasing conception rates, increasing weaning weights, } \\
\text { shortening calving season) are described in livestock management } \\
\text { guides }^{2} \text { and have specific applications for California. }\end{array}$ \\
\hline $\begin{array}{l}\text { Vegetation } \\
\text { management }\end{array}$ & $\begin{array}{l}\text { Weed control can ensure that forage is available and accessible, and } \\
\text { can reduce the abundance of species that are unpalatable or harmful to } \\
\text { livestock (e.g., yellow starthistle). Weed management may require } \\
\text { long-term planning, including education on new or best available } \\
\text { control techniques. Successful weed control may also require } \\
\text { consideration of landscape-scale context, as weed prevalence can } \\
\text { depend on control efforts undertaken on neighboring properties. }\end{array}$ \\
\hline Genetics & $\begin{array}{l}\text { Introducing more climate change tolerant genetics in either livestock } \\
\text { or forage plants poses a difficult challenge. Challenges and barriers to } \\
\text { adopting this practice include identifying what traits are more likely to } \\
\text { be successful, establishing those traits in breeding stock or } \\
\text { germplasm, and effectively managing either forage or livestock. }\end{array}$ \\
\hline $\begin{array}{l}\text { Economic } \\
\text { diversification }\end{array}$ & $\begin{array}{l}\text { Diversification is an important strategy for mitigating the economic } \\
\text { impacts of climate change on ranching operations. Diversified ranch } \\
\text { uses, including agro-tourism, hunting, and working ranch stays, can } \\
\text { generate additional income. However, diversifying on-ranch income is } \\
\text { a strategic proactive decision that may require substantial investment }\end{array}$ \\
\hline
\end{tabular}

\footnotetext{
${ }^{2}$ Management guides can be obtained from the University of California Cooperative Extension Livestock and Range (UCCELR) program: http://ucanr.edu/sites/UCCE_LR/Rangeland_-_Pasture/
} 


\begin{tabular}{|c|c|}
\hline & and tolerance of risk. \\
\hline \multicolumn{2}{|l|}{ Reactive responses } \\
\hline $\begin{array}{l}\text { Herd/ } \\
\text { vegetation } \\
\text { management }\end{array}$ & $\begin{array}{l}\text { Reducing or increasing herd size is a frequent response to changing } \\
\text { weather events. The balance between animal performance and } \\
\text { resource (i.e., vegetation) productivity must be considered together } \\
\text { since both can be degraded by inappropriate management, especially } \\
\text { during drought. }\end{array}$ \\
\hline $\begin{array}{l}\text { Forage } \\
\text { supplementation }\end{array}$ & $\begin{array}{l}\text { Responses to intra- and inter-annual changes in forage production due } \\
\text { to weather extremes or longer-term climate trends typically involve } \\
\text { adjustment of livestock numbers and buying or selling forage. } \\
\text { Responding to short-term drought conditions typically involves low- } \\
\text { quality forage. Purchasing feed is a viable response to short-term } \\
\text { drought conditions but can jeopardize ranch finances, especially in the } \\
\text { very near-term. A contingency plan to purchase feed should include a } \\
\text { clearly stated goal or goals (maintain animal performance, avoid } \\
\text { resource degradation, preserve herd genetics) as well as the } \\
\text { mechanisms for deploying the actions. In periods of unexpectedly } \\
\text { high forage production, harvesting forage for off-site sale or on-site } \\
\text { storage is possible, but exact locations and harvest/storage techniques } \\
\text { should be planned well in advance. Stockpiling forage for use in } \\
\text { drought requires careful planning of livestock distribution. }\end{array}$ \\
\hline
\end{tabular}




\section{REFERENCES}

Bartolome, J. W., R. D. Jackson, and B. Allen-Diaz. 2009. Developing data-driven descriptive models for Californian grasslands. Pages 124-135 in R. J. Hobbs and K. Suding, editors. New Models for Ecosystem Dynamics and Restoration.

Briske, D. D., L. A. Joyce, H. W. Polley, J. R. Brown, K. Wolter, J. A. Morgan, B. A. McCarl, and D. W. Bailey. 2015. Climate-change adaptation on rangelands: linking regional exposure with diverse adaptive capacity. Frontiers in Ecology and the Environment 13:249-256.

Brown, J. R., D. Kluck, C. McNutt, and M. Hayes. 2016. Assessing drought vulnerability using a socioecological framework. Rangelands 38:162-168.

Chaplin-Kramer, R., and M. R. George. 2013. Effects of climate change on range forage production in the San Francisco Bay Area. PLoS One 8:e57723.

George, M. R., C. A. Raguse, W. J. Clawson, C. B. Wilson, R. L. Willoughby, N. K. McDougald, D. A. Duncan, and A. H. Murphy. 1988. Correlation of Degree-Days with Annual Herbage Yields and Livestock Gains. Journal of Range Management 41:193-197.

Henry, B., E. Charmley, R. Eckard, J. B. Gaughan, and R. Hegarty. 2012. Livestock production in a changing climate: adaptation and mitigation research in Australia. Crop and Pasture Science 63:191-202.

Joyce, L. A., D. D. Briske, J. R. Brown, H. W. Polley, B. A. McCarl, and D. W. Bailey. 2013. Climate change and North American rangelands: assessment of mitigation and adaptation strategies. Rangeland Ecology and Management 66:512-528.

Kachergis, E., J. Derner, L. Roche, K. Tate, M. Lubell, R. Mealor, and J. Magagna. 2013. Characterizing Wyoming Ranching Operations: Natural Resource Goals, Management Practices and Information Sources. Natural Resources 04:45-54.

Lenihan, J. M., D. Raymond, D. Bachelet, and R. P. Neilson. 2003. Climate Change Effects on Vegetation Distribution, Carbon, and Fire in California. Ecological Applications 13:1667-1681.

Macon, D. K., S. Barry, T. Becchetti, J. S. Davy, M. P. Doran, J. A. Finzel, H. George, J. M. Harper, L. Huntsinger, and R. S. Ingram. 2016. Coping With Drought on California Rangelands. Rangelands 38:222-228.

Murphy, A. H. 1970. Predicted Forage Yield Based on Fall Precipitation in California Annual Grasslands. Journal of Range Management 23:363-365.

Pitesky, M., A. Gunasekara, C. Cook, and F. Mitloehner. 2014. Adaptation of Agricultural and Food Systems to a Changing Climate and Increasing Urbanization. Current Sustainable/Renewable Energy Reports 1:43-50.

Roche, L. 2016. Adaptive rangeland decision-making and coping with drought. Sustainability 8:1334.

Weindl, I., H. Lotze-Campen, A. Popp, C. Müller, P. Havlík, M. Herrero, C. Schmitz, and S. Rolinski. 2015. Livestock in a changing climate: production system transitions as an adaptation strategy for agriculture. Environmental Research Letters 10:094021. 


\title{
Chapter Six: Conclusions ANd Future Research NeEdS
}

\author{
Pelayo Alvarez and Amber Kerr
}

In this chapter, we propose six overarching questions for short- and long-term research on California rangelands under future climate. Much work has already been done in this field, both specific to California and at a larger scale (as reviewed in Chapter 3). Existing literature suggests that climate change will overall have more negative than positive impacts on California rangelands, but there are many caveats arising from spatial heterogeneity, uncertainties in climate model output, complexities of species interactions, and unknown economic factors.

Our general recommendation is that future research, to the extent possible, be conducted at time and spatial scales that are appropriate to rancher decision-making. Typically, ranchers make management decisions on hundreds or thousands of acres and time scales of months or years, while climate change research is usually conducted for broader geographic areas and on much longer time scales. Here, range science can draw upon the emerging field of climate data usability (Lemos et al. 2012, Jones et al. 2016).

We urge scientists, funders, policymakers, and ranchers to consider the following questions as they prepare for future climatic conditions on California rangelands:

\section{How will climate change directly and indirectly impact rangeland vegetation and hydrology in California? What adaptation options are available?}

\section{What we know:}

We hope that our spatially detailed projection of changes in climatic water deficit (Chapter 2) will help guide future research efforts on highly exposed and highly important rangelands in California. However, more work is needed using alternate assumptions, datasets, and models. Furthermore, it is important (though difficult) to go a step further and translate changes in climatic variables to changes in forage production and species composition in California. Some authors have already done so at smaller (Chaplin-Kramer and George 2013) or larger spatial scales (Reeves and Bagne 2016).

\section{What we don't know:}

Further research is needed on the responses of individual plant species and genotypes, as well as key functional groups (e.g., native perennials, exotic annuals), to the direct effects of climate change, including elevated $\mathrm{CO}_{2}$, increasing temperature, and water deficit. Studies should be undertaken to identify desirable rangeland taxa that may be best adapted to future conditions, as well as how

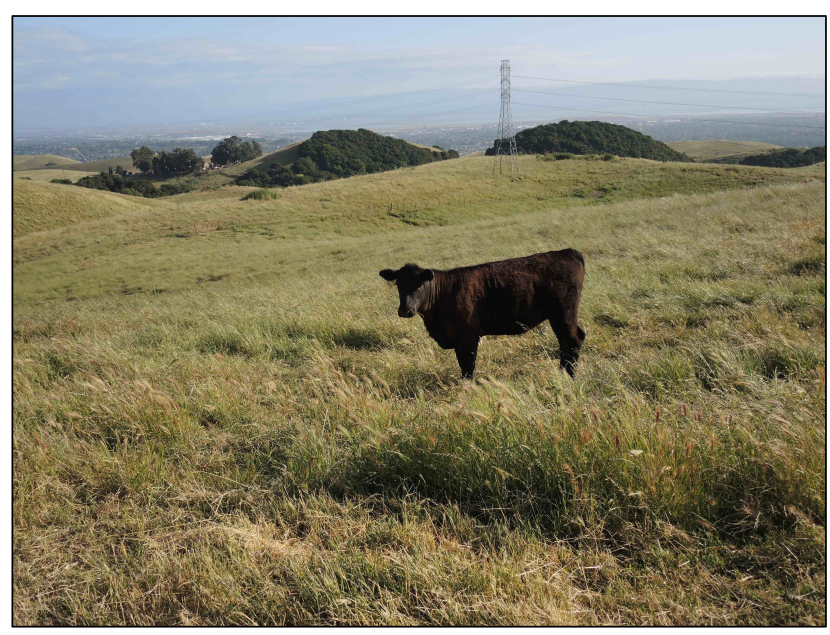

Grazing at Vargas Plateau Regional Park, Fremont, CA, 66 May 2017. (Photo by Amber Kerr.) 
climate change will influence the range and impacts of existing and arriving exotic species (Clements and Di tommaso 2011).

Additional research is also needed to address how climate change may affect interactions within grassland vegetation communities (Suttle et al. 2007). Areas of concern include interactions among plants (including individuals, species, and functional groups), between plants and their pollinators, and between plants, herbivores, and pathogens. Competitive dynamics between native and invasive plants are particularly important in California rangelands (Robison 2009). Under future climate scenarios, novel combinations of native and non-native species may be needed to achieve restoration goals (Gornish et al. 2016).

In addition, the effectiveness of best management practices to increase water capture and water quality on rangelands will become even more important in the face of climate change. Stock ponds are crucial to rangeland viability and ecosystem services (Huntsinger and Oviedo 2014). Developing hydrological models for stock ponds can help prioritize restoration efforts and conservation actions to improve ranchers' capacity to store water and continue providing essential habitat for wildlife. Research to develop new techniques to store water on rangelands will also be needed.

\section{2) What are the projected impacts of climate change on animal health and performance in California?}

\section{What we know:}

Studies have been published on the effects of climate change on animal health and performance at international scales (Nardone et al. 2010) and national scales (Reeves and Bagne 2016), but much key data is highly uncertain - for example, changes in forage quality, pests and disease, and surface water availability. Most research on climate and cattle health focuses on the dairy industry, where high-density confinement makes the animals more vulnerable to heat-related stresses and more dependent on human attention and intervention. The modest amount of research related to climate and health of beef cattle tends to focus on feedlots, for the same reason (Stull et al. 2007).

\section{What we don't know:}

In the short-term, a review of existing livestock breeds and/or traits that could increase the adaptability of livestock in California to adapt to climate change would help develop breeding programs focused on adaptation. This solution has already been proposed more generally for the U.S. as a whole (Scasta et al. 2016) and for the Southwest in particular (Havstad et al. 2016). More long-term experimental studies will be needed to evaluate those breeds that are better adapted to more arid systems and are heat and disease tolerant. More research is also needed on the benefits of shade trees in pastures (Sharrow 2000). Finally, the economic and practical feasibility of transitioning to new cattle breeds, and of trading off cattle with other livestock (small ruminants), should be studied. For example, new cattle or other livestock breeds may be less familiar to consumers, requiring new marketing strategies and approaches. 
In the longer term, we recommend convening a meeting of experts to discuss climate impacts on ruminant health in California, with possible participants such as the UC Davis School of Veterinary Medicine, UC Davis Department of Animal Science, California Cattlemen's Association, and California Woolgrowers. This could produce a report similar in scope to the present work.

\section{3) What are the abilities of different soil management strategies to increase the resilience of rangelands to climate change in California?}

\section{What we know:}

There is increasing interest in studying the role of rangeland soils in the provision of ecosystem services, and more specifically climate change mitigation and adaptation (Chambers et al. 2016; Derner et al. 2016). Early studies in California have shown that compost application on rangelands can increase soil carbon sequestration, forage productivity and water infiltration rates, which could help increase rangelands resilience to drought and extreme events (Ryals and Silver 2013). This approach is currently being scaled up in a study coordinated by the Marin Carbon Project $^{3}$ and USDA/NRCS, with 14 field sites up and down California (S. Vergara, pers. comm., 12 July 2017). This will help determine the robustness of these results under different climates and soil types, and quantify the potential for synergy between climate adaptation and climate mitigation on rangelands.

\section{What we don't know:}

Compost application effects could vary greatly by site, and compost could have undesirable effects on native plant diversity at some sites (Gravuer and Gunasekara 2016). Compost application may also cause water quality concerns in rangeland freshwater sources. Studies already underway will begin to answer some of these questions. More generally, long-term studies on the effects of rangeland management practices on soil health and implications for ecosystem services such as forage productivity, carbon sequestration, rangeland hydrology and species diversity are needed. In addition, much remains to be learned about the feasibility and applicability of such practices (for example, how to make compost rangeland application efficient for operators).

\section{4) What structural changes may occur within the California livestock industry as it adapts to climate change?}

\section{What we know:}

The economics of full-time ranching are already challenging in California, especially for small and medium-sized operations (Chapter 1). Beef prices and beef cattle populations in California already show considerable year-to-year variability, while sheep populations are fairly stable and

\footnotetext{
${ }^{3}$ http://www.marincarbonproject.org/marin-carbon-project-science
} 
goat populations are increasing (though much smaller to begin with). Climate change is likely to increase, not decrease, these economic stresses and vulnerabilities.

\section{What we don't know:}

How must the production year (season of calving, etc.) and time/location of forage adapt to climate change? For example, will demand for grazing on high-elevation public lands begin earlier in the spring, due to accelerated drying of foothill pastures? To what extent can interstate transport of cattle compensate for the expected greater variability of future California rainfall (and therefore variability of forage production)? Will stockers replace cow-calf production in California? If the state's cattle population declines overall due to decreased forage availability, how will this change the average size of ranching operations and the ranching demographic?

Research to understand the financial impacts of climate change to individual ranchers and to the ranching industry as a whole will be essential. Knowing the costs of different management strategies will help ranchers make optimal decisions as they adapt to climate change. For example, ranchers will need more information on diversification of ranching enterprises, including opportunities, strategies, and potential barriers (Brunson and Huntsinger 2008).

\section{5) How can social networks of California ranching communities more effectively disseminate climate adaptation information and assess rancher needs?}

\section{What we know:}

California rangelands are complex socio-ecological systems (Huntsinger and Oviedo 2014). They require multidisciplinary research that combines knowledge of the impacts of climate change with the costs and benefits of different adaptation strategies in order to increase ranchers' ability to manage effectively while maintaining their economic viability. California ranchers already have numerous strategies for coping with climate variability (Macon et al. 2016), and research on social networks will allow for more effective dissemination of these adaptation strategies.

\section{What we don't know:}

Much work remains to be done in applying economic and social science research to understand rancher perceptions, behavior, adaptation strategies, barriers, and communication strategies (Davidson 2016). The information needs to be available to ranchers at the appropriate scale: for example, specific to their county, their ranch size, and livestock type. Policy solutions are needed that allow ranchers to minimize risks, diversify operations, and increase water storage, while continuing to provide multiple ecosystem services. Partnerships that include producer organizations, academic institutions, government agencies, and non-profit organizations will be required.

\section{6) What new policies might aid climate change adaptation in California rangelands?}




\section{What we know:}

Policies can enable or hinder ranchers' ability to adapt to climate change. Policies for the protection of agricultural land such as the California Land Conservation Act (Williamson Act) have been effective in protecting rangeland habitats. The Sustainable Agricultural Lands Conservation Program ${ }^{4}$ funds conservation easements and links the protection and management of California's agricultural lands to greenhouse gas emissions reductions. In the near future, the program will also incentivize conservation practices that reduce emissions and increase carbon sequestration. In 2016, the state Legislature passed SB 859 to fund the Healthy Soils Program ${ }^{5}$, which provides funding, technical assistance, and outreach to producers to incentivize management practices that sequester carbon on farms and ranches.

\section{What we don't know:}

To help ranchers adapt to climate change, new and innovative policy solutions are needed that allow ranchers to minimize economic risks, allow income diversification, increase carbon sequestration, and improve on-farm water storage while continuing to provide other ecosystem services. More research is needed to shed light on ranchers' preferences for how these programs are implemented (direct payments, tax breaks, other incentives), what may encourage or discourage ranchers' participation, and how to efficiently conduct monitoring and verification.

\section{CONCLUSION}

Because approximately half of California's land area is rangelands, rangeland sustainability plays a key role in maintaining the health of the state's natural resource base. Though a changing climate is likely to exert stress on the productivity and viability of many California rangelands, trends in policy, such as the Healthy Soils Program, suggest growing recognition of the value of ecosystem services that wellmanaged rangelands provide.

California rangelands have a long history of

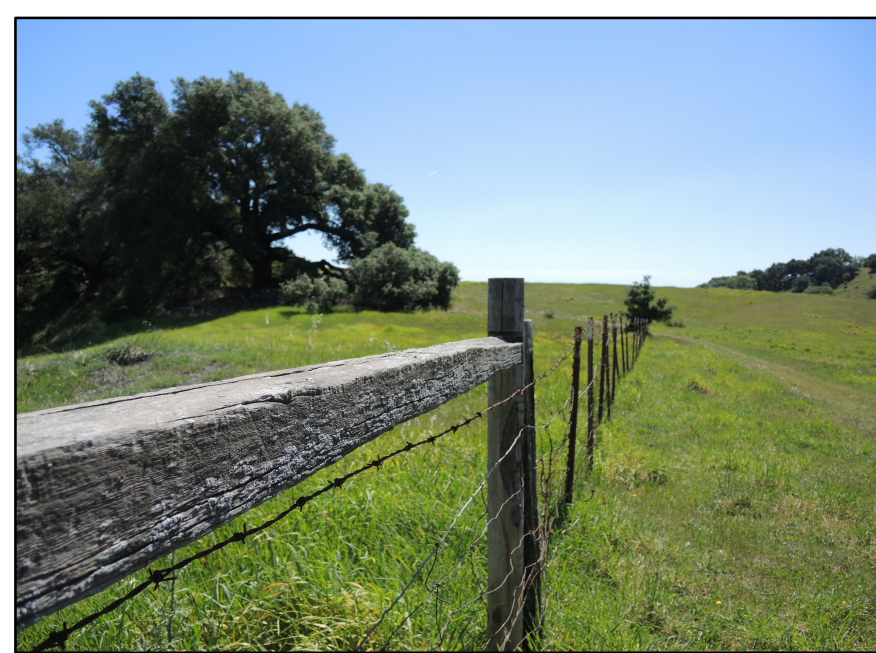

Pepperwood Preserve, Sonoma County, April 2015. (Photo by Amber Kerr.) withstanding physical, ecological, and economic changes. Careful management can help rangelands remain ecologically healthy and economically productive under future climate. Ranchers are already used to dealing with large year-to-year variability, and their long-term knowledge of their land will be a key ingredient in crafting climate adaptation plans that are locally appropriate. We hope that this report and future research efforts will help California

\footnotetext{
${ }^{4}$ http://www.conservation.ca.gov/dlrp/SALCP

${ }^{5}$ https://www.cdfa.ca.gov/oefi/healthysoils/HSInitiative.html
} 
rangelands maintain their important contributions to California's economy, biodiversity, and natural and cultural heritage. 


\section{REFERENCES}

Brunson, M.W. and L. Huntsinger. 2008. Ranching As A Conservation Strategy: Can Old Ranchers Save The New West? Rangeland Ecology \& Management 61:137-147.

Chambers A., R. Lal, and K. Paustian. 2016. Soil carbon sequestration potential of US croplands and grasslands: Implementing the 4 per Thousand Initiative. Journal of Soil and Water Conservation 71:68A-74A.

Chaplin-Kramer, R. and M. R. George. 2013. MR Effects of climate change on range forage production in the San Francisco Bay Area. PLoS One. 8:e57723.

Clements, D.R., and A. Ditommaso. 2011. Climate change and weed adaptation: can evolution of invasive plants lead to greater range expansion than forecasted? Weed Research 51:227240.

Davidson, D. 2016. Gaps in agricultural climate adaptation research. Nature Climate Change 6:433-435.

Derner, J.D., C. Stanley, and C. Ellis. 2016. Usable Science: Soil Health. Rangelands 38:64-67.

Gornish E. S., E. Brusati, and D. W. Johnson. 2016. Practitioner perspectives on using nonnative plants for revegetation. California Agriculture 70:194-199.

Gravuer, K. and A. Gunasekara. 2016. Compost Application Rates for California Croplands and Rangelands for a CDFA Healthy Soils Incentives Program. California Department of Food and Agriculture, Sacramento, CA, p. 24.

Havstad, K.M., J. R. Brown, R. Estell, E. Elias, A. Rango, and C. Steele. 2016. Vulnerabilities of Southwestern U.S. rangeland-based animal agriculture to climate change. Climatic Change.

Huntsinger, L. and J. L. Oviedo. 2014. Ecosystem Services are Social-Ecological Services in a Traditional Pastoral System: the Case of California's Mediterranean Rangelands. Ecology and Society 19.

Jones, A., K. Calvin and J.-F. Lamarque. 2016. Climate Modeling with Decision Makers in Mind. EoS. p.97.

Lemos, M.C., C. J. Kirchhoff, and V. Ramprasad. 2012. Narrowing the climate information usability gap. Nature Climate Change 2:789-794.

Macon, D. K., S. Barry, T. Becchetti, J. S. Davy, M. P. Doran, J. A. Finzel, H. George, J. M. Harper, L. Huntsinger, and R. S. Ingram. 2016. Coping With Drought on California Rangelands. Rangelands 38:222-228.

Nardone, A., B. Ronchi, N. Lacetera, M. S. Ranieri, and U. Bernabucci. 2010. Effects of climate changes on animal production and sustainability of livestock systems. Livestock Science 130:57-69.

Reeves, M. C. and K. E. Bagne. 2016. Vulnerability of cattle production to climate change on U.S. rangelands. U.S. Department of Agriculture, Forest Service, Rocky Mountain Research Station, Fort Collins, CO, p. 39.

Robison, R. 2009. Research Needs for Invasive Plants in California. California Invasive Plant Council, Berkeley, CA, p. 53. 
Ryals, R. and W. L. Silver. 2013. Effects of organic matter amendments on net primary productivity and greenhouse gas emissions in annual grasslands. Ecological Applications 23:46-59.

Scasta, J.D., D. L. Lalman, and L. Henderson. 2016. Drought Mitigation for Grazing Operations: Matching the Animal to the Environment. Rangelands 38:204-210.

Sharrow, S. 2000. Trees in pastures: Do cattle benefit from shade? Temperate Agroforester 8:1.

Stull, C, S. Barry, and W. Jensen. 2007. Beef Care Practices. UC Agriculture and Natural Resources, Oakland, CA, p. 38.

Suttle, K. B., M. A. Thomsen, and M. E. Power. 2007. Species interactions reverse grassland responses to changing climate. Science 315:640-642. 